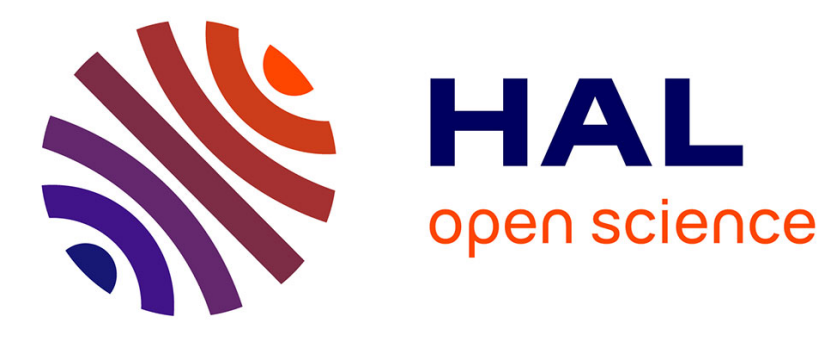

\title{
The nature of Earth's first crust
}

Richard Carlson, Marion Garçon, Jonathan O'neil, Jesse Reimink, Hanika Rizo

\section{To cite this version:}

Richard Carlson, Marion Garçon, Jonathan O'neil, Jesse Reimink, Hanika Rizo. The nature of Earth's first crust. Chemical Geology, 2019, 530, pp.119321. 10.1016/j.chemgeo.2019.119321 . hal-02344389

\section{HAL Id: hal-02344389 \\ https://hal.uca.fr/hal-02344389}

Submitted on 17 Nov 2020

HAL is a multi-disciplinary open access archive for the deposit and dissemination of scientific research documents, whether they are published or not. The documents may come from teaching and research institutions in France or abroad, or from public or private research centers.
L'archive ouverte pluridisciplinaire HAL, est destinée au dépôt et à la diffusion de documents scientifiques de niveau recherche, publiés ou non, émanant des établissements d'enseignement et de recherche français ou étrangers, des laboratoires publics ou privés. 


\title{
The Nature of Earth's First Crust
}

\author{
Richard W. Carlson \\ Department of Terrestrial Magnetism \\ Carnegie Institution for Science \\ 5241 Broad Branch Road, NW \\ Washington, DC 20015 USA \\ Marion Garçon \\ Laboratoire Magmas et Volcans \\ 6 Avenue Blaise Pascal, TSA 60026 \\ 63178 Aubiere Cedex, France \\ Jonathan O'Neil \\ Department of Earth and Environmental Sciences \\ University of Ottawa \\ Carleton-Ottawa Geoscience Centre \\ Ottawa, Ontario, Canada K1N 6N5 \\ Jesse Reimink \\ Department of Terrestrial Magnetism \\ Carnegie Institution for Science \\ 5241 Broad Branch Road, NW \\ Washington, DC 20015 USA \\ Hanika Rizo \\ Department of Earth Sciences \\ Carleton University \\ Carleton-Ottawa Geoscience Centre \\ Ottawa, Ontario, Canada K1S 5B6
}

Accepted for Chemical Geology

September 26, 2019 


\begin{abstract}
:
Recycling of crust into the mantle has left only small remnants at Earth's surface of crust produced within a billion years of Earth formation. Few, if any, of these ancient crustal rocks represent the first crust that existed on Earth. Understanding the nature of the source materials of these ancient rocks and the mechanism of their formation has been the target of decades of geological and geochemical study. This traditional approach has been expanded recently through the ability to simultaneously obtain $\mathrm{U}-\mathrm{Pb}$ age and initial $\mathrm{Hf}$ isotope data for zircons from many of these ancient, generally polymetamorphic, rocks. The addition of information from the short-lived radiometric systems ${ }^{146} \mathrm{Sm}-{ }^{142} \mathrm{Nd}$ and ${ }^{182} \mathrm{Hf}^{-182} \mathrm{~W}$ allows resolution of some of the ambiguities that have clouded the conclusions derived from the long-lived systems. The most apparent of these is clear documentation that Earth experienced major chemical differentiation events within the first tens to hundreds of millions of years of its formation, and that Earth's most ancient crustal rocks were derived from these differentiated sources, not from primitive undifferentiated mantle. Eoarchean rocks from the North Atlantic Craton and the Anshan Complex of the North China Craton have sources in an incompatible-elementdepleted mantle that dates to 4.4-4.5 Ga. Hadean/Eoarchean rocks from two localities in Canada show the importance of remelting of Hadean mafic crust to produce Eoarchean felsic crust. The mafic supracrustal rocks of the Nuvvuagittuq Greenstone Belt are a possible example of the Hadean mafic basement that is often called upon to serve as the source for the high-silica rocks that define continental crust. Many, but not all, ancient terranes show a shift in the nature of the sources for crustal rocks, and possibly the physical mechanism of crust production, between 3.0-3.6 Ga. This transition may reflect the initiation of modern plate tectonics. Eoarchean/Hadean rocks from some terranes, however, also display compositional characteristics expected for convergent margin volcanism suggesting that at least some convergent margin related magmatism began in the Hadean. The persistence of isotopic variability in ${ }^{142} \mathrm{Nd} /{ }^{144} \mathrm{Nd}$ into the mid-Archean, and the eventual reduction in that variability by the end of the Archean, provides new information on the efficiency by which mantle convection recombined the products of Hadean silicate-Earth differentiation. The rate of crust production and recycling in the Hadean/Archean, however, is not resolved by these data beyond the observation that extreme isotopic compositions, such as expected for Hadean evolved, continent-like, crust are not observed in the preserved Eoarchean rock record. The lack of correlation between ${ }^{142} \mathrm{Nd} /{ }^{144} \mathrm{Nd}$ and ${ }^{182} \mathrm{~W} /{ }^{184} \mathrm{~W}$ variation in Archean rocks suggests that these two systems track different processes; the Sm-Nd system mantle-crust differentiation while $\mathrm{Hf}$ $\mathrm{W}$ is dominated by core formation. The major silicate differentiation controlling $\mathrm{Sm} / \mathrm{Nd}$ fractionation occurred at $\sim 4.4 \mathrm{Ga}$, possibly as a result of the Moon-forming impact, after the extinction of ${ }^{182} \mathrm{Hf}$.
\end{abstract}




\section{1) Introduction}

Although we now know the age of the Solar System to four significant figures (e.g. Connelly et al., 2017), the precision of our understanding of the age of the Earth has advanced only marginally since the first applications of radiometric dating to the problem in the 1950 's (Patterson, 1956). The holdup is not due to a lack of chronometers appropriate for addressing this question, but instead the fact that the most ancient terrestrial differentiation events have been overprinted by the continuing geologic activity of the planet. Nowhere is this problem more obvious than in our understanding of the nature of Earth's first crustal rocks and the geologic processes that created them. Crustal rocks older than 3.6 Ga cover only a few parts per million of the current Earth's surface area. A small area of the Slave Craton of the Northwest Territories of Canada extends the rock record to 4.02-4.03 Ga (Bowring and Williams, 1999; Reimink et al., 2016b), but past that, samples are limited to a still disputed ${ }^{146} \mathrm{Sm}-{ }^{142} \mathrm{Nd}$ whole rock isochron age of $4.28 \mathrm{Ga}$ for about $6 \mathrm{~km}^{2}$ of mafic metamorphic rocks along the shores of Hudson Bay (O'Neil et al., 2008; 2012), and xenocrystic or detrital zircons, the oldest of which are $4.37 \mathrm{Ga}$ from western Australia (Valley et al., 2014). All of these ages are surprisingly young compared to the $4.567 \mathrm{Ga}$ age of the Solar System and the expectation that most of Earth's mass was accreted within a few tens of million years (Wetherill, 1990).

None of the rocks available on Earth's surface today are obviously representatives of the first crust to form on Earth, furthermore, our expectations of what that first crust may have looked like are also limited. The oldest crust on the Moon consists of anorthosite that formed during crystallization of the lunar magma ocean (e.g. Wood et al., 1970; Borg et al., 2011). If Earth also experienced magma ocean episodes during its formation, there is no reason to expect the formation of a thick terrestrial anorthositic crust. Plagioclase saturation in a terrestrial magma ocean would be suppressed by early crystallization of other, higher-pressure, aluminous phases, such as garnet, as well as the role water plays in delaying plagioclase crystallization (ElkinsTanton, 2011). A quench crust on Earth's magma ocean would have been peridotitic and hence buoyantly unstable with respect to the liquid peridotite mantle below it. If the terrestrial magma ocean evolved to a late-stage incompatible-element-rich liquid, analogous to the lunar KREEP component (Warren and Wasson, 1979), the evidence for such material is not preserved in any modern or ancient terrestrial rock. Given that Earth likely had non-negligible water contents when it formed, the residual liquid from magma ocean crystallization could have been compositionally similar to the Si-rich rocks that dominate Earth's most ancient preserved crust (Harrison, 2009; Bell et al., 2014). None of the oldest terrestrial rocks, however, have isotopic compositions consistent with them, or their progenitors, forming within tens of million years after Earth's formation.

The survival of Earth's first crust likely was challenging. Given the rate of bombardment of Earth's surface during the latter stages of planetary accretion, a possible outcome is that Earth's surface would have been continually destroyed by impacts (Marchi et al., 2014). Indeed, the dearth of terrestrial rocks older than $3.9 \mathrm{Ga}$ was once proposed to reflect the violent resurfacing of Earth due to a period of intense meteorite bombardment that is recorded on the Moon (Tera et al., 1974; Kring and Cohen, 2002). Whether there was such a "late heavy 
bombardment", however, has been called into question on the basis of expanded lunar crater chronology datasets (e.g. Zellner, 2017; Norman, 2019). In addition, the increasing appearance, though still very small in volume, of rocks and minerals older than $4 \mathrm{Ga}$, along with the lack of evidence for impact shock in most of these ancient zircons (Cavosie et al., 2019), weakens the case that the impact flux prior to $3.8 \mathrm{Ga}$ was sufficient to completely destroy preexisting crust.

Plate tectonics is an efficient mechanism for returning crust into Earth's interior, but, as will be discussed later, the debate continues regarding when plate subduction started on Earth. While Earth may have started in a stagnant-lid tectonic mode (e.g. Solomatov and Moresi, 1996; Debaille et al., 2013) that would have helped preserve whatever crust existed at that time, a mobile-lid regime also is possible (Foley and Rizo, 2017). Crustal destruction by impacts and recycling by plate tectonics both would have worked to delay the beginning of crust preservation until the time when the impact flux declined to the point that it no longer drove resurfacing of the whole planet, or continental blocks grew big enough to become stable buoyant cratons.

Although few, if any, of even the most ancient rocks on Earth were created during its formative period, there are avenues currently being pursued that provide information about the history and nature of the material that melted to form Earth's oldest preserved crust. This paper focuses on two such avenues: the improved ability to determine accurate initial Hf isotopic compositions of ancient rocks through combined $\mathrm{Hf}$ and $\mathrm{U}-\mathrm{Pb}$ isotope analysis of the zircons some of them contain, and the application of the short-lived radioactive systems ${ }^{146} \mathrm{Sm}-{ }^{142} \mathrm{Nd}$ and ${ }^{182} \mathrm{Hf}-{ }_{-}^{182} \mathrm{~W}$ that are sensitive only to those differentiation events that occurred in the first tens to hundreds of million years of Earth history. The developing story from these approaches is revealing the major differentiation events that accompanied Earth formation, but also the possibility of a late, circa $4.4 \mathrm{Ga}$, "resetting" of the outer portions of the planet via the Moonforming impact, and a diachronous change in the source materials and processes involved in creating the first long-lived crust on Earth.

\section{2) The Rock Record}

Earth's surface currently includes about 35 crustal fragments dating to $2.5 \mathrm{Ga}$ or older (Bleeker, 2003) that together constitute about $2.9 \%$ of the present Earth's surface (Goodwin, 1996). Only small fractions of some of these ancient cratons contain rocks older than $3.5 \mathrm{Ga}$ and only a very small area of the Slave Craton (currently mapped as $<<1 \mathrm{~km}^{2}$; (Reimink et al., 2016a)) contains rocks as old as 4.02-4.03 Ga. Regions of crust with rocks as old as 3.8 to $3.9 \mathrm{Ga}$ are found in southwestern Greenland (Nutman et al., 1997; Nutman et al., 2013), northern Labrador (Collerson and Bridgewater, 1979; Shimojo et al., 2016; Vezinet et al., 2018), northeastern Canada (O'Neil et al., 2013), eastern Antarctica (Black et al., 1986; Kusiak et al., 2014), and central China (Liu et al., 2008). Excellent summaries of the geology of most of these ancient terranes are presented in the book "Earth's Oldest Rocks" (Van Kranendonk et al., 2019).

FIGURE 1 HERE 
The oldest known terrestrial materials are individual zircon grains recovered from a circa $3 \mathrm{Ga}$ quartzite in the Yilgarn Craton of western Australia (Fig. 1) (Froude et al., 1983; Harrison, 2009; Cavosie et al., 2019) where the current consensus for the oldest reliable age is $4.37 \mathrm{Ga}$ (Valley et al., 2014). Other occurrences of Hadean zircons include a single $4.2 \mathrm{Ga}$ core within a zircon from the Acasta gneiss of the Slave Craton, Canada (lizuka et al., 2006), 4.15 Ga detrital zircons from a sandstone in the Barberton Greenstone Belt of the Kaapvaal Craton, southern Africa (Byerly et al., 2018), 4.1 Ga zircons from the Sao Francisco Craton, Brazil (Paquette et al., 2015), in Paleozoic quartzites from the Cathaysia Block, China (Xing et al., 2014), and as xenocrysts in an Ordovician volcanic rock from the North Qinling orogenic belt of China (Liang et al., 2007) that have $\mathrm{Hf}$ model ages up to $4.45 \mathrm{Ga}$ (Diwu et al., 2013), 3.98 Ga zircons from Enderby Land, Antarctica (Belyatsky et al., 2011), and $3.96 \mathrm{Ga}$ zircons in an Archean quartzite from the Beartooth Mountains of Montana (Mueller et al., 1992). With the exception of the Acasta and Antarctic gneisses, the source rocks for these zircons are gone, nevertheless, chemical, isotopic, and mineral inclusion studies of the zircons from western Australia suggest an origin in granitoid rocks generated by relatively low temperature melting of water-rich source rocks (Cavosie et al., 2005; Watson and Harrison, 2005; Hopkins et al., 2008). In that sense, these zircons most likely crystallized in intermediate to silicic igneous rocks similar to the tonalitetrondhjemite-granodiorite (TTG) suites that constitute the main mass of most Archean igneous terranes (Hoffmann et al., 2019). Most petrogenetic models for TTGs suggest that they cannot be generated by the melting of peridotite, but instead are partial melts of mafic source rocks (e.g. Moyen and Martin, 2012). Abundant mafic rocks, now variably metamorphosed, are the second component of the classic Archean granite-greenstone terrane, where "granite" is used as a broad term that includes the whole TTG compositional spectrum, and "greenstone" is a general term for the metamorphosed mafic/ultramafic rocks.

\section{3) Isotopic Tools to Study the Nature of the First Crust}

\section{1) Long-lived radionuclides and the use of combined U-Pb and $\mathrm{Hf}$ isotope analyses of zircon}

Advances in zircon $\mathrm{U}-\mathrm{Pb}$ geochronology have made this technique the tool of choice for determining the igneous age of ancient rocks. The main drawback to the approach is that zircons do not occur in all rock types, so the geochronology of the sometimes-large mafic component of granite-greenstone terranes is nowhere near as well developed as for the "granite" component. Constraining the age of the mafic rocks directly derived from the mantle therefore often relies on the field interpretation of their relationship to the zircon-bearing felsic rocks, which is often equivocal in ancient, typically highly deformed, terranes. Because the felsic crust is likely derived from melting of an older mafic precursor, poor geochronological constraints on the mafic/ultramafic lithologies represent a considerable challenge to the study of Earth's first crust. The combination of $\mathrm{Hf}$ isotope determinations with $\mathrm{U}-\mathrm{Pb}$ age measurements in the same zircon has dramatically expanded the traditional use of the initial isotopic composition of rocks to determine the nature of their protoliths. A key goal of such studies is to define whether the rocks were produced by reworking of older crustal rocks or instead are relatively new additions to the continental crust from the mantle (e.g. Armstrong et al., 1977; Hawkesworth and Kemp, 2006; Dhuime et al., 2012). For polymetamorphic Eoarchean 
or Hadean rocks, obtaining accurate initial isotopic compositions for long-lived radioactive systems (Rb-Sr, ${ }^{147} \mathrm{Sm}-{ }^{143} \mathrm{Nd}$, Lu-Hf and $\mathrm{U}-\mathrm{Th}-\mathrm{Pb}$ ) is made difficult as a result of possible changes to the parent/daughter ratio of the rock during a metamorphic event that occurs long after the igneous origin of the sample.

Because the variability in isotopic composition in these systems often is small, the initial isotopic ratios are usually expressed as differences from values measured for a terrestrial standard material that is assumed in many, but not all, cases to approximate the isotopic composition of the Bulk Silicate Earth (BSE). For the Lu-Hf and ${ }^{147} \mathrm{Sm}-{ }^{143} \mathrm{Nd}$ systems, because both parent and daughter elements are refractory lithophile elements, the BSE values used here are taken from values measured for chondritic meteorites (Bouvier et al., 2008). For the ${ }^{146} \mathrm{Sm}-{ }^{142} \mathrm{Nd}$ system, the reference BSE value currently is not accurately determined because different meteorites show differences in ${ }^{142} \mathrm{Nd} /{ }^{144} \mathrm{Nd}$ that reflect imperfect mixing of the various nucleosynthetic contributions to the element inventory in the Solar System (e.g. Qin and Carlson, 2016). For this reason, the normalizing value for ${ }^{142} \mathrm{Nd} /{ }^{144} \mathrm{Nd}$ is the isotopic composition measured for a terrestrial Nd standard, for example JNdi-1 (Tanaka et al., 2000). Similarly, $\mathrm{W}$ isotopic compositions are commonly reported to a W solution standard prepared from W metal. Neither JNdi nor the W metal standards necessarily have isotopic compositions identical to the BSE. Initial isotopic compositions are usually reported in epsilon or mu units using the equations:

$$
\begin{aligned}
\varepsilon^{143} N d & =\left(\frac{\left(\frac{{ }^{143} N d}{{ }^{144} N d}\right) \text { Sample }}{\left(\frac{{ }^{143} N d}{{ }^{144} N d}\right) B S E}-1\right) \times 10,000 \\
\varepsilon H f & =\left(\frac{\left(\frac{{ }^{176} H f}{{ }^{177} H f}\right) \text { Sample }}{\left(\frac{{ }^{176} H f}{{ }^{177} H f}\right) \text { BSE }}-1\right) \times 10,000 \\
\mu^{142} N d= & \left(\frac{\left(\frac{{ }^{142} N d}{{ }^{144} N d}\right) \text { Sample }}{\left(\frac{{ }^{142} N d}{{ }^{144} N d}\right) \text { Standard }}-1\right) \times 1,000,000 \\
\mu^{182} W= & \left(\frac{\left(\frac{{ }^{182} W}{184}\right) \text { Sample }}{\left(\frac{182}{184}\right) \text { Standard }}\right) \times 1,000,000
\end{aligned}
$$


The $\mathrm{Lu} / \mathrm{Hf}$ ratios of zircons are very low because in zircon $\mathrm{Hf}$ is a minor element, while $\mathrm{Lu}$ is a trace element. Slow diffusion of elements through the zircon crystal lattice leads the Hf isotopic composition of zircon to be less sensitive to metamorphic changes in parent/daughter ratios than are whole rock measurements. Nevertheless, recrystallization or new overgrowths of the zircon during metamorphism, or use of an incorrect $\mathrm{U}-\mathrm{Pb}$ age due to disturbance of the $\mathrm{U}-\mathrm{Pb}$ systematics of the zircon to calculate its initial $\varepsilon \mathrm{Hf}$ all potentially compromise the accuracy of initial $\mathrm{Hf}$ isotope determinations using zircon. This is particularly the case for detrital zircons where ancient $\mathrm{Pb}$-loss can lead to concordant "apparent" ${ }^{207} \mathrm{~Pb} /{ }^{206} \mathrm{~Pb}$ ages that are younger than the true zircon crystallization ages (Vervoort and Kemp, 2016).

\section{2) The role of short-lived radionuclides}

Short-lived radionuclides, such as the $103 \mathrm{Ma}$ half-life (Marks et al., 2014) decay of ${ }^{146} \mathrm{Sm}$ to ${ }^{142} \mathrm{Nd}$ or the $8.9 \mathrm{Ma}$ half-life (Vockenhuber et al., 2004) decay of ${ }^{182} \mathrm{Hf}$ to ${ }^{182} \mathrm{~W}$ provide new avenues to constrain the information obtained from long-lived radiometric systems concerning the chemical evolution of the source materials of any given rock sample. Given current isotope ratio measurement precision and the magnitude of parent/daughter fractionation in these systems, decay of the parent isotope can only detectably change the isotopic composition of the daughter element for of order 5 half-lives of the parent, so $\sim 500 \mathrm{Ma}$ for ${ }^{146} \mathrm{Sm}$ and $\sim 50 \mathrm{Ma}$ for ${ }^{182} \mathrm{Hf}$ (Fig. 2). Isotopic variability in the daughter element of such systems can only be created by differentiation events that cause parent/daughter elemental fractionation within these time intervals when the parent isotope is still in sufficient abundance to affect the abundance of the daughter isotope. The isotopic variability in the daughter element in the mantle, once created, can be either reduced or enhanced by mixing with isotopically distinct materials at any time during Earth history, but the presence of isotopic variability in these daughter elements must reflect Hadean differentiation events.

\section{FIGURE 2 HERE}

Figure 3 illustrates the important advance allowed by combining initial $\mathrm{Hf}$ (or ${ }^{143} \mathrm{Nd}$ ) isotopic compositions with information from the ${ }^{146} \mathrm{Sm}-{ }^{142} \mathrm{Nd}$ system. In the model shown in figure $3, \mathrm{a}$ sample's zircons provide an $\varepsilon \mathrm{Hf}=-5$ at the $3.8 \mathrm{Ga}$ crystallization age of the rock (Fig. 3a). The negative initial $\varepsilon \mathrm{Hf}$ of the rock indicates that it was derived from a protolith that had a subchondritic Lu/Hf ratio. Defining the composition and age of the protolith, however, requires knowledge of the protolith's Lu/Hf ratio, which cannot be independently determined. The negative initial $\varepsilon \mathrm{Hf}$ of this rock thus may reflect genesis of the rock either by remelting of a relatively young, highly compositionally evolved (e.g. trondhjemitic) protolith, or an older, less evolved (e.g. basaltic) protolith. These two possible protoliths, however, will evolve dramatically different $\mu^{142} \mathrm{Nd}$, with a very low value expected for the older protolith, even if that protolith has only a moderately subchondritic Sm/Nd ratio (Fig. 3b). Including ${ }^{147} \mathrm{Sm}-{ }^{143} \mathrm{Nd}$ into this model shows the old $(4.56 \mathrm{Ga})$ basaltic protolith would have an $\varepsilon^{143} \mathrm{Nd}=-2.6$ at $3.8 \mathrm{Ga}$ while the younger $(4.17 \mathrm{Ga})$ trondhjemitic protolith would have an $\varepsilon^{143} \mathrm{Nd}=-4.6$ at $3.8 \mathrm{Ga}$. The 
reversal compared to ${ }^{142} \mathrm{Nd}$ of whether the basaltic or trondhjemitic protolith has the less radiogenic initial isotopic composition reflects the dominant effect of the parent-daughter ratio over protolith age for the long-lived ${ }^{147} \mathrm{Sm}-{ }^{143} \mathrm{Nd}$ system. In contrast, the short-lived ${ }^{146} \mathrm{Sm}-{ }^{142} \mathrm{Nd}$ system is more sensitive to protolith age, but only in the short time window prior to $\sim 4.0 \mathrm{Ga}$ when ${ }^{146} \mathrm{Sm}$ is extant. A similar application of paired isotope systems with varying half-lives has long been utilized in the U-Pb system, which is a part of what makes it such a reliable chronometer. Unlike the ${ }^{238,235} \mathrm{U}-{ }^{206,207} \mathrm{~Pb}$ systems, the $\mathrm{Sm}-\mathrm{Nd}$ and Lu-Hf systems have chemical behaviors somewhat distinct from one another, though the $\mathrm{Lu} / \mathrm{Hf}$ and $\mathrm{Sm} / \mathrm{Nd}$ ratios often are correlated. The paired use of these systems is most reliably brought to bear on Eoarchean felsic rocks, where initial $\varepsilon \mathrm{Hf}$ values can be accurately determined from magmatic zircons, and the whole-rock $\mu^{142} \mathrm{Nd}$ values are unlikely to be overprinted. The addition of ${ }^{142} \mathrm{Nd}$ data for ancient rocks thus provides a new window into refining the composition and age of the protolith of Earth's first preserved crustal rocks. Because of its short half-life, the ${ }^{146} \mathrm{Sm}-{ }^{142} \mathrm{Nd}$ system is particularly good at revealing truly ancient, e.g. $>4 \mathrm{Ga}$, crust-mantle differentiation events. Terrestrial variability in ${ }^{142} \mathrm{Nd} /{ }^{144} \mathrm{Nd}$ was first reported over 25 years ago (Harper and Jacobsen, 1992), but it was not until 2003 when the precision of these measurements moved beyond the simple detection of variation into the use of this system as a tracer for Hadean differentiation events on Earth (Boyet et al., 2003; Caro et al., 2003). Since then, the number of Archean/Hadean terranes where both zircon initial Hf isotopic data and ${ }^{142} \mathrm{Nd} /{ }^{144} \mathrm{Nd}$ data are available has grown considerably.

\section{FIGURE 3 HERE}

Figure 4 shows an example of how the combination of these two systems can provide quantitative information regarding the Hadean history of Earth from the extant Eoarchean rock record. Assuming the $\mathrm{Hf}$ and $\mathrm{Nd}$ isotope systems have a shared prehistory, paired $\mathrm{Sm} / \mathrm{Nd}$ and $\mathrm{Lu} / \mathrm{Hf}$ source ratios can be derived, assuming the same model age for the differentiation event that changed these parent/daughter ratios. Figure 4 shows the results of these calculations for the two hypothetical rocks outlined in Figure 3 (at $3.8 \mathrm{Ga} \varepsilon \mathrm{Hf}=-5$ and $\mu^{142} \mathrm{Nd}=-10$ and -40 ).

\section{FIGURE 4 HERE}

Another short-lived radioactive isotope system that is seeing increasing use in the study of early Earth differentiation is the ${ }^{182} \mathrm{Hf}_{-}{ }^{182} \mathrm{~W}$ system. Like the $\mathrm{Sm}-\mathrm{Nd}$ system, partial melting or fractional crystallization can fractionate the $\mathrm{Hf} / \mathrm{W}$ ratio, as $\mathrm{W}$ is substantially more incompatible than $\mathrm{Hf}$ in these processes (Shearer and Righter, 2003). Because the daughter element is the more incompatible of the pair, silicate differentiation processes occurring while both parents are still extant should result in positive correlations between ${ }^{142} \mathrm{Nd} /{ }^{144} \mathrm{Nd}$ and ${ }^{182} \mathrm{~W} /{ }^{184} \mathrm{~W}$. Given the large difference in the half-lives of these two systems, however, if the differentiation event occurred after the extinction of ${ }^{182} \mathrm{Hf}(\sim 4.5 \mathrm{Ga})$, but before the extinction of ${ }^{146} \mathrm{Sm}(\sim 4.0 \mathrm{Ga})$ the event would create materials that would evolve distinct ${ }^{142} \mathrm{Nd} /{ }^{144} \mathrm{Nd}$, but not ${ }^{182} \mathrm{~W} /{ }^{184} \mathrm{~W}$. Another important difference between these two systems is that the Hf-W system is sensitive to metal-silicate fractionation as $\mathrm{W}$ is a moderately siderophile element while $\mathrm{Hf}$ is strictly lithophile. In contrast, Sm and $\mathrm{Nd}$ are both lithophile, at least under the oxidizing conditions of 
the present Earth's crust and mantle (Wohlers and Wood, 2017), and thus are not fractioned by core-formation. When used in conjunction with ${ }^{146} \mathrm{Sm}^{-142} \mathrm{Nd}$, the $\mathrm{Hf}-\mathrm{W}$ system potentially allows resolution of whether the events recorded by the systems track early silicate differentiation or instead core-mantle separation. Both the high $\mathrm{W}$ concentration in chondritic meteorites and their large difference in $\mu^{182} \mathrm{~W}$ compared to Earth's mantle (e.g. Kleine et al., 2009) also makes the $W$ isotopic composition a sensitive recorder of the addition of chondritic material to an already differentiated Earth, but such addition will have little or no effect on the Sm-Nd system.

\section{4) Observations from a Selection of Archean/Hadean Terranes}

\section{1) North Atlantic Craton}

\subsection{1) Southwest Greenland}

The ancient rocks of southwest Greenland, in the North Atlantic Craton (Fig. 1), were among the first to provide Eoarchean ages extending the rock record to before $3.5 \mathrm{Ga}$ (Black et al., 1971; Badsgaard, 1973), and they were the first to show resolvably high ${ }^{142} \mathrm{Nd} /{ }^{144} \mathrm{Nd}$ (Harper and Jacobsen, 1992; Boyet et al., 2003; Caro et al., 2003) and ${ }^{182} \mathrm{~W} /{ }^{184} \mathrm{~W}$ (Willbold et al., 2011; Rizo et al., 2016; Dale et al., 2017) compared to modern terrestrial rocks. They remain an important source of information about the ancient crust as they contain both the typical "grey gneiss" terranes found in most Archean cratons, but also a large and reasonably well-preserved unit of supracrustal rocks. Given the importance that mafic rocks play as potential sources for the parental melts of Archean TTG suites, the combination of felsic gneisses and mafic supracrustal rocks in SW Greenland provides an opportunity to examine this relationship with rocks of similar age. The $\mathrm{Nd}$ and $\mathrm{Hf}$ isotopic characteristics of these rocks have been studied extensively (Blichert-Toft et al., 1999; Vervoort and Blichert-Toft, 1999; Frei et al., 2004; Boyet and Carlson, 2006; Caro et al., 2006; Bennett et al., 2007; Hiess et al., 2009; Hoffmann et al., 2010, 2011a,b; Rizo et al., 2011, 2013; Naerra et al., 2012; O'Neil et al., 2016; Fisher and Vervoort, 2018; Saji et al., 2018; Kemp et al., 2019).

The ancient rocks of Greenland have been a particular focus for the interpretation of initial $\mathrm{Hf}$ isotopic compositions measured in zircons (Hiess et al., 2009; Fisher and Vervoort, 2018; Kemp et al., 2019). One of the purported advantages of using zircon to determine initial $\mathrm{Hf}$ isotopic compositions is that the approach minimizes the consequences of metamorphic disturbances to the whole rock parent/daughter ratios that would result in the calculation of erroneous initial isotopic compositions. The data for Greenland (Fig. 5a) do indeed show the zircon initial Hf isotope data to cluster more tightly than data for mafic whole rocks, although most of the range to positive $\mathrm{\varepsilon Hf}$ in the mafic rocks is shown by the boninitic composition rocks of the Garbenschiefer unit in the Isua Supracrustal Belt (ISB) (Polat et al., 2002; Hoffmann et al., 2010). In contrast, the initial Hf isotopic compositions determined for Eoarchean Greenland TTG whole rocks (Blichert-Toft et al., 1999; Vervoort and Blichert-Toft, 1999; Hoffmann et al., 2011a) overlaps substantially with the zircon data. 
A potentially more interesting observation is that the zircon and felsic whole rock $\mathrm{Hf}$ data for Eoarchean rocks from Greenland scatter about an $\varepsilon \mathrm{Hf}$ value near zero while the $\mathrm{Nd}$ isotope data, on average, plot at positive $\varepsilon^{143} \mathrm{Nd}$ (Fig. 5b). In contrast, most modern and many ancient igneous rocks show $\varepsilon^{143} \mathrm{Nd}$ and $\varepsilon \mathrm{Hf}$ to correlate roughly along a trend described by:

$$
\varepsilon H f=1.55 \times \varepsilon^{143} N d+1.21
$$

(Vervoort et al., 2011). This apparent decoupling of Hf and Nd isotopic composition (Fisher and Vervoort, 2018; Kemp et al., 2019) may well be unique to the Greenland Eoarchean rocks, and it may not be universally true even in Greenland as the data for the boninitic composition rocks of the Garbenschiefer unit extend to high positive $\varepsilon \mathrm{Hf}$ values in spite of the clustering of their $\varepsilon^{143} \mathrm{Nd}$ values within the range of other Greenland Eoarchean rocks (Fig. 5a,b). The Garbenschiefer data thus fall close to, or above, the Hf-Nd correlation seen in modern rocks, whereas the data for other Greenland Eoarchean rocks scatter towards positive $\varepsilon^{143} \mathrm{Nd}$ at nearly invariant $\varepsilon \mathrm{Hf}$ near zero (Fig. 6). While the large range in initial $\varepsilon \mathrm{Hf}$ of the Garbenschiefer metamafic rocks may reflect the sensitivity of the Lu-Hf system to metamorphic disturbance of Lu/Hf ratios in Mg-rich rocks, Hoffmann et al. (2010) suggest instead that the extension to very positive initial $\varepsilon \mathrm{Hf}$ reflects the contribution of an ancient highly incompatible element depleted component to the boninitic composition rocks of the Garbenschiefer unit. An important observation on this point is that Hoffmann et al. (2014) showed that rocks with similar composition to the ISB boninites are unlikely to be the source rocks for Greenland TTG's. In contrast, the ISB tholeiites have the right chemical compositions to serve this role. This means that the wide range of $\varepsilon \mathrm{Hf}$ of the boninites would not be expected to be expressed in the TTGs, and it is not (e.g. Fig. 5a). Given that the ISB boninites are not distinctive in the magnitude of their positive $\mu^{142} \mathrm{Nd}$ (O'Neil et al., 2016) compared to other Greenland Eoarchean rocks, the likely explanation of their extreme $\varepsilon \mathrm{Hf}$ values is that the source of the boninitic rocks experienced high degrees of melt depletion within only a few hundred million years prior to the extrusion of the boninitic lavas. An analogous explanation was provided for the very high initial $\varepsilon \mathrm{Hf}$ of the extremely incompatible element depleted Commendale komatiites from the eastern Kaapvaal craton (Hoffmann and Wilson, 2017).

\section{FIGURE 5 HERE}

\section{FIGURE 6 HERE}

The broadly chondritic initial $\varepsilon \mathrm{Hf}$ of the majority of Greenland Eoarchean zircons stands in contrast to the predominantly superchondritic initial $\varepsilon^{143} \mathrm{Nd}$ of samples from the same area (Fig. $5 b)$, though there is a considerable degree of scatter in the $\mathrm{Nd}$ data at all ages. Although the exact isotopic evolution of the incompatible element depleted mantle that is the source of modern mid-ocean ridge basalts (MORB), which we will refer to throughout this paper as "Depleted Mantle" (DM), is not known, assuming that the DM was formed close to the age of the Solar System would require a ${ }^{147} \mathrm{Sm} /{ }^{144} \mathrm{Nd}$ near 0.21 to evolve to an $\varepsilon^{143} \mathrm{Nd}$ value of +8 today (Fig. 5b), similar to the average value for modern MORB (Gale et al., 2013). For the Greenland 
$\varepsilon^{143} \mathrm{Nd}$ data, this DM line passes through the middle of the data cluster (Fig. 5b). To reach the higher values of initial $\varepsilon^{143} \mathrm{Nd}$ requires a source with higher $\mathrm{Sm} / \mathrm{Nd}$ that would result in present day ${ }^{143} \mathrm{Nd} /{ }^{144} \mathrm{Nd}$ higher than observed in MORB. As $\mathrm{Hf}$ and $\mathrm{Nd}$ isotopic variation are strongly coupled in both modern and many ancient rocks (Vervoort et al., 1996), the lack of coupling of these two systems in the Eoarchean rocks from Greenland has been used to suggest either that the Sm-Nd systematics in the felsic rocks are unreliable because they are controlled by accessory minerals (Kemp et al., 2019) or that the sources of the Greenland rocks were formed by differentiation that occurred at lower mantle pressures during crystallization of a terrestrial magma ocean (Caro et al., 2005; Hoffmann et al., 2011b; Rizo et al., 2011). Under these high pressure conditions, crystallization of phases such as bridgemanite and Ca-perovskite, that fractionate Lu-Hf and Sm-Nd differently than most upper mantle phases (Kato et al., 1988; Corgne et al., 2005), would lead to decoupled $\mathrm{Nd}$ and $\mathrm{Hf}$ isotope evolution. As with the Hf data, the initial $\varepsilon^{143} \mathrm{Nd}$ data for the Greenland rocks show little correlation with age of the samples, though there is some suggestion in the data for declining initial $\varepsilon^{143} \mathrm{Nd}$ with age (Fig. 5b) at a rate consistent with evolution of the oldest samples with ${ }^{147} \mathrm{Sm} /{ }^{144} \mathrm{Nd}$ of about 0.17 , a value more typical of mafic than felsic rocks. This could imply that the younger samples in the Greenland crust derive from, or were contaminated by, the older crust existing in the area, or alternatively that the mantle sources of their progenitor mafic magmas were contaminated by fluids/magmas (e.g. Hoffmann et al., 2011a) derived from recycled felsic sediments as occurs in modern subduction settings.

Support for the involvement of source rocks with superchondritic Sm/Nd ratios, needed to explain the positive initial $\varepsilon^{143} \mathrm{Nd}$ of the majority of Greenland Eoarchean samples, is provided by the extensive data now available for ${ }^{142} \mathrm{Nd} /{ }^{144} \mathrm{Nd}$ ratios in these rocks (Boyet and Carlson, 2006; Caro et al., 2006; Bennett et al., 2007; Rizo et al., 2011, 2012, 2013, 2016; O'Neil et al., 2016; Saji et al., 2018). By far the majority of Eoarchean samples from Greenland plot to positive $\mu^{142} \mathrm{Nd}$, indicative of sources that had superchondritic $\mathrm{Sm} / \mathrm{Nd}$ ratios since the early Hadean (Fig. $5 \mathrm{c}$ ). Unlike the case for $\varepsilon \mathrm{Hf}$, the $\mu^{142} \mathrm{Nd}$ of the boninitic rocks of the Garbenschiefer unit and other Greenland mafic rocks show a similar range of values. The $\mu^{142} \mathrm{Nd}$ data for both mafic and felsic rocks overlap substantially, consistent with the idea that the felsic rocks formed from similar source rocks as the mafic rocks, or that the felsic rocks are melts of the Eoarchean mafic basement of Greenland from which they inherited positive $\mu^{142} \mathrm{Nd}$.

By 3.8-3.9 Ga, ${ }^{146} \mathrm{Sm}$ is effectively extinct, so no additional evolution of ${ }^{142} \mathrm{Nd} /{ }^{144} \mathrm{Nd}$ would be expected in mafic rocks $<4 \mathrm{Ga}$. To reach the highest reported $\mu^{142} \mathrm{Nd}$ for the Greenland rocks (Fig. 5c) would require a ${ }^{147} \mathrm{Sm} /{ }^{144} \mathrm{Nd}$ of 0.21 in a material formed simultaneously with Earth formation at $4.56 \mathrm{Ga}$, or 0.24 in a source formed as late as $4.4 \mathrm{Ga}$, a time that may mark the Moon-forming impact and a resetting of much of Earth's isotope systematics (e.g. Carlson et al., 2015). The ${ }^{147} \mathrm{Sm} /{ }^{144} \mathrm{Nd}$ ratio of 0.24 would evolve $\varepsilon^{143} \mathrm{Nd}$ values similar to the higher values measured for the Greenland rocks (Fig. 5c). The two Sm-Nd decay schemes thus are in accord with the source materials of at least some of the Greenland rocks forming during a differentiation event at circa 4.4-4.5 Ga (Caro et al., 2005; Rizo et al., 2013; Saji et al., 2018). An important point to keep in mind with $\mu^{142} \mathrm{Nd}$ data is that typical measurement precisions are on 
the order of \pm 5 , so a large fraction of the apparent range in the data shown in figure $5 c$ may simply reflect scatter due to analytical uncertainty.

The ${ }^{143} \mathrm{Nd}$ and ${ }^{142} \mathrm{Nd}$ data for Greenland rocks thus indicate that the source materials that melted to create these preserved rocks formed in the first couple of hundred million years of Earth history and were characterized by superchondritic Sm/Nd ratios, a typical sign of an incompatible element depleted material. Although the positive initial $\varepsilon^{143} \mathrm{Nd}$ of the Greenland Eoarchean rocks has been suggested to reflect later metamorphic changes to the rock's Sm/Nd ratio that did not affect zircon Lu-Hf systematics (Vervoort and Kemp, 2016), the concordance of the positive $\varepsilon^{143} \mathrm{Nd}$ and $\mu^{142} \mathrm{Nd}$ suggest instead that the near zero $\varepsilon \mathrm{Hf}$ values for these rocks are the anomaly. If so, then the near-chondritic $\varepsilon \mathrm{Hf}$ of the Greenland zircons could reflect: 1 ) evolution of the protolith of the felsic, zircon-bearing, rocks as a circa $4 \mathrm{Ga}$ mafic rock with subchondritic Lu/Hf (Fig. 5a), 2) the Hadean event that fractionated Sm/Nd and Lu/Hf was done under lower mantle conditions where the fractionation of these two systems was not correlated (Caro et al., 2006; Hoffmann et al., 2011b; Rizo et al., 2011), 3) that zircon Hf systematics are not as robust as assumed, or 4 ) that the $\mathrm{U}-\mathrm{Pb}$ ages used to calculate initial $\varepsilon \mathrm{Hf}$ are incorrectly young.

A superchondritc $\mathrm{Sm} / \mathrm{Nd}$ ratio is a signature of an incompatible element depleted material. The boninitic composition rocks found in the Isua supracrustal unit (Polat et al., 2002) are the only samples that carry this compositional signal as they are significantly depleted in highly incompatible elements compared to the more typical tholeiitic basalt compositions (Fig. 7) (Hoffmann et al., 2010). The boninitic rocks have substantially superchondritic ${ }^{176} \mathrm{Lu} /{ }^{177} \mathrm{Hf}$ (up to 0.085 compared to chondritic 0.0336 ) and ${ }^{147} \mathrm{Sm} /{ }^{144} \mathrm{Nd}$ (up to 0.249 compared to chondritic 0.196) ratios (Frei et al., 2004; Hoffmann et al., 2010; O'Neil et al., 2016). These rocks also have extremely high initial $\varepsilon \mathrm{Hf}$ values of up to +13 and thus present $\mathrm{Hf}$ isotopic compositions in accord with, or more extreme, than the positive $\varepsilon^{143} \mathrm{Nd}$ and $\mu^{142} \mathrm{Nd}$ of the same rocks. Both the boninites and the more typical tholeiites from Isua have overlapping $\varepsilon^{143} \mathrm{Nd}$ and $\mu^{142} \mathrm{Nd}$ values suggesting that the source materials of both rock types experienced similar differentiation histories. The tholeiites, however, do not show the incompatible element depletion that would be expected to accompany the positive $\varepsilon^{143} \mathrm{Nd}$ and $\mu^{142} \mathrm{Nd}$ (Fig. 7). Hoffmann et al. (2011b) suggested that the apparent decoupling of $\mathrm{Hf}$ and $\mathrm{Nd}$ isotopic composition in the non-boninitic rocks from Greenland might reflect mixing between this high $\mathrm{Lu} / \mathrm{Hf}, \mathrm{Sm} / \mathrm{Nd}$ source and a less depleted component that had isotopic compositions similar to what the modern DM would have had at that time. They ascribe this mixing to overprinting of the highly depleted mantle component by fluids associated with subduction where a larger contribution to $\mathrm{Nd}$ than $\mathrm{Hf}$ is commonly observed (e.g. McCulloch and Gamble, 1991).

\section{FIGURE 7 HERE}

\subsection{2) Saglek-Hebron Complex}


The Saglek-Hebron Complex (SHC) in northern Labrador (Canada) (Fig. 1) is a terrane in the Nain Province mostly composed of Eoarchean TTG with enclaves of supracrustal rocks that can be up to a few $\mathrm{km}^{2}$ in size. It is part of the North Atlantic Craton and is often correlated to the early Archean rocks from SW Greenland (e.g. Nutman et al., 1996). Although the SHC has not been as extensively investigated as has SW Greenland, a number of recent studies are starting to provide important geochemical and isotopic evidence to unravel its crustal evolution. Rocks from the SHC, however, have been highly deformed and metamorphosed to upper amphibolite and granulite facies (Collerson and Bridgewater, 1979; Schiøtte et al., 1989), which can make the interpretation of isotopic signatures challenging compared to the SW Greenland rocks where at least limited areas have experienced less severe metamorphic conditions.

The oldest granitoids in the SHC have been dated at $3.9 \mathrm{Ga}$ (Collerson, 1983; Regelous and Collerson, 1996; Shimojo et al., 2016; Komiya et al., 2017; Vezinet et al., 2018; Wasilewski et al., 2018), but the province recorded multiple episodes of felsic magmatism from the Eoarchean to the Neoarchean (e.g. Schiøtte et al., 1989; Komiya et al., 2017; Salacinska et al., 2018; Wasilewski et al., 2018). The supracrustal rocks are mostly mafic amphibolites locally interbedded with detrital metasedimentary rocks and sometimes including chemical sediments (Bridgewater et al., 1975; Nutman et al., 1989; Bridgewater and Schiøtte, 1991). The mafic amphibolites are interpreted as basaltic metavolcanic rocks differentiated into more evolved liquids and incompatible-element-depleted pyroxene-rich cumulates (Wasilewski et al., 2019), with major and trace element compositions consistent with tholeiitic affinities (Fig. 7). As opposed to the Isua supracrustal belt, no metavolcanic rocks yet analyzed from the SHC share similar geochemical compositions with boninites (Wasilewski et al., 2019). The SHC mafic rocks have been divided into two supracrustal packages based on field observations. The older Nulliak unit appears to be crosscut by the Mesoarchean Saglek dikes, whereas the Upernavik unit is not, and thus is interpreted to be younger (Bridgewater et al., 1975; Baadsgaard et al., 1979). However, because the mafic metavolcanic rocks and the mafic Saglek dikes are now both hornblende-rich amphibolites, clear intrusive field relationships can be difficult to establish and the occurrence of distinct supracrustal packages is uncertain (Salacinska et al., 2018; Whitehouse et al., 2019). Mafic metavolcanic rocks from both units are also geochemically indistinguishable (Wasilewski et al., 2019).

The SHC also includes ultramafic rocks for which several origins have been proposed. Collerson et al. (1991) suggested the occurrence of two types of ultramafic rocks, including metakomatiites associated with the Nulliak supracrustal rocks, and slivers of lithospheric mantle found as enclaves in the TTG. They obtained Sm-Nd isochrons with ages of $4017 \pm 194$ Ma and $3815 \pm 121$ for the rocks they interpreted as metakomatiites and mantle slivers respectively. However, Re-Os analyses on equivalent suites of rocks yielded younger isochron ages of respectively $3612 \pm 130 \mathrm{Ma}$ and $3096 \pm 170 \mathrm{Ma}$ (Ishikawa et al., 2017). In contrast, Morino et al. (2017) suggested that all SHC ultramafic rocks are consistent with an origin as komatiite lavas. Mainly based on the $\mathrm{Al} / \mathrm{Ti}$ and $\mathrm{Gd} / \mathrm{Yb}$ ratios, they suggested the occurrence of Al-depleted, Al-undepleted and Al-enriched komatiites in the SHC. Wasilewski et al. (2019) studied an extensive suite of ultramafic rocks to conclude that the SHC includes two groups, mainly distinguished by their relative Fe contents, $\mathrm{Al} / \mathrm{Ti}$ ratios and contrasting trace element 
concentrations. The compositions of both suites of ultramafic rocks are controlled by fractionation of olivine of distinct forsterite contents, and both are consistent with ultramafic cumulates derived from komatiitic or picritic basalts, rather than truly komatiite lavas or lithospheric mantle. Fractionation of the low-Fe ultramafic cumulates from the primitive komatiitic basalt magma seems to have led to the formation of the mafic metavolcanic rocks whereas the high-Fe ultramafic rocks do not appear to be petrogenetically linked to the basaltic supracrustal rocks (Fig. 8). Their composition most closely resembles that of Al-depleted komatiites, albeit the relatively low estimated $\mathrm{MgO}$ content of their primary magma of 12 wt.\% suggests a basaltic rather than komatiitic parent magma (Wasilewski et al., 2019).

\section{FIGURE 8 HERE}

Recent Sm-Nd studies suggested the occurrence of two assemblages of mafic/ultramafic rocks in the SHC, derived from distinct mantle sources. A group of rocks yielded positive $\mu^{142} \mathrm{Nd}$, with an average value of +9 , while another group of samples shows no resolvable ${ }^{142} \mathrm{Nd}$ anomalies (Morino et al., 2017). The samples with high $\mu^{142} \mathrm{Nd}$ define a ${ }^{147} \mathrm{Sm}-{ }^{143} \mathrm{Nd}$ isochron with an age of $3782 \pm 93 \mathrm{Ma}$, while the samples with no ${ }^{142} \mathrm{Nd}$ anomalies fall on a younger isochron with an age of $3365 \pm 100 \mathrm{Ma}$. These two suites were therefore interpreted respectively as part of the Nulliak and Upernavik units (Morino et al., 2017). This study mostly examined ultramafic rocks, including samples that exhibit LREE enriched compositions that are unusual for ultramafic rocks. Wasilewski et al. (2019) interpreted the LREE enrichment of some ultramafic rocks to result from post-magmatic processes, which would impact the age obtained from the long-lived

${ }^{147} \mathrm{Sm}-{ }^{143} \mathrm{Nd}$ isochron. Both the Eoarchean and Mesoarchean isochrons also include ultramafic samples that have been interpreted to be derived from distinct primary magmas (Wasilewski et al., 2019) inconsistent with them being cogenetic. This interpretation also would affect the significance of the ages obtained from the isochron diagrams. The same two suites of samples yielded ${ }^{176} \mathrm{Lu}-{ }^{176} \mathrm{Hf}$ ages of $3794 \pm 130 \mathrm{Ma}$ and $3023 \pm 390 \mathrm{Ma}$ (Morino et al., 2017). The age discrepancy for the samples interpreted to be from the younger Upernavik unit may be indicative of disturbance of the long-lived isotopic systems. Regardless of the exact ages of the SHC ultramafic samples, the positive $\mu^{142} \mathrm{Nd}$ of some samples reflects pre-4 $\mathrm{Ga} \mathrm{Sm} / \mathrm{Nd}$ fractionation of their mantle source. Morino et al. (2017) suggested a mantle source formed at $4.4 \mathrm{Ga}$ with a ${ }^{147} \mathrm{Sm} /{ }^{144} \mathrm{Nd}$ ratio of 0.21 for the $\mathrm{SHC}$ rocks, which is similar to the source of the Greenland rocks (Fig. 5b,c).

Zircons from a $3.86 \mathrm{Ga}$ TTG sample from the SHC have been analyzed recently for their Hf isotopic composition. Most zircons yielded chondritic to slightly superchonditic initial $\varepsilon \mathrm{Hf}$ values, but were interpreted as being chondritic within uncertainty (Vezinet et al., 2018). Because all zircons are from the same rock sample, the $\varepsilon \mathrm{Hf}$ value of every zircon can be calculated at the same age, which best represents the crystallization age of the TTG magma, rather than at the ${ }^{207} \mathrm{~Pb} /{ }^{206} \mathrm{~Pb}$ ages determined for each zircon. The average $\varepsilon \mathrm{Hf}$ value for all zircons analyzed by Vezinet et al. (2018), calculated at $3.86 \mathrm{Ga}$, is +1.6 . This is also consistent with $\varepsilon \mathrm{Hf}$ values up to +3 for other SHC Eoarchean TTG (Wasilewski et al., 2018), suggesting a source with slightly superchondritic Lu/Hf. Despite the fact that the long-lived Lu-Hf system 
may have been disturbed to some extent at the whole-rock scale, the $\varepsilon \mathrm{Hf}$ value of +5.1 obtained from the ultramafic rock isochron (Morino et al., 2018) also supports the presence in the SHC of a reservoir with a superchondritic $\mathrm{Lu} / \mathrm{Hf}$. The value of $\varepsilon \mathrm{Hf}=+5$ at $\sim 3.8 \mathrm{Ga}$ is similar to the initial $\varepsilon \mathrm{Hf}$ of the Greenland boninitic rocks (Fig. 5a) (Hoffmann et al., 2010), although the chemical composition of the mantle-derived rocks from the SHC is not indicative of a mantle source as incompatible element depleted as for the Greenland boninitic rocks (Wasilewski et al., 2019). The SHC and SW Greenland Archean crustal sections thus appear to share a comparable early history and both denote the presence of a similar early incompatible element depleted mantle reservoir.

\section{2) The Nuvvuagittuq Greenstone Belt}

The northern part of the Superior Craton in Canada, the Minto Block, defines a good portion of the eastern border of Hudson Bay (Card, 1990). Most of this region consists of high-grade felsic gneisses. A fraction of this province, the Hudson Bay terrane, consists of a typical Archean TTG terrane. The felsic gneisses in the Hudson Bay terrane have ${ }^{147} \mathrm{Sm}-{ }^{143} \mathrm{Nd}$ model ages generally older than $3 \mathrm{Ga}$ (Boily et al., 2009) and are interpreted to be the cratonic nucleus of the Northeastern Superior Province. Within the Hudson Bay terrane are a series of greenstone belts, most of which are Neoarchean, but two, the Nuvvuagittuq and Ukaliq belts (Fig. 1), contain much older rocks. The best studied of these is the Nuvvuagittuq greenstone belt, a 6 $\mathrm{km}^{2}$ region of mostly mafic amphibolitic orthogneisses (Cates and Mojzsis, 2007; O'Neil et al., $2007,2011,2019)$. The mafic supracrustal rocks in this terrane, termed the Ujaraaluk unit (O'Neil et al., 2011), show considerable compositional overlap in both major and trace elements with the metabasalts from the ISB with the exception that the boninitic rocks from the Garbenschiefer unit range to more highly incompatible element depleted compositions (Fig. 7). The ISB volcanic sequence also contains more evolved rocks with intermediate compositions (Fig. 7) that have no analog in the Ujaraaluk. Many of the Ujaraaluk rocks are strongly affected by hydrothermal alteration, interpreted to occur during and shortly after eruption underwater (O'Neil et al., 2019), as also indicated by the occurrence of pillow basalts within the sequence. The Nuvvuagittuq greenstone belt is surrounded by Eoarchean felsic gneisses spanning a compositional range typical of Archean TTG terranes. The oldest felsic units present zircons with ages of $3.76 \mathrm{Ga}$, but several other nearby felsic rocks provide zircon ages ranging from 3.66 to $3.35 \mathrm{Ga}$ (O'Neil et al., 2013).

In spite of the compositional similarities between the Isua and Ujaraaluk rocks, the isotopic composition of these rocks reveals quite distinct geologic histories. The Ujaraaluk samples display a wider range in $\mu^{142} \mathrm{Nd}$ than do the Isua metabasalts and are dominated by negative $\mu^{142} \mathrm{Nd}$ instead of the positive values seen at Isua (Fig. 9) (O'Neil et al., 2016). In addition, the ${ }^{142} \mathrm{Nd} /{ }^{144} \mathrm{Nd}$ ratios of the Ujaraaluk rocks correlate with their $\mathrm{Sm} / \mathrm{Nd}$ ratios, with the slope of the correlation suggesting an age of $4.28 \mathrm{Ga}$ using a ${ }^{146} \mathrm{Sm}$ half-life of $103 \mathrm{Ma}$ (O'Neil et al., 2012). Not all groups working in this area interpret this correlation as an isochron. Roth et al. (2013, 2014) suggest that the correlation reflects a mixing line between $\sim 3.8$ Ga mantle-derived mafic volcanic rocks and some, not well defined, incompatible element enriched material of circa 4.5 Ga age. Whole-rock ${ }^{147} \mathrm{Sm}^{-143} \mathrm{Nd}$ and $\mathrm{Lu}-\mathrm{Hf}$ isochrons for the Ujaraaluk scatter widely with ages 
between 2.5 and 3.9 Ga (O'Neil et al., 2012, 2013; Guitreau et al., 2013; Roth et al., 2013), depending upon which group of rocks are included in the isochrons. The long-lived isotope systematics, however, are clearly disturbed by the growth of garnet in the rocks between 2.52.7 Ga (O'Neil et al., 2012, 2013), a period of metamorphism that also is marked by the growth of 2.6-2.7 Ga metamorphic zircons in the Ujaraaluk (Darling et al., 2013). The clear metamorphism-induced compositional changes recorded in the rocks render the age information provided by the long-lived radioactive chronometers in the Ujaraaluk unreliable. The same conclusion must be reached in the case of the mixing model since in this model the rocks would have had a range in isotopic composition at the time of their eruption. In contrast, the Ujaraaluk samples that do not contain garnet show more consistent initial isotope systematics, but also a much smaller range in $\mathrm{Sm} / \mathrm{Nd}$ and $\mathrm{Lu} / \mathrm{Hf}$ ratios and hence fail to define precise isochrons. Large differentiated gabbro sills intruding the Ujaraaluk yield relatively a well-defined ${ }^{147} \mathrm{Sm}-{ }^{143} \mathrm{Nd}$ isochron with an age of $4.12 \mathrm{Ga}$, which would establish this as the minimum age of the Ujaraaluk (O'Neil et al., 2012). In our opinion, attempts to explain the Hadean ${ }^{146} \mathrm{Sm}-{ }^{142} \mathrm{Nd}$ age as a mixing artifact do not adequately address several aspects of the available data, but these arguments have been made in detail previously (O'Neil et al., 2012, 2019).

\section{FIGURE 9 HERE}

Regardless of the true eruption/emplacement age of the Ujaraaluk rocks, the range they display in $\mu^{142} \mathrm{Nd}$ clearly tracks Hadean chemical differentiation events. In the Eoarchean rocks of Greenland and Labrador, the initial $\mu^{142} \mathrm{Nd}, \varepsilon^{143} \mathrm{Nd}$ and $\varepsilon \mathrm{Hf}$ extend from values within the range that the modern mantle would have had in the Eoarchean to values indicative of a highly incompatible-element-depleted source formed in the early Hadean. For the Ujaraaluk rocks, however, the depleted end member is the one with $\mu^{142} \mathrm{Nd}$ similar to that of the modern DM mantle, whereas the data predominantly extend to compositions expected for Hadean incompatible element enriched materials. If the Ujaraaluk rocks indeed are $4.28 \mathrm{Ga}$, the nature of the enriched component is clear, it is simply the more incompatible element enriched end members of the compositional range of the Ujaraaluk rocks. The compositional range of the Ujaraaluk rocks (i.e. their range in $\mathrm{Sm} / \mathrm{Nd}$ ) would then explain the range of ${ }^{142} \mathrm{Nd} /{ }^{144} \mathrm{Nd}$ measured for them today. If the Ujaraaluk rocks are instead $\sim 3.8 \mathrm{Ga}$, then the enriched component is a hypothesized Hadean incompatible element enriched material (Roth et al., 2013,2014 ) that conceivably could be the chemical compliment to the depleted source sampled in SW Greenland and Labrador, but such an enriched source is never expressed in the Eoarchean rocks from the North Atlantic Craton (Fig. 9).

The compositional features of the Ujaraaluk mafic rocks are appropriate to serve as the source rocks, if melted, for the felsic rocks that surround the Nuvvuagittuq greenstone belt (Adam et al., 2012), and their characteristically negative $\mu^{142} \mathrm{Nd}$ provides a perfect tracer to evaluate their role as sources for the younger felsic rocks. The Eoarchean felsic rocks around the Nuvvuagittuq belt indeed do show negative $\mu^{142} \mathrm{Nd}$ (O'Neil et al., 2012; Roth et al., 2013), and the negative values extend to felsic rocks as young as $2.7 \mathrm{Ga}$ (O'Neil and Carlson, 2017). The evidence for a Hadean incompatible element enriched source for the Hudson Bay felsic rocks is supported by 
the $\mathrm{Hf}$ isotopic composition of their zircons (Guitreau et al., 2013; O'Neil et al., 2013). The zircon initial $\varepsilon \mathrm{Hf}$ show a continual decrease in values becoming more negative with time in the TTGs (Fig. 10a). The magnitude of decrease in $\mathrm{\varepsilon Hf}$ is consistent with source rocks evolving with ${ }^{176} \mathrm{Lu} /{ }^{177} \mathrm{Hf}$ between 0.020 and 0.029 , within the range measured for the Ujaraaluk mafic samples (Fig. 10b). An exception is seen in the oldest TTGs near Nuvvuagittuq that extend the $\varepsilon \mathrm{Hf}$ values upwards to just below the value of the DM at $3.8 \mathrm{Ga}$. The samples with positive initial $\varepsilon \mathrm{Hf}$, however, have negative $\mu^{142} \mathrm{Nd}$ indicative of a source for their $\mathrm{Nd}$ in a Hadean LREE enriched material. Both the $\mu^{142} \mathrm{Nd}$ and zircon initial $\varepsilon \mathrm{Hf}$ data for the Nuvvuagittuq TTG's thus appear to reflect continual reprocessing of Hadean mafic basement, similar to that of the Ujaraaluk supracrustal rocks, for about $1.5 \mathrm{Ga}$. The data for the Hudson Bay terrane thus paint a rather simple picture for the petrogenesis of this crustal section. This crustal block began with the construction of a mafic platform produced by dry melting of mantle (O'Neil et al., 2011) with isotopic characteristics within the range the modern DM mantle would have had circa 4.3 Ga. The stratigraphically correlated compositional change seen in the Ujaraaluk suggests the development of a subduction system against the mafic plateau that transferred water into the mantle to instigate melting of mantle that was additionally depleted in incompatible elements only shortly before the melting event (O'Neil et al., 2012). If this sequence of events occurred at $4.28 \mathrm{Ga}$, then there was a $600 \mathrm{Ma}$ period of quiescence before remelting of this composite mafic platform produced the oldest of the TTG in the Hudson Bay terrane. Repeated melting of this mafic basement then was responsible for building the terrane over the next billion years, with little or no apparent input needed from newly mantle derived contributions to the crust building (O'Neil and Carlson, 2017).

\section{FIGURE 10 HERE}

\section{3) The Slave Craton}

The Slave craton (Figs. 1, 11) contains the oldest terrestrial rocks dated using zircon U-Pb at 4.02-4.03 Ga (Bowring and Williams, 1999; Reimink et al., 2016b). The clear evidence for Hadean crust in the Slave is accompanied by a wide range in initial $\mathrm{Nd}$ and $\mathrm{Hf}$ isotopic compositions that have driven much discussion about the degree to which the rocks of the Slave craton involve contributions from Hadean components (Bowring et al., 1990; Davis and Hegner, 1992; Davis et al., 1996; lizuka et al., 2006; lizuka et al., 2009).

\section{FIGURE 11 HERE}

The broader Slave craton is comprised of the typical granite-greenstone associations that constitute the basement rocks of most cratons. The Slave, however, is distinguished by a remarkably long record of magmatism occurring in approximately 150-200 Ma intervals extending from 4.02 to $2.8 \mathrm{Ga}$ (Bleeker et al., 1999; Sircombe et al., 2001; Ketchum et al., 2004). After a short magmatic hiatus during which a sedimentary cover group was deposited (Isachen and Bowring, 1994), igneous activity resumed in the Slave with the eruption between 2.72 to $2.65 \mathrm{Ga}$ of the mafic to felsic volcanic rocks of the Yellowknife Supergroup (Isachen et al., 1991), followed by intrusion of large volumes of 2.58-2.62 Ga tonalites to granites (Van Breemen et al., 
1992) that constitute the last major igneous events on the craton in the Archean. The initial $\mathrm{Nd}$ and $\mathrm{Pb}$ isotopic composition of these Neoarchean granitoids and associated sulfide deposits have been used to divide the craton into a younger eastern section and the older western section (Bleeker et al., 1999). The intrusions in the eastern portion have positive initial $\varepsilon^{143} \mathrm{Nd}$ values and $\mathrm{Pb}$ isotopic compositions suggestive of sources not long removed from the mantle prior to genesis of the granitoids (Davis and Hegner, 1992; Thorpe et al., 1992; Davis et al., 1996). Neoarchean intrusions to the west routinely have negative initial $\varepsilon^{143} \mathrm{Nd}$ suggestive of the involvement of older, LREE enriched, crustal rocks in the genesis of the Neoarchean rocks. The isotopic boundary (Fig. 11) is broadly consistent with the lack of exposure of pre-2.8 Ga rocks in the eastern craton, but large areas of 2.8 to $3.5 \mathrm{Ga}$ gneisses in the western portion of the craton termed the Central Slave Basement complex (Bleeker et al., 1999).

The western-most portion of the craton (Fig. 11), the Acasta Gneiss Complex, contains the oldest components in the craton. Besides the 4.02-4.03 Ga rocks in Acasta, evidence for even older components is shown clearly by one $4.2 \mathrm{Ga}$ xenocrystic zircon core in a younger, 3.9 Ga, gneiss (lizuka et al., 2006) and suggested by highly variable initial $\varepsilon^{143} \mathrm{Nd}$ in the basement gneisses (Bowring and Housh, 1996). As in most studies of polymetamorphic Archean terranes, the interpretation of the variable initial $\mathrm{Nd}$ isotopic composition of the rocks has seen the typical debate about whether the data reflect primary source heterogeneity or are instead caused by post-magmatic changes to the whole rock $\mathrm{Sm} / \mathrm{Nd}$ used to calculate the initial ${ }^{143} \mathrm{Nd} /{ }^{144} \mathrm{Nd}$ ratios, likely induced by periods of high-grade metamorphism (Bowring and Housh, 1996; Moorbath and Whitehouse, 1996). This is where more recent information on zircon initial $\mathrm{Hf}$ and ${ }^{142} \mathrm{Nd}$ isotopic data is helpful. Initial $\varepsilon \mathrm{Hf}$ values for zircons from the $4.02 \mathrm{Ga}$ Idiwhaa gneiss, the oldest unit in the Slave, are -2 (Reimink et al., 2016b), which is similar to the $\varepsilon \mathrm{Hf}$ values found in slightly younger (3.96-3.92 Ga) tonalitic rocks (Amelin et al., 1999; lizuka et al., 2007, 2009; Guitreau et al., 2014; Bauer et al., 2017; Reimink et al., 2019). This could suggest either an initial crust forming event that tapped mantle with slightly sub-chondritic $\mathrm{Hf}$ isotope evolution at that time, or a (crustal?) source with subchondritic Lu/Hf generated by melting a DM-like source earlier in the Hadean. If the Idiwhaa unit was derived from, or interacted with, a subchondritic Lu/Hf reservoir, that reservoir was likely mafic crust as opposed to typical Archean felsic crust (Reimink et al., 2016b). The negative $\varepsilon \mathrm{Hf}$ is supported by both negative $\mu^{142} \mathrm{Nd}$ in the old Acasta rocks (Roth et al., 2014; Reimink et al., 2018) and the fact that the $\varepsilon \mathrm{Hf}$ of the Acasta rocks $>3.6 \mathrm{Ga}$ (Fig. 12) define a steep trend in $\varepsilon \mathrm{Hf}$ versus time that extends well into the negative $\varepsilon \mathrm{Hf}$ field by $3.6 \mathrm{Ga}$ (Amelin et al., 1999; lizuka et al., 2009; Guitreau et al., 2013; Bauer et al., 2017; Reimink et al., 2019). The pre-3.6 Ga Acasta data thus suggest that this first phase of crust building in the Slave started about $4.2 \mathrm{Ga}$ (the age of the oldest xenocrystic zircon core and the extrapolation of the $\mathrm{Hf}$ isotope evolution to $\varepsilon \mathrm{Hf}=0$ ). A protolith age of order 4.2-4.3 Ga would explain both the $\varepsilon \mathrm{Hf}$ and $\mu^{142} \mathrm{Nd}$ data for the Acasta rocks older than 3.6 $\mathrm{Ga}$ assuming that the protolith has $\mathrm{Lu} / \mathrm{Hf}$ and $\mathrm{Sm} / \mathrm{Nd}$ within the range typical of mafic rocks.

FIGURE 12 HERE 
When considering the $\mu^{142} \mathrm{Nd}$ and $\varepsilon \mathrm{Hf}$ values of individual rocks, as in figure 13 , the Acasta data suggest a compositionally distinct source from that of the 3.8 and 3.6 Ga felsic rocks in Nuvvuagittuq, mainly distinguished by the differences in $\varepsilon \mathrm{Hf}$ at similar times. Figure 13 shows the model $\mathrm{Lu} / \mathrm{Hf}$ and $\mathrm{Sm} / \mathrm{Nd}$ data for two Eoarchean felsic rocks from the Acasta Gneiss Complex, a 3.94 tonalite $\left(\mu^{142} \mathrm{Nd}=-6, \varepsilon \mathrm{Hf}=-4.5\right)$ and $3.75 \mathrm{G}$ a tonalite $\left(\mu^{142} \mathrm{Nd}=-9, \varepsilon \mathrm{Hf}=-8\right)$. The source for these tonalites likely had a lower $\mathrm{Lu} / \mathrm{Hf}$ ratio than those of the Nuvvuagittuq tonalites, evidenced by their lower $\varepsilon \mathrm{Hf}$ values, though they have similar $\mu^{142} \mathrm{Nd}$ values, resulting in curves that plot lower on this figure. One explanation is that the source in Acasta was perhaps slightly more felsic than the source to the Nuvvuagittuq tonalites, as more felsic rocks typically have lower Lu/Hf than mafic rocks (Fig. 13). We note, however, that a recent compilation of whole rock composition for crustal rocks shows lower $\mathrm{Lu} / \mathrm{Hf}$ at a given $\mathrm{SiO}_{2}$ than commonly used averages for felsic and mafic rocks (Bea et al., 2018) so a truly felsic Hadean crust in the Acasta source may not be necessary. Hadean felsic crust was clearly present in Acasta, however, evidenced by the 4.2 Ga xenocrystic zircon core (lizuka et al., 2007).

\section{FIGURE 13 HERE}

For Acasta area rocks 3.6 Ga and younger, the zircon initial $\mathrm{Hf}$ isotope data show a wide range in values (Fig. 12) extending from negative $\mathrm{\varepsilon Hf}$ values near the evolution trend of hypothetical Hadean mafic crust, upwards to values near zero. Continuing on to younger age from the Acasta rocks, samples from the Central Slave Basement Complex, a swath of cratonic basement gneisses exposed $\sim 100 \mathrm{~km}$ to the east of Acasta (Fig. 11), extend the $\mathrm{kHf}$ variability into the positive range approaching values estimated for depleted mantle by $3.4 \mathrm{Ga}$. The $\mu^{142} \mathrm{Nd}$ data also show a return to values near zero in Slave craton rocks younger than 3.6 Ga (Reimink et al., 2018). The observation that the younger rocks in the Acasta region show a wide range of initial $\varepsilon \mathrm{Hf}$ suggests that the younger juvenile magmas intruded pre-existing Hadean crust in the Acasta region and were contaminated by it. The presence of $\varepsilon \mathrm{Hf}$ values near 0 also shows a dramatic shift in source age, composition, or both, as primary inputs to the $\sim 3.6 \mathrm{Ga}$ Acasta magmatic system must have been near chondritic or potentially slightly elevated above chondritic.

In contrast, east of Acasta, in the region where the Central Slave Basement Complex is exposed, there is no sign of involvement of this Hadean crust as either source or contaminant of the Meso-Neoarchean magmas that formed the Central Slave Basement Complex. The data thus indicate that this large portion of the craton was created during the Mesoarchean from mantlederived magmas (Reimink et al., 2019). This result is quite different from that discussed previously for Nuvvuagittuq where the data indicate reworking of Hadean crust to make younger crustal rocks throughout most of the Archean. In the Slave, the building of the initial crustal block also appears to have been dominated by reworking of a Hadean mafic crust, but the transition at $3.6 \mathrm{Ga}$ to "mantle" sources in Acasta and then continuing on in the Central Slave Basement Complex suggests a transition in the mechanism of crust creation in the Slave at that time. A similar transition to more juvenile composition sources is also observed in southwestern Greenland, but occurs later at 3.2 Ga (Naeraa et al., 2012). Reimink et al. 
(2016a) documented a gradual change in the REE patterns of the Acasta gneisses with the oldest rocks having relatively flat patterns and negative Eu anomalies, but the $3.6 \mathrm{Ga}$ rocks are quite depleted in HREE with either no, or positive, Eu anomalies (Fig. 14).

\section{FIGURE 14 HERE}

The changing patterns indicate a transition from relatively shallow melting or fractionation to generate the oldest (4.02-3.75 Ga) magmas, whereas the younger magmas (<3.6 Ga) were generated at sufficient depths to stabilize garnet in the melting residue. For the Acasta region where the data clearly show the long-term involvement of Hadean basement in the generation or contamination of new crustal additions to the area, one could imagine the changing depth of melting reflecting the creation of a thickening crustal block through time with the depth of remelting increasing with time. A new source input, however, is required by the presence of rocks with $\mathrm{\varepsilon Hf}=0$ at $3.6 \mathrm{Ga}$, so the mechanism was not simply increased crustal thickening of a single plateau-like mafic crustal package. New additions to the crustal package from the mantle are required. Likewise, for the Central Slave Basement, where there is no evidence for the involvement of significantly older crust, the wide range of La/Yb of these samples (Reimink et al., 2019) suggests that another petrogenetic mechanism drove the range of apparent melting depths. An obvious candidate is the involvement of subduction where various melting and fractionation processes can work, at least in modern subduction systems, to produce a variety of trace-element signatures yet consistent isotopic patterns that track the presence of older crustal basement rocks (e.g. the Western U.S. Cordillera; Kistler and Peterman (1973); Chapman et al. (2017)). The fact that all of these different magma types have similar initial $\varepsilon \mathrm{Hf}$ indicates that all components involved in the production of the Central Slave igneous basement had isotopic compositions within the range the modern depleted mantle would have had in the Archean.

\section{4) Jack Hills}

Although the oldest rocks dated with zircons are in the Acasta region, the oldest terrestrial minerals are detrital zircons found in ca. 3 Ga quartzites and conglomerates from the Jack Hills, Western Australia (Fig. 1) (Froude et al., 1983; Harrison, 2009; Cavosie et al., 2019). Several studies have examined the initial $\mathrm{Hf}$ isotopic composition of the Jack Hills zircons (Amelin et al., 1999; Harrison et al., 2005; Blichert-Toft and Albarède, 2008; Harrison et al., 2008; Kemp et al., 2010). Two studies examined the Sm-Nd systematics of zircons from Jack Hills. One (Amelin, 2004) examined individual zircons, but the small quantities of $\mathrm{Nd}$ recovered limited the isotopic precision and hindered clear interpretation of the initial $\mathrm{Nd}$ isotope data. Another attempt (Caro et al., 2008) involved analysis of a large composite of 790 grains of varying age, but showed the Sm-Nd systematics in these zircons to have been highly disturbed. Similar evidence for disturbance, specifically late addition of a light-REE enriched component, also was observed in the Amelin (2004) study. The zircon Hf data for the Jack Hills sediments, and for related igneous rocks from the Narryer Terrane of the Yilgarn Craton forms a huge scatter in $\varepsilon \mathrm{Hf}$ versus time (Fig. 15), but refinement of the techniques enabling age information to be evaluated from the same spot as is analyzed for Lu-Hf systematics, and examining just the data for those 
zircons that show igneous oscillatory zoning and lack of evidence for disturbed $\mathrm{U}-\mathrm{Pb}$ systematics produces a good correlation of initial $\varepsilon \mathrm{Hf}$ with time (Harrison et al., 2008; Kemp et al., 2010; Bell et al., 2011, 2014). The $\varepsilon \mathrm{Hf}$ in these zircons decrease along an evolution line with ${ }^{176} \mathrm{Lu} /{ }^{177} \mathrm{Hf}=0.02$ that is closer to a typical $\mathrm{Lu} / \mathrm{Hf}$ ratio of mafic rocks than an evolved composition like a trondhjemite (Fig. 15).

An unfortunate aspect of these Hadean zircons is that the rocks from which they derive no longer exist. Attempts made to reconstruct the nature of their source rocks using $\mathrm{Ti}$ crystallization temperatures of the zircons (Harrison et al., 2008), their oxygen isotopic compositions (Mojzsis et al., 2001; Valley et al., 2002; Cavosie et al., 2005; Harrison et al., 2008), and mineral inclusions (Hopkins et al., 2008), reach the conclusion that the source rocks were low melting temperature, hydrous, granitoid rocks. This conclusion, however, is contentious (Nebel et al., 2014). As with all the cratons considered previously, however, the Hfisotope evolution of the Jack Hills zircons indicates a protolith(s) with Lu/Hf ratios more typical of mafic rocks than of evolved felsic rocks such as trondhjemites, though some felsic rocks do have $\mathrm{Lu} / \mathrm{Hf}$ ratios this high. The $\mathrm{Hf}$ isotopic evolution of the Jack Hills zircons thus is similar to that seen in the $>3.6$ Ga gneisses at Acasta and the Neo-to-Eoarchean TTG of Nuvvuagittuq, with all three suggesting that the rocks in which these zircons formed were derived by the remelting of Hadean mafic basement.

\section{FIGURE 15 HERE}

\section{5) The Kaapvaal Craton}

The Kaapvaal Craton (Fig. 1) provides an interesting contrast to all the Archean crustal blocks discussed so far in that its oldest rocks are the youngest so far considered, and its mafic/ultramafic (komatiite) component figures more prominently in various petrogenetic models for building this Paleoarchean craton. The oldest rocks in the Kaapvaal Craton are along its northeastern margin. As with most Archean terranes, initial $\varepsilon \mathrm{Hf}$ and $\varepsilon^{143} \mathrm{Nd}$ for the Paleoarchean basement igneous rocks scatters considerably (Fig. 16a,b). In the northeastern Kaapvaal, both TTG and mafic/ultramafic rocks show substantial overlap in initial $\varepsilon \mathrm{Hf}$ and $\varepsilon^{143} \mathrm{Nd}$. An important observation for the Kaapvaal Paleoarchean data is that, like the case for the Eoarchean rocks from Greenland, the zircon data for the oldest rocks have an average $\varepsilon \mathrm{Hf}=$ $0 \pm 3(2 \sigma, n=84)$, yet the whole rock initial $\varepsilon \mathrm{Hf}$ for both the TTG (average $\varepsilon \mathrm{Hf}=+1.5 \pm 3.3$ $2 \sigma, n=35$ ) and the mafic/ultramafic rocks (average $\varepsilon \mathrm{Hf}=+4 \pm 92 \sigma, \mathrm{n}=63$ ) in the craton are predominantly positive extending up to values in the range expected for the DM at the formation age of these rocks (Fig. 16a). For an assumed DM with $\varepsilon \mathrm{Hf}$ of +4 at $3.6 \mathrm{Ga}$, a mafic protolith with a ${ }^{176} \mathrm{Lu} /{ }^{177} \mathrm{Hf}$ ratio of 0.02 would require about $440 \mathrm{Ma}$ to evolve to $\mathrm{\varepsilon Hf}=0$, pushing the age of the possible protolith for the Paleoarchean Kaapvaal felsic rocks back into the range of the oldest detrital zircon found in Kaapvaal sediments (Byerly et al., 2018).

FIGURE 16 HERE 
The northeastern Kaapvaal mafic/ultramafic rocks also range widely $(-7$ to +6$)$ in initial $\varepsilon^{143} \mathrm{Nd}$ values (Fig 16b). The cause of this large range in initial $\varepsilon^{143} \mathrm{Nd}$ is not entirely clear, though the amount of scatter in both $\mathrm{Lu}-\mathrm{Hf}$ and $\mathrm{Sm}-\mathrm{Nd}$ isochrons for the Komatii Formation komatiites have been interpreted to reflect either post eruption metamorphic modification of the $\mathrm{Sm} / \mathrm{Nd}$ ratios or possible incorporation of a recycled sedimentary component in the source of these komatiites (Blichert-Toft et al., 2015). In contrast to the wide range in initial Nd isotopic composition of the komatiites, and unlike the positive $\varepsilon^{143} \mathrm{Nd}$ that characterize the majority of Eoarchean felsic rocks from Greenland, the data for Kaapvaal TTG whole rocks average to $\varepsilon^{143} \mathrm{Nd}=0 \pm 3(2 \sigma, \mathrm{n}=110)$ from 3.2 to $3.6 \mathrm{Ga}$ (Fig. 16b). Given that the TTG overlap in initial $\mathrm{Nd}$ and $\mathrm{Hf}$ isotopic composition with the mantle-derived komatites from the same area and similar age, one interpretation of the data is that all the Kaapvaal Paleoarchean rocks were derived from a mantle source that had $\varepsilon \mathrm{Hf}$ and $\varepsilon^{143} \mathrm{Nd}$ near zero and that the time interval between production of a mafic crust and its remelting to produce the TTG suite was short enough that no detectable isotope difference could evolve to distinguish the TTG from the komatiites. Given the wide range in initial $\mathrm{Nd}$ and $\mathrm{Hf}$ isotopic composition of the komatiites, however, an equally valid interpretation is that the TTG components of the northeastern Kaapvaal were derived by remelting of a preexisting crustal platform. If that basement platform was mafic in composition, e.g. had ${ }^{176} \mathrm{Lu} /{ }^{177} \mathrm{Hf}$ near 0.02 and ${ }^{147} \mathrm{Sm} /{ }^{144} \mathrm{Nd}$ near 0.18 , then the basement was of order $4.1 \mathrm{Ga}$ (Fig. 16a,b), similar in age to the oldest zircon in Kaapvaal sediments. In this scenario, the range in $\varepsilon^{143} \mathrm{Nd}$ at any time could be explained as mixing between the $4.1 \mathrm{Ga}$ crustal protolith and newly derived magmas from the DM, with the protolith ${ }^{143} \mathrm{Nd}$ evolution defining the lower limit of the $\varepsilon^{143} \mathrm{Nd}$ variation seen in the Kaapvaal felsic rocks. This would imply that the Paleoarchean activity involved both reworking of Hadean components as well as a large component of new crustal additions from the mantle, represented most clearly by the mafic/ultramafic volcanic rocks. Another option, however, is to assume that the TTG component of the Kaapvaal was derived by remelting a much more evolved basement. For example, for protolith ${ }^{176} \mathrm{Lu} /{ }^{177} \mathrm{Hf}=0.01$ and ${ }^{147} \mathrm{Sm} /{ }^{144} \mathrm{Nd}=0.13$, a protolith model age of circa $3.6 \mathrm{Ga}$ can produce evolution lines that pass through at least a subset of the Kaapvaal data with time (Fig. 16a,b).

\section{FIGURE 17 HERE}

In the case of the Kaapvaal, the ${ }^{146} \mathrm{Sm}-{ }^{142} \mathrm{Nd}$ system is of limited use because even for a protolith age of $4.1 \mathrm{Ga}$, the abundance of ${ }^{146} \mathrm{Sm}$ is so low that it can only make detectable changes in $\mu^{142} \mathrm{Nd}$ in rocks with extreme $\mathrm{Sm} / \mathrm{Nd}$ ratios. For example, a $4.1 \mathrm{Ga}$ protolith with ${ }^{147} \mathrm{Sm} /{ }^{144} \mathrm{Nd}=0.18$ would have a $\mu^{142} \mathrm{Nd}$ of -1 by $3.6 \mathrm{Ga}$, which overlaps many of the values seen in the Kaapvaal felsic rocks, and is indistinguishable from zero given typical measurement precisions of $\pm 3-5 \mu$. The available ${ }^{142} \mathrm{Nd}$ data for the oldest rocks of the Kaapvaal craton show a relatively small range in $\mu^{142} \mathrm{Nd}$ (Fig. 17) (-8 to +5.4 , averaging $-2 \pm 7(2 \sigma, n=36)$ ) (Caro et al., 2006; Puchtel et al., 2013, 2016; Schneider et al., 2018) compared to the other cratons discussed previously. There is no significant difference in average $\mu^{142} \mathrm{Nd}$ between the mafic rocks and the TTG of the Kaapvaal craton. The marginally negative average $\mu^{142} \mathrm{Nd}$ of the Kaapvaal rocks is consistent with the oldest preserved rocks being generated from, or 
interacting with, preexisting LREE enriched crust, but the small range of values that overlaps with $\mu^{142} \mathrm{Nd}=0$ does not provide compelling evidence for this explanation.

\section{5) Hafnium-Tungsten}

Up to this point, we have not discussed the evidence for early differentiation events recorded by the decay of ${ }^{182} \mathrm{Hf}$ to ${ }^{182} \mathrm{~W}$. This is intentional, as the data available for ${ }^{182} \mathrm{~W} /{ }^{184} \mathrm{~W}$ in ancient rocks does not obviously correlate with the $\mathrm{Nd}$ and $\mathrm{Hf}$ systematics in the same terranes. Figure 18 shows the $\mu^{182} \mathrm{~W}$ data for the ancient crustal rocks analyzed for $\mathrm{W}$, along with data for a wider age range of crustal samples represented by glacial diamictites (Mundl et al., 2018) and, the range of $\mathrm{W}$ isotopic compositions in modern ocean island basalts (OIB). The majority of Archean/Hadean rocks have $\mu^{182} \mathrm{~W}$ within the range of $10 \pm 5$, just a bit lower than the 20 seen in lunar samples (Touboul et al., 2015; Kruijer and Kleine, 2017). The range is independent of rock type and age from over $4 \mathrm{Ga}$ in Acasta (Willbold et al., 2015; Reimink et al., 2018) and Nuvvuagittuq (Touboul et al., 2014) to the 2.7 Ga Boston Creek (Puchtel et al., 2018) and 2.8 Ga Kostomuksha (Touboul et al., 2012) komatiites.

\section{FIGURE 18 HERE}

The most distinctive $\mu^{182} \mathrm{~W}$ signatures in Archean/Hadean rocks are seen in two komatiite provinces, both from the Barberton Mountain Lands of South Africa. The Komati komatiites have $\mu^{182} \mathrm{~W}$ just slightly above zero (Touboul et al., 2012), while the Schapenburg komatiites are unique so far in showing substantially negative $\mu^{182} \mathrm{~W}$ (Puchtel et al., 2016), in the range seen for modern intraplate volcanism. All the Archean diamictites analyzed by Mundl et al. (2018) are from South Africa, and all have negative $\mu^{182} \mathrm{~W}$, indicating that this rather unique signature for the Archean is present in a range of rock types exposed in the upper crust of South Africa.

Because the daughter elements in both the Hf-W and $\mathrm{Sm}-\mathrm{Nd}$ systems are more incompatible than the parent elements during silicate differentiation processes, ${ }^{142} \mathrm{Nd}$ and ${ }^{182} \mathrm{~W}$ isotope variations should correlate positively if fractionation occurred while both parents were extant. Given the very short half-life of ${ }^{182} \mathrm{Hf}$, a fractionation event that occurred early enough to result in distinct ${ }^{182} \mathrm{~W} /{ }^{184} \mathrm{~W}$ should create a large imprint on ${ }^{142} \mathrm{Nd} /{ }^{144} \mathrm{Nd}$, but the total range in ${ }^{142} \mathrm{Nd} /{ }^{144} \mathrm{Nd}$ is only slightly larger than that observed in ${ }^{182} \mathrm{~W} /{ }^{184} \mathrm{~W}$ for ancient rocks. The small range in ${ }^{142} \mathrm{Nd} /{ }^{144} \mathrm{Nd}$ and its lack of correlation with ${ }^{182} \mathrm{~W} /{ }^{184} \mathrm{~W}$ in ancient rocks suggests that the $\mathrm{W}$ isotope variability is not caused by an initial differentiation of the silicate Earth, as would be expected to result from crystallization of a terrestrial magma ocean. Rizo et al. (2016) modeled the evolution of a terrestrial magma ocean and showed that $\mu^{182} \mathrm{~W}$ and $\mu^{142} \mathrm{Nd}$ values of +15 to +20 , as seen in rocks from Greenland, could be produced in the residue of $30 \%$ melt extraction that occurred in the mantle about $60 \mathrm{Ma}$ after the beginning of Solar System formation. While this type of model could explain the positive $\mu^{182} \mathrm{~W}$ and $\mu^{142} \mathrm{Nd}$ characteristic of the Eoarchean rocks from Greenland, it cannot explain the positive $\mu^{182} \mathrm{~W}$ coupled with negative $\mu^{142} \mathrm{Nd}$ seen in Nuvvuagittuq and Acasta. The suggestion has been made that the consistency of $\mu^{182} \mathrm{~W}$ across so many different rock types within a terrane reflects the high 
mobility of W in crustal fluids (Liu et al., 2016). That so many of the ancient terranes, of different age and rock type, show overlapping $W$ isotopic compositions provides a strong argument that the positive $\mu^{182} \mathrm{~W}$ likely was the signature of the portion of the mantle that gave rise to the rocks in these terranes.

In trying to explain the range in $\mu^{182} \mathrm{~W}$ and $\mu^{142} \mathrm{Nd}$ in early Earth rocks, both chondritic meteorites and Earth's core have very different $\mu^{182} \mathrm{~W}$ compared to the mantle. Both chondritic and core $\mu^{182} \mathrm{~W}$ are about -200 or lower (e.g. Kleine et al., 2009) compared to mantle $\mu^{182} \mathrm{~W}=0 \pm 20$. In contrast, chondrites have $\mu^{142} \mathrm{Nd}$ only from about -30 to 0 (Boyet and Carlson, 2005; Carlson et al., 2007; Gannoun et al., 2011; Bouvier and Boyet, 2016; Burkhardt et al., 2016; Fukai and Yokoyama, 2017) and neither the core nor chondritic meteorites have high enough $\mathrm{Nd}$ concentration compared to mantle concentrations to affect the $\mathrm{Nd}$ isotopic composition of the silicate Earth. The consequence is that $\mathrm{W}$ isotopic compositions in Earth are very sensitive to mixing of the mantle with either chondrites or core, whereas neither of these processes will have a substantial effect on $\mu^{142} \mathrm{Nd}$. Early work on the $\mathrm{W}$ isotopic composition of ancient mantle-derived rocks focused on explaining the positive $\mu^{182} \mathrm{~W}$ compared to the modern mantle with the assumption that the mantle in the Archean had not yet received its full complement of late-accreted chondritic material that is now present in the modern mantle (Willbold et al., 2011; Touboul et al., 2014; Rizo et al., 2016). Late accretion, where "late" means after core-mantle chemical exchange became insignificant, is a time-honored explanation (e.g. Chou et al., 1983; Walker, 2009) for the unexpectedly high, and chondritic relative, abundances of the highly siderophile elements ( $\mathrm{Au}, \mathrm{Os}, \mathrm{Ir}, \mathrm{Ru}, \mathrm{Pt}, \mathrm{Pd}, \mathrm{Re}$ ) in the mantle. Because $\mathrm{W}$ is a moderately siderophile element, and its isotopic composition in chondrites is dramatically different than in Earth's mantle, the addition of as little as $0.2-0.8 \%$ of the mass of Earth's mantle of chondritic material would lower the $\mu^{182} \mathrm{~W}$ of the mantle by about $15 \mathrm{ppm}$ (Willbold et al., 2011). This amount is also within the range needed to explain the highly siderophile element (HSE) abundances of the mantle. Support for this idea was provided by the suggestion that komatiites through the Archean document a gradual increase in HSE abundances in the mantle (Maier et al., 2009), but the evidence for this conclusion has been questioned on the basis of more recent komatiite analyses that do not show a clear trend in mantle HSE abundances through time (Puchtel et al., 2014; Waterton et al., 2017). In addition, the HSE data for Archean rocks show that estimated mantle source HSE abundances decrease with decreasing $\mu^{182} \mathrm{~W}$, the opposite of what would be expected for mixing in a high HSE, low $\mu^{182} \mathrm{~W}$ component, like chondrite or core, into the mantle. For example, HSE studies of the Schapenburg (Puchtel et al., 2016) and Komati (Puchtel et al., 2014) komatiites and ultramafic rocks from Isua (Rizo et al., 2016) suggest that their mantle sources contained, respectively, $29 \%, 93-97 \%$, and roughly similar, HSE abundances compared to the modern mantle, yet Schapenburg samples have $\mu^{182} \mathrm{~W}$ of -6 to -12 ; Komati from 0 to +5 and Isua ultramafic rocks from 0 to +13 . The explanation for the range in $W$ isotopic composition in the mantle is further confounded by the observation that the range in $\mu^{182} \mathrm{~W}$ in modern intraplate volcanism (Mundl et al., 2017) is about the same as in the Archean, although the range of the modern mantle is offset to, on average, lower $\mu^{182} \mathrm{~W}$. 
Another problem with explaining the $\mathrm{W}$ isotope variability between Archean and modern rocks as reflecting the slow mixing of late accreted chondritic material into the mantle is that the range in $\mu^{142} \mathrm{Nd}$ seen in Hadean and Eoarchean rocks diminishes to barely measurable values by the end of the Archean (Fig. 19), and little if any variability in $\mu^{142} \mathrm{Nd}$ is seen in modern mantlederived rocks (Jackson and Carlson, 2012; Horan et al., 2018; Peters et al., 2018). The Nd data thus suggest that whatever compositional heterogeneity was present in the Hadean mantle was effectively mixed away by the end of the Archean. This observation, however, does not rule out a core contribution of $\mathrm{W}$ to the mantle through time, as there likely is not enough $\mathrm{Nd}$ in the core to create an observable signature in the mantle. For example, only $0.25 \%$ by weight core addition to the mantle would lower its $\mu^{182} \mathrm{~W}$ from +20 to 0 , assuming core and mantle $\mathrm{W}$ concentrations of 0.47 (McDonough, 2003) and 0.012 ppm (Palme and O'Neill, 2014), respectively and a core $\mu^{182} \mathrm{~W}=-200$ (Kleine et al., 2009), an amount that is within the range allowed by some minor and trace element constraints of mantle compositional variability through time (Jochum et al., 1993; Carlson et al., 2014b). Direct addition of core metal to the mantle, however, should produce a $\mu^{182} \mathrm{~W}$ versus HSE abundance relationship opposite to that observed in Archean rocks, so different alternatives must be considered. These include coremantle exchange occurring diffusively across the core-mantle boundary, allowing the core W isotope signature to be imparted on the mantle, while chemical equilibrium would keep the HSE in the core (Rizo et al., 2019). The exsolution of W-rich and HSE-poor oxides from the outer core are also expected due to secular core cooling and the increasing oxygen fugacity in the outer core due to inner core crystallization (Rizo et al., 2019). Another possibility is the incorporation into the source of mantle plumes of W-rich and HSE depleted metal droplets produced by early perovskite disproportionation (Mundl et al., 2017).

\section{FIGURE 19 HERE}

\section{6) The Origin and Nature of Earth's First Crust}

\section{1) Early differentiation, but a delayed start for crust formation?}

An inescapable conclusion provided by the data now available for short-lived radiometric systems in terrestrial rocks is that the Earth was compositionally heterogeneous within tens of millions of years of its formation. The variability in both ${ }^{142} \mathrm{Nd} /{ }^{144} \mathrm{Nd}$ and ${ }^{182} \mathrm{~W} /{ }^{184} \mathrm{~W}$ in Eo/Paleoarchean rocks shows that whatever geodynamic processes were occurring in the Hadean were not capable of erasing the signature of early $(>4.5 \mathrm{Ga}$ ) differentiation events. The earliest temporal constraint on this initial differentiation is provided by $\mathrm{Hf}-\mathrm{W}$ data given the 8.9 Ma half-life of ${ }^{182} \mathrm{Hf}$. As discussed in section 5, the lack of correlation of $\mu^{182} \mathrm{~W}$ and $\mu^{142} \mathrm{Nd}$ in ancient crustal rocks is most easily explained if the $\mathrm{Hf}-\mathrm{W}$ system is primarily tracking coremantle segregation, while the $\mathrm{Sm}-\mathrm{Nd}$ and Lu-Hf systems are controlled by crust-mantle differentiation that occurred after ${ }^{182} \mathrm{Hf}$ had become extinct. Using $\mathrm{Hf}-\mathrm{W}$ to constrain the time of terrestrial core formation depends on the details of Earth's growth (Nimmo and Agnor, 2006; Halliday, 2008; Rudge et al., 2010), but the non-chondritic ${ }^{182} \mathrm{~W} /{ }^{184} \mathrm{~W}$ of Earth's mantle requires that core-mantle separation was occurring within tens of millions of years after the start of 
Solar System formation (e.g. Kleine et al., 2002; Yin et al., 2002). A later start for differentiation of the silicate Earth is indicated by a number of radiometric systems (Carlson et al., 2015), particularly ${ }^{146} \mathrm{Sm}-{ }^{142} \mathrm{Nd}$, but also model ages from the evolution paths documented by initial $\varepsilon \mathrm{Hf}$ in Archean rocks that range from 4.4-4.5 Ga for Jack Hills (Kemp et al., 2010) and Nuvvuagittuq (O'Neil et al., 2013) to 4.1 to 4.2 Ga for Acasta (Reimink et al., 2019) and Kaapvaal. Most coupled ${ }^{143} \mathrm{Nd}-{ }^{142} \mathrm{Nd}$ model ages for early $\mathrm{Sm}-\mathrm{Nd}$ fractionation point to ages less than 4.5 Ga (Caro et al., 2006; Rizo et al., 2013; Morino et al., 2017; Saji et al., 2018). An intriguing option is that the $\mathrm{Nd}$ model ages reflect the time of the giant impact that created the Moon. Similar 4.35-4.45 Ga ages are obtained by many approaches to determining the age of the Moon (Nyquist et al., 1995; Boyet and Carlson, 2007; Brandon et al., 2009; Sprung et al., 2013; Carlson et al., 2014a; Gaffney and Borg, 2014; Borg et al., 2015). An impact the size of the Moon-forming event is unlikely to rehomogenize the core and mantle of the Earth, and hence not erase the $\mathrm{W}$ isotopic signature of early core formation in the mantle (Nimmo and Agnor, 2006; Halliday, 2008; Marchi et al., 2018). Such an impact, however, could have destroyed whatever crust existed on Earth at the time of impact and homogenized it back into the mantle (Marchi et al., 2014; Nakajima and Stevenson, 2015). In this case, the range observed in ${ }^{142} \mathrm{Nd} /{ }^{144} \mathrm{Nd}$ in Eoarchean rocks was created as a result of the differentiation of the mantle after the Moon-forming impact. That this range in $\mathrm{Nd}$ isotopic composition does not correlate with $\mathrm{W}$ isotope variation is most easily explained if the last terrestrial magma ocean formed after ${ }^{182} \mathrm{Hf}$ had become extinct. The same statement can be made for the Moon, where ${ }^{146} \mathrm{Sm}-{ }^{142} \mathrm{Nd}$ model ages for initial lunar differentiation are predominantly in the 4.35-4.45 Ga range (e.g. Borg et al., 2015), and there is no variation in ${ }^{182} \mathrm{~W} /{ }^{184} \mathrm{~W}$ that can be attributed to the decay of ${ }^{182} \mathrm{Hf}$ (Touboul et al., 2007).

\section{2) What was the nature of the first crust?}

If the outer portion of Earth was "reset" by the Moon-forming impact, the only materials preserved on Earth that come close to the age of this event are a small fraction of the zircons from Jack Hills that record ages up to $4.37 \mathrm{Ga}$ (Valley et al., 2014). While the zircons themselves appear to derive from intermediate to felsic composition rocks, the initial $\varepsilon \mathrm{Hf}$ of the Jack Hills zircons (Fig. 15), as well as those from all other early Archean cratons discussed here (Fig. 10,12), document $\mathrm{Hf}$ isotopic evolution with time consistent with protolith $\mathrm{Lu} / \mathrm{Hf}$ ratios more typical of mafic rocks than of Archean TTG. A mafic source for an Archean zircon-bearing TTG is no surprise as a basaltic composition rock, when melted under hydrous conditions, is a likely source to produce the type of felsic rocks that dominate Archean terranes (e.g. Arth and Barker, 1976; Martin, 1987; Martin, 1994; Adam et al., 2012; Moyen and Martin, 2012). The exact nature of this mafic crust, and particularly its mechanism of origin, is not robustly defined because so little, if any, of it still exists. A long-lived mafic Hadean crust, however, is also the most likely precursor of the Neoarchean TTG from the Superior Craton (O'Neil and Carlson, 2017). If the Ujaraaluk mafic supracrustal rocks are examples of such crust, their composition suggests a similar petrogenetic path to that of modern oceanic convergent margin settings (O'Neil et al., 2011; Turner et al., 2014). A similar petrogenetic path has been suggested for the Isua supracrustal rocks at circa 3.8 Ga (Polat et al., 2002; Hoffmann et al., 2010). The Isua rocks, however, were derived from a mantle source that was depleted in light REE around $4.4 \mathrm{Ga}$. If 
these mafic supracrustal rocks are representative of the type of mafic crust that served as the source for the oldest preserved terrestrial crust, the inference is that this mafic crust was not some highly fractionated material produced by magma ocean crystallization, e.g. a lunar KREEP analog, but was instead produced by shallow partial melting of upper mantle that had a major element composition not readily distinguishable from estimates of the source composition of modern mantle-derived volcanism.

\section{3) Was plate tectonics involved?}

When, and why, plate tectonics started on Earth remains a topic of debate, in part dependent on what characteristics one chooses to define a convergent plate margin setting in the rock record. The various structural features, such as paired metamorphic belts, blue schists, and ultra-high-pressure metamorphism (Stern, 2005) indicative of modern plate subduction are unlikely to be preserved through the pervasive later tectonism/metamorphism experienced by all ancient crustal terranes. Nevertheless, some structural features of Archean terranes have been interpreted as supporting their formation by subduction. One example is the Isua supracrustal belt where low-angle thrust faulting (Komiya et al., 1999) and the presence of dikes interpreted as a sheeted dike complex (Furnes et al., 2007) were interpreted as reflecting the formation of the Isua rocks in a tectonic setting similar to modern subduction zones in the western Pacific. Given the degree of strain linearization of structures in these metamorphosed terranes, however, such structural interpretations of tectonic setting are not unambiguous. Another argument for the presence of subduction in the early Earth comes from the combination of variable oxygen isotope composition, inclusion mineralogy, and temperatures of crystallization of the Hadean Jack Hills zircons that have been used to suggest that the source rocks for these zircons formed in a region with a cool geotherm, within the range typical of modern subduction zones (Hopkins et al., 2008, 2010). Compositional features of ancient rocks also have been used to suggest the tectonic setting of their petrogenesis. Boninitic composition rocks in the Phanerozoic are found only in convergent margin settings (e.g. Hickey and Frey, 1982). Although allowances have to be made for the element mobility that occurs during metamorphism, the supracrustal rocks at both Nuvvuagittuq and Isua include rocks with boninite-like compositions. Another compositional indicator of subduction zone magmatic products in the Phanerozoic are adakitic composition intermediate to felsic rocks. Adakites are rocks with compositional features such as high $\mathrm{Al}_{2} \mathrm{O}_{3}$ and $\mathrm{Sr}$ contents, but with strong depletion in the heavy REE that are usually interpreted as reflecting the melts of mafic source rocks at a pressure where garnet is a residual phase during melting (Defant and Drummond, 1990). Adakites may be produced by melting at the base of a thickened mafic crust, and hence are not uniquely associated with subduction, but the alternative is that they are produced by the melting of subducted mafic crust (Drummond and Defant, 1990). Given that modern adakites and ancient TTG, that are major components of most Archean terranes, share compositional characteristics, the mere presence of TTG in Archean terranes has been used as an argument that the major felsic component of Archean crust was produced by plate subduction (see e.g. Moyen and Martin (2012) for a review). 
A number of studies have noted changes in the rock record circa 3.0 to $3.5 \mathrm{Ga}$ that have been interpreted as marking the initiation of plate tectonics on Earth, which would imply that Earth's earliest crust was not produced in a convergent margin setting. These observations include the lack of eclogitic inclusions in diamonds older than 3.0 Ga (Shirey and Richardson, 2011), a dramatic change in composition and initial $\mathrm{Hf}$ and ${ }^{142} \mathrm{Nd}$ isotopic compositions of felsic rocks in Acasta at circa 3.5-3.6 Ga (Bauer et al., 2017; Reimink et al., 2018), a decrease in the rate of crustal growth at $3 \mathrm{Ga}$ interpreted to reflect the initiation of crust recycling via subduction (Cawood et al., 2013); the transition from a more mafic to felsic continental crust at circa 3.0 Ga (Dhuime et al., 2015; Tang et al., 2016), evidence for continental rifting in the Pilbara Craton at 3.2 Ga (Van Kranendonk et al., 2010) and a change in the global zircon Hf-isotope record in this time interval (Dhuime et al., 2015). While these observations provide strong evidence for plate-tectonic behavior after 3.0-3.6 Ga, whether they require the lack of plate subduction prior to this time is not clear. In addition, there is a continuing debate about whether these observations reflect changing rates of continental crust production or instead a decline in the rate of crustal recycling (e.g. Rosas and Korenaga, 2018). The compositional features of both the Isua and Nuvvagittuq supracrustal rocks have been interpreted as originating in a convergent margin setting, so this would push the initiation of subduction back to at least 3.8 $\mathrm{Ga}$ and possibly to $4.28 \mathrm{Ga}$ if the ${ }^{146} \mathrm{Sm}-{ }^{142} \mathrm{Nd}$ correlation shown by the Ujaraaluk dates the eruption of these rocks. Whether these rocks are testimony to long-lived subductions systems similar to those of modern convergent margins, or instead reflective of short-lived subduction initiation settings (e.g. Van Hunen and Moyen, 2012) is not clear.

Another avenue that has been used to evaluate the occurrence, or efficiency, of plate subduction has relied on the persistence of $\mu^{142} \mathrm{Nd}$ variability throughout at least the early Archean. For isotopic variability in the short-lived isotope systems to persist long after the extinction of the radioactive parent requires that the isotopically distinct components not be remixed to return to the average composition of the system. Figure 19 shows that the range in ${ }^{142} \mathrm{Nd}$ is maximum near $3.8 \mathrm{Ga}$ and diminishes to barely detectable in modern mantle-derived rocks. If the positive and negative end members in $\mu^{142} \mathrm{Nd}$ represent the complementary pair of Hadean incompatible element enriched crust and the residual incompatible element depleted mantle residue that was melted to produce that crust, then the range in $\mu^{142} \mathrm{Nd}$ at 3.8 Ga could reflect the participation of those two end members in creating Archean crustal rocks. If the two end members did not mix back together, then the isotopic distinction would persist throughout Earth history. This path appears to have been followed in the Hudson Bay terrane where the mafic basement evolved to negative $\mu^{142} \mathrm{Nd}$ by $3.8 \mathrm{Ga}$ and was remelted occasionally from then until $2.7 \mathrm{Ga}$. By the end of the Archean, with the exception of the Hudson Bay terrane, most igneous rocks were being produced from sources that had, at best, marginally resolvable differences in ${ }^{142} \mathrm{Nd} /{ }^{144} \mathrm{Nd}$. This was interpreted by Debaille et al. (2013) as reflecting stagnant-lid tectonics throughout much of the Hadean and Archean on the grounds that mixing rates in the upper mantle should have been fast enough to rehomogenize the mantle well before the end of the Archean. Similar models taking into account the grain-size effects on viscosity, suggest that the long-term (over $1 \mathrm{Ga}$ ) survival of early formed heterogeneities in the Archean mantle is possible with a mobile-lid regime (Foley and Rizo, 2017). These approaches, however, depend not only on the mixing rate of the mantle, but on the rate of recycling of 
crustal material into the mantle. For example, Rosas and Korenaga (2018) used a similar approach to conclude that large volumes of evolved crust existed in the Hadean and that these were effectively recycled into the mantle to be efficiently mixed with their chemical and isotopic compliment to erase the signature of ${ }^{142} \mathrm{Nd} /{ }^{144} \mathrm{Nd}$ variation by the end of the Archean. The ambiguity in these approaches is that we have no independent information on the volume of evolved crust in the Hadean, the volume and degree of incompatible element depletion of the mantle residual to that crust production, or the rate of crustal recycling.

\section{4) When was the depleted mantle formed?}

The modern global mid-ocean ridge volcanic system taps a mantle that shows the chemical and isotopic signature of the removal of continental crust (e.g. Hofmann, 1988). The isotopic characteristics of MORB and continental crust suggest an average age for the process of continental crust extraction from its complementary section of incompatible element depleted mantle of order 1.8 to $2 \mathrm{Ga}$ (Jacobsen and Wasserburg, 1979). In all likelihood, this midProterozoic age reflects nothing more than an average age for the process of crust formation and recycling that has been occurring over most of Earth history. The presence of Archean continental crust on Earth shows clearly that crust-mantle separation must have started well before the mid-Proterozoic. The earliest indisputable evidence for the existence of incompatible element depleted mantle is provided by the positive $\mu^{142} \mathrm{Nd}$ measured in Eoarchean rocks from Greenland (Boyet and Carlson, 2006; Caro et al., 2006; Bennett et al., 2007; Rizo et al., 2011; O’Neil et al., 2016; Rizo et al., 2016; Saji et al., 2018), Labrador (Canada) (Morino et al., 2017), and Anshan (China) (Li et al., 2017). To reach the average modern MORB $\varepsilon^{143} \mathrm{Nd}$ of +8 (Gale et al., 2013) would require a ${ }^{147} \mathrm{Sm} /{ }^{144} \mathrm{Nd}=0.21$ starting from chondritic ${ }^{143} \mathrm{Nd} /{ }^{144} \mathrm{Nd}$ at $4.567 \mathrm{Ga}$. This source would evolve a $\mu^{142} \mathrm{Nd}=+21$ (Fig. $5 \mathrm{c}$ ). This value would change to $7 \mathrm{ppm}$ if the reservoir with superchondritic Sm/Nd formed at $4.4 \mathrm{Ga}$ rather than $4.567 \mathrm{Ga}$ (Fig. $5 \mathrm{c}$ ). A superchondritic $\mathrm{Sm} / \mathrm{Nd}$ was proposed for the accessible mantle on the basis of a difference in ${ }^{142} \mathrm{Nd} /{ }^{144} \mathrm{Nd}$ between chondrites and modern mantle-derived volcanic rocks (Boyet and Carlson, 2005), but that interpretation has been questioned on the basis of evidence that the range in ${ }^{142} \mathrm{Nd} /{ }^{144} \mathrm{Nd}$ shown by different groups of chondrites is due to imperfect mixing of the various nucleosynthetic contributions to the elements that make up the Solar System (Andreasen and Sharma, 2006; Carlson et al., 2007; Gannoun et al., 2011; Bouvier and Boyet, 2016; Burkhardt et al., 2016; Fukai and Yokoyama, 2017). While there is no question that nucleosynthetic anomalies contribute to the ${ }^{142} \mathrm{Nd} /{ }^{144} \mathrm{Nd}$ variability in Solar System materials, the exact value of Earth's average ${ }^{142} \mathrm{Nd} /{ }^{144} \mathrm{Nd}$ is not sufficiently defined to rule out the option that at least a portion of the upper mantle's superchondritic ${ }^{142} \mathrm{Nd} /{ }^{144} \mathrm{Nd}$ reflects a superchondritic $\mathrm{Sm} / \mathrm{Nd}$ ratio in the accessible mantle. Indeed, the best estimates for bulk lunar $\mu^{142} \mathrm{Nd}$ are -6 to -9 (Sprung et al., 2013; Carlson et al., 2014a). If the Moon and Earth share similar ${ }^{142} \mathrm{Nd} /{ }^{144} \mathrm{Nd}$, then this value may be a reasonable approximation for the bulk-Earth, in which case $\mu^{142} \mathrm{Nd}=0$ is the signature of a Hadean source with superchondritic $\mathrm{Sm} / \mathrm{Nd}$.

The possibility thus exists that the portion of the mantle that has contributed to the generation of crustal rocks throughout Earth history has been characterized by superchondritic Sm/Nd since shortly after Earth formation. The extraction of the current volume of continental crust 
over Earth history has most certainly added to the incompatible element depletion of that portion of the mantle that contributed to crust formation, but the degree of extra depletion depends on the fraction of mantle involved in crust formation. If the chemical consequences of continent formation are distributed throughout the whole mantle, then extracting the current volume of continental crust, of average composition given by Rudnick and Gao (2003), would increase the ${ }^{147} \mathrm{Sm} /{ }^{144} \mathrm{Nd}$ of the mantle from 0.21 to 0.22 . If the $\mathrm{DM}$ is restricted only to the upper mantle, just by mass balance, the removal of continental crust would have a larger effect, raising its ${ }^{147} \mathrm{Sm} /{ }^{144} \mathrm{Nd}$ from 0.21 to 0.24 . Estimates of the modern-day composition of the source of MORB give ${ }^{147} \mathrm{Sm} /{ }^{144} \mathrm{Nd}$ between 0.228 (Salters and Stracke, 2004) and 0.249 (Workman and Hart, 2005).

The implication is that the fraction of the mantle that has supplied surface volcanism throughout Earth history may have become depleted in incompatible elements relative to estimates of the BSE composition shortly after Earth formation. This early DM thus is not the chemically complementary residue to continent extraction from the mantle (Boyet and Carlson, 2006; Carlson and Boyet, 2008). Both continental crust and DM show a depletion in some elements, notably $\mathrm{Nb}$ and Ta, compared to estimates of the BSE composition (Hofmann, 1988; Carlson and Ionov, 2019) that cannot be reconciled with the two-component mass balance of continental crust plus DM equals BSE. Some have suggested that the deficiency of the mantle in $\mathrm{Nb}$ reflects its incorporation into the core (e.g. Wade and Wood, 2001; Munker et al., 2017), but this explanation does not obviously explain the low BSE contents of Ta. If not in the core, the $\mathrm{Nb}$ and Ta depletion of the mantle is supporting evidence that the silicate Earth experienced a differentiation event before the extraction of continental crust began to deplete the mantle of incompatible elements. If so, there is no longer an expectation that the portion of the mantle that has supplied surface volcanism throughout Earth history need have chondritic relative abundances of refractory lithophile elements, such as $\mathrm{Nd}, \mathrm{Sm}$, Lu, and Hf. Rudnick et al. (2000) suggested that the missing $\mathrm{Nb}$ and Ta in the silicate Earth reflects separation of rutilebearing refractory eclogite from the mantle. As discussed in section 4, the majority of Archean/Hadean terranes examined here suggest an initial phase that involved reworking of a mafic crust to create the oldest felsic components of these cratons. An intriguing possibility is that the major portion of this early mafic crust was returned into Earth's interior, but segregated from its chemical complement in the mantle to create a DM that was significantly depleted in $\mathrm{Nb}$ and $\mathrm{Ta}$, but only mildly depleted in incompatible lithophile elements such as $\mathrm{Nd}$ and $\mathrm{Hf}$. For example, removal of $7 \%$ by weight of a mafic rock of composition similar to sample PC-162 of the Ujaraaluk (O'Neil et al., 2011) from the BSE of Palme and O'Neill (2014) will create a residue with present day ${ }^{147} \mathrm{Sm} /{ }^{144} \mathrm{Nd}=0.21,{ }^{176} \mathrm{Lu} /{ }^{177} \mathrm{Hf}=0.035$ and chondritenormalized $\mathrm{Nb} / \mathrm{La}=1.5$. If this residue was formed at $4.567 \mathrm{Ga}$, at $3.8 \mathrm{Ga}$ it would have had $\varepsilon^{143} \mathrm{Nd}=1.4, \varepsilon \mathrm{Hf}=1.1$ and $\mu^{142} \mathrm{Nd}=21$. If formed at $4.4 \mathrm{Ga}$, its isotopic composition at $3.8 \mathrm{Ga}$ would have been $\varepsilon^{143} \mathrm{Nd}=1.2, \varepsilon \mathrm{Hf}=0.7$, and $\mu^{142} \mathrm{Nd}=7$. This model thus would create a residue whose $\mathrm{Nd}$ and $\mathrm{Hf}$ isotope composition deviate from the $\mathrm{Hf}-\mathrm{Nd}$ array in the direction seen for many Eoarchean rocks. In this model, there is no requirement for significant volumes of highlydifferentiated crust, like the modern continental crust, to have existed in the Hadean. 
If the portion of the mantle involved in creating crustal rocks does, on average, have chondritic $\mathrm{Sm} / \mathrm{Nd}$ and $\mathrm{Lu} / \mathrm{Hf}$ ratios, then the positive $\varepsilon^{143} \mathrm{Nd}$ and $\varepsilon \mathrm{Hf}$ of at least some early Archean rocks, and the positive $\mu^{142} \mathrm{Nd}$ of the North Atlantic Craton and the Anshan Complex Eoarchean rocks could reflect the extraction of significant volumes of continent-like crust in the Hadean. Depending on the volume of depleted mantle produced as a consequence of this crust extraction, the isotope data for Archean rocks would then be supportive of geodynamic models that invoke large volumes of crust formation, and active recycling of most of that crust, within the first 1.5 billion years of Earth history (Rosas and Korenaga, 2018). This model would produce a DM-like mantle reservoir early in Earth history, whose average composition was kept essentially constant throughout Earth history by balancing the rates of crust generation and recycling. The model, however, does not explain the lack of signature of evolved crustal rocks as source rocks for Eoarchean crust, nor the $\mathrm{Nb}$ and Ta deficiency of the sum of continental crust and DM compared to a BSE with chondritic relative abundances of the refractory lithophile elements.

\subsection{What happened to the first crust?}

The isotopic characteristics of the ancient cratonic rocks discussed here provide different answers for the role of crustal reworking in their genesis. In the Hudson Bay terrane, the data suggest that a significant portion of this terrane was created by repeated remelting, or substantial assimilation, of a circa $4.3 \mathrm{Ga}$ mafic crust. The same appears to be true for both the oldest rocks of the Slave Craton and the sources of the Hadean zircons from Jack Hills. In these latter two examples, however, both terranes appear to have switched to more substantial, or even dominant (Reimink et al., 2019), creation of new crust from the mantle around 3.5-3.6 Ga. The northeastern Kaapvaal craton provides the other end member example of a craton created predominantly by new additions from the mantle, though the data allow some involvement of a Hadean, circa $4.1 \mathrm{Ga}$, mafic source, consistent with the discovery of detrital zircons of this age in the Kaapvaal sediments. Given that all of these terranes combined represent a small proportion of the present-day continental crust, one possible answer to the question at the head of this section is that there was not much evolved crust on the early Earth, and what was there is now a reworked component of the ancient preserved sections of continents. The alternative, however, is that the early Earth's surface was covered with mafic crust, a small portion of which was involved in remelting events that produced the oldest rocks of several of the existing cratons, but the majority of which was returned to Earth's interior via crustal recycling. The existence of unusually incompatible element depleted mantle sources for the North Atlantic Craton and the Anshan Complex, North China Craton, provides evidence that enough crust was extracted from the mantle circa 4.4-4.5 Ga to create a region of depleted mantle large enough to serve as source of these two cratons. That the positive $\mu^{142} \mathrm{Nd}$ is restricted to just these two cratonic blocks whereas most others show either zero or negative

$\mu^{142} \mathrm{Nd}$ suggests that this level of mantle depletion was not global in the Hadean/Eoarchean, and hence that the volume of evolved, continent-like, crust created in the Hadean may have been small.

\section{7) Conclusions}


Despite extensive efforts to find Earth's first crust, there are as yet no terrestrial rocks or minerals that yield ages as old as the age of the Earth. What we can learn about Earth's first crust thus must be inferred by interpretation of the information contained in the oldest preserved rocks. New insights on this subject are being gained by the improved ability to determine the initial isotopic composition for both the traditional long-lived radiometric systems and the newly utilized short-lived radiometric systems in Earth's oldest crustal rocks. The short-lived systems, in particular, are only sensitive to differentiation events that occurred in the Hadean and hence provide information on the nature of the sources from which Earth's oldest surviving crust formed. This information can be, and often is, distinct from that of the long-lived systems that have been integrating the chemical changes that have occurred to these commonly polymetamorphic rocks over billions of years. The data available suggests that different Hadean/Archean terranes were produced by a range of processes at different times. The fragments of the North Atlantic Craton in SW Greenland and Saglek share similar ancient incompatible element depleted mantle sources as does the Anshan Complex of China. Model ages for formation of the depleted mantle source from the ${ }^{146} \mathrm{Sm}-{ }^{142} \mathrm{Nd}$ system are about 4.4$4.5 \mathrm{Ga}$, and the apparent range in $\mathrm{Sm} / \mathrm{Nd}$ in the depleted portion of the mantle is similar to that seen today in the source of average MORB. If the Ujaraaluk supracrustal rocks are $4.3 \mathrm{Ga}$ in age, they too appear to have been derived from this depleted mantle. None of the most ancient preserved rocks on Earth appear to derive from reworking of highly evolved felsic crust. The Eo/Paleoarchean rocks of the northern Superior, Slave and Kaapvaal cratons appear to initially involve reworking of Hadean mafic crust with the Slave switching to something similar to modern convergent margin crustal growth from initially mantle-derived melts around 3.6 Ga. The isotopic distinction of the supracrustal rocks from Nuvvuagittuq and Isua, which have overlapping ranges in chemical composition, shows that similar rocks can be created from sources with very distinct histories. The persistence of isotopic variability in these short-lived systems after the extinction of the parent isotope provides a new avenue to investigate the rate of crust formation and recycling that occurred in the Hadean/Archean and the efficiency of mantle mixing in recombining these differentiated materials to minimize the signature of their existence. The lack of correlation between $\mu^{142} \mathrm{Nd}$ and $\mu^{182} \mathrm{~W}$ suggest that if Earth formed chemically distinct reservoirs through differentiation of a magma ocean prior to $4.5 \mathrm{Ga}$, the evidence for that event was erased from the mantle before $4.4 \mathrm{Ga}$, perhaps by vigorous mantle convection or alternatively by the mantle stirring caused by a late giant impact responsible for Moon formation. Both the ${ }^{182} \mathrm{Hf}_{-}{ }^{182} \mathrm{~W}$ and ${ }^{129}{ }^{12}{ }^{129} \mathrm{Xe}$ (e.g. Mukhopadhyay, 2012) systems provide evidence for Earth differentiation events prior to $4.5 \mathrm{Ga}$, but both systems may primarily record core-mantle separation, or in the case of I-Xe, early planetary outgassing, while the ${ }^{146} \mathrm{Sm}-{ }^{142} \mathrm{Nd}$ system tracks the beginnings of differentiation of the silicate Earth that started, or were reset by the Moon-forming impact, circa 4.4-4.45 Ga. The data for the oldest preserved crustal rocks suggest that the crust that existed in the Hadean was predominantly mafic, or at least not highly chemically differentiated. This primary mafic crust was remelted starting in the late Hadean to early Eoarchean to produce the types of felsic rocks that today typify continental crust. Several lines of evidence support a transition in the form of continental crust formation circa 3.0-3.5 Ga that may reflect the onset of modern style convergent margin magmatism, though evidence exists to suggest some form of transient crustal subduction prior to this time. 


\section{Acknowledgements:}

We thank Elis Hoffmann and Tsuyoshi lizuka for their detailed and insightful reviews and Catherine Chauvel for her efficient editorial handling of the paper.

\section{References}

Adam, J., Rushmer, T., O'Neil, J., and Francis, D. (2012) Hadean greenstones from the Nuvvuagittuq fold belt and the origin of the Earth's early continental crust. Geology 40, 363-366.

Amelin, Y. (2004) Sm-Nd systematics of zircon. Chemical Geology 211, 375-387.

Amelin, Y., Kamo, S. L., and Lee, D.-C. (2011) Evolution of early crust in chondritic or nonchondritic Earth inferred from U-Pb and Lu-Hf data for chemically abraded zircon from the Itsaq Gneiss Complex, West Greenland. Canadian Journal of Earth Science 48, 141160.

Amelin, Y. Lee, D.-C., and Halliday, A.N. (2000) Early-middle Archaean crustal evolution deduced from $\mathrm{Lu}-\mathrm{Hf}$ and $\mathrm{U}-\mathrm{Pb}$ isotopic studies of single zircon grains. Geochimica et Cosmochimica Acta 64, 4205-4225.

Amelin, Y., Lee, D.-C., Halliday, A. N., and Pidgeon, R. T. (1999) Nature of the Earth's earliest crust from hafnium isotopes in single detrital zircons. Nature 399, 252-255.

Andreasen, R., M.Sharma, Subbarao, K. V., and Viladkar, S. G. (2008) Where on Earth is the enriched Hadean reservoir. Earth and Planetary Science Letters 266, 14-28.

Andreasen, R. and Sharma, M. (2006) Solar nebula heterogeneity in p-process samarium and neodymium isotopes. Science 314, 806-809.

Armstrong, R. L., Taubeneck, W. H., and Hales, P. O. (1977) Rb-Sr and K-Ar geochronometry of Mesozoic granitic rocks and the Sr isotopic composition, Oregon, Washington and Idaho. Geological Society of America Bulletin 81, 3513-3536.

Arth, J. G. and Barker, F. (1976) Rare-earth partitioning between hornblende and dacitic liquid and implications for the genesis of trondhjemitic-tonalitic magmas. Geology 4, 534-536.

Baadsgaard, H., Collerson, K. D., and Bridgewater, D. (1979) The Archean gneiss complex of northern Labrador. 1. Preliminary U-Th-Pb geochronology. Canadian Journal of Earth Science 16, 951-961.

Baadsgaard, H. (1973) U-Th-Pb dates on zircons from the early Precambrian Amitsoq gneisses, Gothaab district, West Greenland. Earth and Planetary Science Letters 19, 22-28.

Bauer, A. M., Fisher, C. M., Vervoort, J. D., and Bowring, S. A. (2017) Coupled Lu-Hf and U-Pb isotopic analyses of the oldest terrestrial crust, the $>4.03 \mathrm{Ga}$ Acasta gneiss complex. Earth and Planetary Science Letters 458, 37-48.

Bea, F., Montero, P., Molina, J. F., Scarrow, J. H., Cambeses, A., and Moreno, J. A. (2018) Lu-Hf ratios of crustal rocks and their bearing on zircon $\mathrm{Hf}$ isotope model ages: the effects of accessories. Chemical Geology 484, 179-190.

Bell, E. A., Harrison, T. M., Kohl, I. E., and Young, E. D. (2014) Eoarchean crustal evolution of the Jack Hills zircon source and loss of Hadean crust. Geochimica et Cosmochimica Acta 146, 27-42. 
Bell, E. A., Harrison, T. M., McCulloch, M. T., and Young, E. D. (2011) Early Archean crustal evolution of the Jack Hills zircon source terrane inferred from $\mathrm{Lu}-\mathrm{Hf},{ }^{207} \mathrm{~Pb} /{ }^{206} \mathrm{~Pb}$, and $\delta^{18} \mathrm{O}$ systematics of Jack Hills zircons. Geochimica et Cosmochimica Acta 75, 4816-4829.

Belyatsky, B. V., Rodionov, N. V., Antonov, A. V., and Sergeev, S. A. (2011) The 3.98-3.63 Ga zircons as indicators of major processes operating in the ancient crust of the east Antarctic shield (Enderby Land). Doklady Earth Sciences 438, 770-774.

Bennett, V. C., Brandon, A. D., and Nutman, A. P. (2007) Coupled ${ }^{142} \mathrm{Nd}-{ }^{143} \mathrm{Nd}$ isotopic evidence for Hadean mantle dynamics. Science 318, 1907-1910.

Black, L. P., Gale, N. H., Moorbath, S., Pankhurst, R. J., and McGregor, V. R. (1971) Isotopic dating of very early Precambrian amphibolite facies gneisses from the Godthab district, West Greenland. Earth and Planetary Science Letters 59, 245-259.

Black, L. P., Williams, I. S., and Compston, W. (1986) Four zircon ages from one rock: the history of a 3930 Ma-old granulite from Mount Sones, Enderby Land, Antarctica. Contributions to Mineralogy and Petrology 94, 427-437.

Bleeker, W. (2003) The late Archean record: a puzzle in ca. 35 pieces. Lithos 71, 99-134.

Bleeker, W. and Davis, W. J. (1999) The 1991-1996 NATMAP Slave Province project introduction. Canadian Journal of Earth Science 36, 1033-1042.

Bleeker, W., Ketchum, J. W. F., Jackson, V. A., and Villeneuve, M. E. (1999) The Central Slave Basement Complex: Part 1. Its structural topology and autochthonous cover. Canadian Journal of Earth Science 36, 1083-1109.

Blichert-Toft, J. and Albarède, F. (2008) Hafnium isotopes in Jack Hills zircons and the formation of the Hadean crust. Earth and Planetary Science Letters 265, 686-702.

Blichert-Toft, J., Albarede, F., Rosing, M., Frei, R., and Bridgewater, D. (1999) The Nd and Hf isotopic evolution of the mantle through the Archean. Results from the Isua supracrustals, West Greenland, and from the Birimian terranes of West Africa. Geochimica et Cosmochimica Acta 63, 3901-3914.

Blichert-Toft, J., Arndt, N. T., Wilson, A., and Coetzee, G. (2015) Hf and Nd isotope systematics of early Archean komatiites from surface sampling and ICDP drilling in the Barberton Greenstone Belt, South Africa. American Mineralogist 100, 2396-2411.

Boehnke, P., Bell, E. A., Stephan, T., Trappitsch, R., Keller, C. B., Pardo, O. S., Davis, A. M., Harrison, T. M., and Palin, M. J. (2018) Potassic, high-silica Hadean crust. Proceedings of the National Academy of Sciences 115, 6353-6356.

Boily, M., Leclair, A., Maurice, C., Bedard, J. H., and David, J. (2009) Paleo- to Mesoarchean basement recycling and terrane definition in the Northeastern Superior Province, Quebec, Canada. Precambrian Research 168, 23-44.

Borg, L. E., Connelly, J. N., Boyet, M., and Carlson, R. W. (2011) Chronological evidence that the Moon is either young or did not have a global magma ocean. Nature 477, 70-73.

Borg, L. E., Gaffney, A. M., and Shearer, C. K. (2015) A review of lunar chronology revealing a preponderance of 4.34-4.37 Ga ages. Meteoritics and Planetary Science 50, 715-732.

Bouvier, A. and Boyet, M. (2016) Primitive solar system materials and Earth share a common initial ${ }^{142} \mathrm{Nd}$ abundance. Nature 537, 399-402.

Bouvier, A., Vervoort, J. D., and Patchett, P. J. (2008) The Lu-Hf and Sm-Nd isotopic composition of CHUR: Constraints from unequilibrated chondrites and implications for 
the bulk composition of terrestrial planets. Earth and Planetary Science Letters 273, 4857.

Bowring, S. A. and Housh, T. (1996) Sm-Nd isotopic data and Earth's evolution. Science 27, 1878-1879.

Bowring, S. A., Housh, T. B., and Isachsen, C. E. (1990) The Acasta gneisses; remnant of Earth's early crust. In: Newsom, H. E. and Jones, J. H. Eds.), The Origin of the Earth. Oxford University Press, New York.

Bowring, S. A. and Williams, I. S. (1999) Priscoan (4.00-4.03 Ga) orthogneisses from northwestern Canada. Contributions to Mineralogy and Petrology 134, 3-16.

Boyet, M., Blichert-Toft, J., Rosing, M., Storey, M., Télouk, P., and Albarède, F. (2003) ${ }^{142} \mathrm{Nd}$ evidence for early Earth differentiation. Earth and Planetary Science Letters 214, 427442.

Boyet, M. and Carlson, R. W. (2005) ${ }^{142} \mathrm{Nd}$ evidence for early (>4.53 Ga) global differentiation of the silicate Earth. Science 309, 576-581.

Boyet, M. and Carlson, R. W. (2006) A new geochemical model for the Earth's mantle inferred from ${ }^{146} \mathrm{Sm}^{-142} \mathrm{Nd}$ systematics. Earth and Planetary Science Letters 250, 254-268.

Boyet, M. and Carlson, R. W. (2007) A highly depleted moon or a non-magma ocean origin for the lunar crust? Earth and Planetary Science Letters 262, 505-516.

Brandon, A. D., Lapen, T. J., Debaille, V., Beard, B. L., Rankenburg, K., and Neal, C. (2009) Reevaluating ${ }^{142} \mathrm{Nd} /{ }^{144} \mathrm{Nd}$ in lunar mare basalts with implications for the early evolution and bulk Sm/Nd of the Moon. Geochimica et Cosmochimica Acta 73, 6421-6445.

Bridgewater, D., Collerson, K. D., Hurst, R. W., and Jesseau, C. W. (1975) Field characteristics of the early Precambrian rocks from Saglek, coast of Labrador. Geological Survey of Canada, Open File Report 75, 287-296.

Bridgewater, D. and Schiøtte, L. (1991) The Archean gneiss complex of northern Labrador. A review of current results, ideas and problems. Bulletin of the Geological Society of Denmark 39, 153-166.

Burkhardt, C., Borg, L. E., Brennecka, G. A., Shollenberger, Q. R., Dauphas, N., and Kleine, T. (2016) A nucleosynthetic origin for the Earth's anomalous ${ }^{142} \mathrm{Nd}$ composition. Nature 537, 394-398.

Byerly, B.L., Lowe, D.R., Drabon, N., Coble, M.A., Burns, D.H., Byerly, G.R. (2018) Hadean zircon from a 3.3 Ga sandstone, Barberton greenstone belt, South Africa. Geology 46, 967-970.

Card, K. D. (1990) A review of the Superior Province of the Canadian shield, a product of Archean accretion. Precambrian Research 48, 99-156.

Carlson, R. W., Borg, L. E., Gaffney, A. M., and Boyet, M. (2014a) Rb-Sr, Sm-Nd and Lu-Hf isotope systematics of the lunar Mg-suite: the age of the lunar crust and its relation to the time of Moon formation. Philosophical Transactions Royal Society of London A 372,

Carlson, R. W. and Boyet, M. (2008) Composition of Earth's interior: the importance of early events. Philosophical Transactions Royal Society of London A 366, 4077-4103.

Carlson, R. W., Boyet, M., and Horan, M. (2007) Chondrite barium, neodymium, and samarium isotopic heterogeneity and early earth differentiation. Science 316, 1175-1178.

Carlson, R. W., Boyet, M., O'Neil, J., Rizo, H., and Walker, R. J. (2015) Early differentiation and its long term consequences for Earth evolution. In: Badro, J. and Walter, M. Eds.), The Earth: Accretion and Differentiation. American Geophysical Union, Washington. 
Carlson, R. W., Garnero, E., Harrison, T. M., Li, J., Manga, M., McDonough, W. F., Mukhopadhyay, S., Romanowicz, B., Rubie, D., Williams, Q., and Zhong, S. (2014b) How did early Earth become our modern world? Annual Review of Earth and Planetary Sciences 42, 151-178.

Carlson, R. W., Hunter, D. R., and Barker, F. (1983) Sm-Nd age and isotopic systematics of the bimodal suite, ancient gneiss complex, Swaziland. Nature 305, 701-704.

Carlson, R. W. and Ionov, D. A. (2019) Compositional characteristics of the MORB mantle and bulk silicate Earth based on spinel peridotites from the Tariat Region, Mongolia. Geochimica et Cosmochimica Acta 257, 206-223.

Caro, G., Bennett, V. C., Bourdon, B., Harrison, T. M., Quadt, A. v., Mojzsis, S. J., and Harris, J. W. (2008) Application of precise ${ }^{142} \mathrm{Nd} /{ }^{144} \mathrm{Nd}$ analysis of small samples to inclusions in diamonds (Finsch, South Africa) and Hadean zircons (Jack Hills, Western Australia). Chemical Geology 247, 253-265.

Caro, G., Bourdon, B., Birck, J. L., and Moorbath, S. (2003) ${ }^{146} \mathrm{Sm}-{ }^{142} \mathrm{Nd}$ evidence from Isua metamorphosed sediments for early differentiation of the Earth's mantle. Nature 423, 428-432.

Caro, G., Bourdon, B., Wood, B.J., and Corgne, A. (2005) Trace-element fractionation in Hadean mantle generated by melt segregation from a magma ocean. Nature 246-249.

Caro, G., Bourdon, B., Birck, J. L., and Moorbath, S. (2006) High-precision ${ }^{142} \mathrm{Nd} /{ }^{144} \mathrm{Nd}$ measurements in terrestrial rocks: constraints on the early differentiation of the Earth's mantle. Geochimica et Cosmochimica Acta 70, 164-191.

Caro, G., Morino, P., Mojzsis, S. J., Cates, N. L., and Bleeker, W. (2017) Sluggish Hadean geodynamics: evidence from coupled ${ }^{146,147} \mathrm{Sm}-{ }^{142,143} \mathrm{Nd}$ systematics in Eoarchean supracrustal rocks of the Inukjuak domain (Quebec). Earth and Planetary Science Letters 457, 23-37.

Cates, N. L. and Mojzsis, S. J. (2007) Pre-3750 Ma supracrustal rocks from the Nuvvagittuq supracrustal belt, northern Quebec. Earth and Planetary Science Letters 255, 9-21.

Cavosie, A. J., Valley, J., and Wilde, S. (2019) The oldest terrestrial mineral record: thirty years of research on Hadean zircon from Jack Hills, Western Australia. In: Van Kranekdonk, M. J., Bennett, V. C., and Hoffmann, J. E. Eds., Earth's Oldest Rocks. Elsevier.

Cavosie, A. J., Valley, J. W., Wilde, S. A., and EIMF (2005) Magmatic $\delta^{18} \mathrm{O}$ in 4400-3900 Ma detrital zircons: a record of alteration and recycling of crust in the early Archaean. Earth and Planetary Science Letters 235, 663-681.

Cawood, P. A., Hawkesworth, C. J., and Dhuime, B. (2013) The continental record and the generation of continental crust. Geological Society of America, Bulletin 125, 14-32.

Chavagnac, V. (2004) A geochemical and Nd isotopic study of Barberton komatiites (South Africa): implication for the Archean mantle. Lithos 75, 253-281.

Chou, C.-L., Shaw, D. M., and Crocket, J. H. (1983) Siderophile trace elements in the Earth's oceanic crust and upper mantle. Journal of Geophysical Research 88, A507-A518.

Clemens, J. D., Yearron, L. M., and Stevens, G. (2006) Barberton (South Africa) TTG magmas: geochemical and experimental constraints on source-rock petrology, pressure of formation and tectonic setting. Precambrian Research 151, 53-78. 
Collerson, K. D. (1983) Ion microprobe zircon geochronology of the Uivak Gneiss: implication for the evolution of the early terrestrial crust in the North Atlantic craton, a cross section of Archean Crust. LPI Technical Report.

Collerson, K. D. and Bridgewater, D. (1979) Metamorphic development of early Archaean tonalitic and trondhjemitic gneisses, Saglek area, Labrador. In: Barker, F. (Ed.), Trondhjemites, Dacites and Related Rocks. Elsevier, Amsterdam.

Collerson, K. D., Campbell, L. M., Weaver, B. L., and Palacz, Z. A. (1991) Evidence for extreme mantle fractionation in early Archean ultramafic rocks from northern Labrador. Nature 349, 209-214.

Connelly, J. N., Bollard, J., and Bizzarro, M. (2017) Pb-Pb chronometer and the early Solar System. Geochimica et Cosmochimica Acta 201, 345-363.

Corgne, A., Liebske, C., Wood, B. J., Rubie, D. C., and Frost, D. J. (2005) Silicate perovskite-melt partitioning of trace elements and geochemical signature of a deep perovskitic reservoir. Geochimica et Cosmochimica Acta 69, 485-496.

Dale, C. W., Kruijer, T. S., and Burton, K. W. (2017) Highly siderophile element and ${ }^{182}$ W evidence for a partial late veneer in the source of $3.8 \mathrm{Ga}$ rocks from Isua, Greenland. Earth and Planetary Science Letters 458, 394-404.

Darling, J. R., Moser, D. E., L. Heaman, Davis, W. J., Stern, R., O'Neil, J., and Carlson, R. W. (2013) Hadean to Neoarchean evolution of the Nuvvuagittuq greenstone belt: new insights from U-Pb zircon geochronology. American Journal of Science 313, 844-876.

Davis, W. J., Gariepy, C., and Breemen, O. (1996) Pb isotopic composition of late Archaean granites and the extent of recycling of early Archaean crust in the Slave Province, northwest Canada. Chemical Geology 130, 255-269.

Davis, W. J. and Hegner, E. (1992) Neodymium isotopic evidence for the tectonic assembly of Late Archean crust in the Slave Province, northwest Canada. Contributions to Mineralogy and Petrology 111, 493-504.

de Leeuw, G. A. M., Ellam, R. M., Stuart, F. M., and Carlson, R. W. (2017) ${ }^{142} \mathrm{Nd} /{ }^{144} \mathrm{Nd}$ inferences on the nature and origin of the source of high ${ }^{3} \mathrm{He} /{ }^{4} \mathrm{He}$ magmas. Earth and Planetary Science Letters 472, 62-68.

Debaille, V., O'Neill, C., Brandon, A. D., Haenecour, P., Yin, Q.-Z., Mattielli, N., and Treiman, A. H. (2013) Stagnant-lid tectonics in early Earth revealed by ${ }^{142} \mathrm{Nd}$ variations in late Archean rocks. Earth and Planetary Science Letters 373, 83-92.

Defant, M. J. and Drummond, M. S. (1990) Derivation of some modern arc magmas by melting of young subducted lithosphere. Nature 347, 662-665.

Dhuime, B., Hawkesworth, C. J., Cawood, P. A., and Storey, C. D. (2012) A change in the geodynamics of continental growth 3 billion years ago. Science 335, 1334-1336.

Dhuime, B., Wuestefeld, A., and Hawkesworth, C. J. (2015) Emergence of modern continental crust about 3 billion years ago. Nature Geoscience 8, 552-555.

Diwu, C., Sun, Y., Wilde, S. A., Wang, H., Dong, Z., Zhang, H., and Q, W. (2013) New evidence for $\sim 4.45 \mathrm{Ga}$ terrestrial crust from zircon xenocrysts in Ordovician ignimbrite in the North Qinling orogenic belt, China. Gondwana Research 23, 1484-1490.

Drummond, M. S. and Defant, M. J. (1990) A model for trondhjemite-tonalite-dacite genesis and crustal growth through slab melting: Archean to modern comparisons. Journal of Geophysical Research 95, 21503-21521. 
Elkins-Tanton, L. T. (2011) Magma oceans in the inner solar system. Annual Review of Earth and Planetary Sciences 40, 113-139.

Fisher, C. M. and Vervoort, J. D. (2018) Using the magmatic record to constrain the growth of continental crust - the Eoarchean zircon Hf record of Greenland. Earth and Planetary Science Letters 488, 79-91.

Foley, B. J. and Rizo, H. (2017) Long-term preservation of early formed mantle heterogeneity by mobile lid convection: importance of grainsize evolution. Earth and Planetary Science Letters 475, 94-105.

Frei, R. and Jensen, B. K. (2003) Re-Os, Sm-Nd isotope- and REE systematics on ultramafic rocks and pillow basalts from the Earth's oldest oceanic crustal fragments (Isua Supracrustal Belt and Ujaragssuit Nunât area, W. Greenland). Chemical Geology 196, 163-191.

Frei, R., Polat, A., and Meibom, A. (2004) The Hadean upper mantle conundrum: evidence for source depletion and enrichment from $\mathrm{Sm}-\mathrm{Nd}$, Re-Os, and $\mathrm{Pb}$ isotopic compositions in 3.71 Gy boninite-like metabasalts from the Isua Supracrustal Belt, Greenland. Geochimica et Cosmochimica Acta 68, 1645-1660.

Froude, D. O., Ireland, T. R., Kinny, P. D., Williams, I. S., Compston, W., Williams, I. R., and Myers, J. S. (1983) Ion microprobe identification of 4100-4200 Myr old terrestrial zircons. Nature 304, 616-618.

Fukai, R. and Yokoyama T. (2017) Neodymium isotope heterogeneity of ordinary and carbonaceous chondrites and the origin of non-chondritic ${ }^{142} \mathrm{Nd}$ compositions in the Earth. Earth and Planetary Science Letters 474, 206-214.

Furnes, H., de Wit, M., Staudigel, H., Rosing, M., and Muehlenbachs, K. (2007) A vestige of Earth's oldest ophiolite. Science 315, 1704-1707.

Furnes, H., Robins, B., and DeWit, M. J. (2012) Geochemistry and petrology of lavas in the upper Onverwacht Suite, Barberton Mountain Land, South Africa. South African Journal of Geology 115, 171-210.

Gaffney, A. M. and Borg, L. E. (2014) A young solidification age for the lunar magma ocean. Geochimica et Cosmochimica Acta 140, 227-240.

Gale, A., Dalton, C. A., Langmuir, C. H., Sun, Y., and Schilling, J.-G. (2013) The mean composition of ocean ridge basalts. Geochemistry Geophysics Geosystems 14, 489-518.

Gannoun, A., Boyet, M., Rizo, H., and Goresy, A. E. (2011) ${ }^{146} \mathrm{Sm}-{ }^{142} \mathrm{Nd}$ systematics measured in enstatite chondrites reveals a heterogeneous distribution of ${ }^{142} \mathrm{Nd}$ in the solar nebula. Proceedings of the National Academy of Sciences 108, 7693-7697.

Garçon, M., Boyet, M., Carlson, R. W., Horan, M. F., Auclair, D., and Mock, T. D. (2018) Factors influencing the precision and accuracy of $\mathrm{Nd}$ isotope measurements by thermal ionization mass spectrometry. Chemical Geology 476, 493-514.

Garçon, M., Carlson, R. W., Shirey, S. B., Arndt, N. T., Horan, M., and Mock, T. (2017) Erosion of Archean continents: the Sm-Nd and Lu-Hf isotopic record of Barberton sedimentary rocks. Geochimica et Cosmochimica Acta 206, 216-235.

Gautam, I., Ray, J. S., Bhutani, R., Balakrishnan, S., and Dash, J. K. (2017) Role of fractionation correction in accurate determination of ${ }^{142} \mathrm{Nd} /{ }^{144} \mathrm{Nd}$ by TIMS: a case study of $1.48 \mathrm{Ga}$ alkaline rocks from Khariar, India. Chemical Geology 466, 479-490.

Goodwin, A. M. (1996) Principles of Precambrian Geology. Academic Press Limited, San Diego. 
Guitreau, M., Blichert-Toft, J., Mojzsis, S. J., A.S.G.Roth, and Bourdon, B. (2013) A legacy of Hadean silicate differentiation inferred from $\mathrm{Hf}$ isotopes in Eoarchean rocks of the Nuvvuagittuq supracrustal belt (Quebec, Canada). Earth and Planetary Science Letters 362, 171-181.

Guitreau, M., Blichert-Toft, J., Mojzsis, S. J., A.S.G.Roth, Bourdon, B., Cates, N. L., and Bleeker, W. (2014) Lu-Hf isotope systematics of the Hadean-Eoarchean Acasta gneiss complex (Northwest Territories, Canada). Geochimica et Cosmochimica Acta 135, 251-269.

Halliday, A. N. (2008) A young Moon-forming giant impact at 80-110 million years accompanied by late-stage mixing, core formation and degassing of the Earth. Proceedings of the Royal Society of London, Ser. A 366, 4163-4181.

Harper, C. L. and Jacobsen, S. B. (1992) Evidence from coupled ${ }^{147} \mathrm{Sm}_{-}{ }^{143} \mathrm{Nd}$ and ${ }^{146} \mathrm{Sm}-{ }^{142} \mathrm{Nd}$ systematics for very early (4.5-Gyr) differentiation of the Earth's mantle. Nature 360, 728-732.

Harrison, T. M. (2009) The Hadean Crust: Evidence from >4 Ga zircons. Annual Review of Earth and Planetary Sciences 37, 479-505.

Harrison, T. M., Blichert-Toft, J., Muller, W., Albèrede, F., Holden, P., and Mojzsis, S. J. (2005) Heterogeneous Hadean hafnium: evidence for continental crust at 4.4 to $4.5 \mathrm{Ga}$. Science 310, 1947-1950.

Harrison, T. M., Schmitt, A. K., McCulloch, M. T., and Lovera, O. M. (2008) Early (>4.5 Ga) formation of terrestrial crust: $\mathrm{Lu}-\mathrm{Hf}, \delta^{18} \mathrm{O}$, and Ti thermometry results for Hadean zircons. Earth and Planetary Science Letters 268, 476-486.

Hawkesworth, C. J. and Kemp, A. I. S. (2006) The differentiation and rates of generation of the continental crust. Chemical Geology 226, 134-143.

Hickey, R. L. and Frey, F. A. (1982) Geochemical characteristics of boninite series volcanics: implications for their source. Geochimica et Cosmochimica Acta 46, 2099-2115.

Hiess, J., Bennett, V. C., Nutman, A. P., and Williams, I. S. (2009) In situ U-Pb, O and Hf isotopic compositions of zircons and olivine from Eoarchean rocks, West Greenland: New insights to making old crust. Geochimica et Cosmochimica Acta 73, 4489-4516.

Hoffmann, J.E., and Wilson, A.H. (2017) The origin of highly radiogenic Hf isotopic compositions in $3.33 \mathrm{Ga}$ Commondale komatiite lavas (South Africa). Chemical Geology 455, 6-21.

Hoffmann, J. E., Kroner, A., Hegner, E., Viehmann, S., Xie, H., laccheri, L. M., Schneider, K. P., Hofmann, A., Wong, J., Geng, H., and J.Yang (2016) Source composition, fractional crystallization and magma mixing processes in the 3.48-3.43 Ga Tsawela tonalite suite (Ancient Gneiss Complex, Swaziland) - implications for Palaeoarchean geodynamcs. Precambrian Research 276, 43-66.

Hoffmann, J. E., Munker, C., Polat, A., Konig, S., Mezger, K., and Rosing, M. T. (2010) Highly depleted Hadean mantle reservoirs in the sources of early Archean arc-like rocks, Isua supracrustal belt, southern West Greenland. Geochimica et Cosmochimica Acta 74, 7236-7260.

Hoffmann, J.E., Munker, C., Naeraa, T., Rosing, M.T., Herwartz, D., Garbe-Schonberg, D., and Svahnberg, H. (2011a) Mechanisms of Archean crust formation inferred from highprecision HFSE systematics in TTGs. Geochimica et Cosmochimica Acta 75, 4157-4178. 
Hoffmann, J. E., Munker, C., Polat, A., Rosing, M. T., and Schulz, T. (2011b) The origin of decoupled $\mathrm{Hf}-\mathrm{Nd}$ isotope compositions in Eoarchean rocks from southern West Greenland. Geochimica et Cosmochimica Acta 75, 6610-6628.

Hoffmann, J. E., Nagel, T. J., Munker, C., Naeraa, T., and Rosing, M. T. (2014) Constraining the process of Eoarchean TTG formation in the Itsaq Gneiss Complex, southern West Greenland. Earth and Planetary Science Letters 388, 374-386.

Hoffmann, J. E., Zhang, C., Moyen, J. F., and Nagel, T. J. (2019) The formation of tonalitestrondhjemite-granodiorites in early continental crust. In: Van Kranekdonk, M. J., Bennett, V. C., and Hoffmann, J. E. Eds.), Earth's Oldest Rocks. Elsevier, Amsterdam.

Hofmann, A. W. (1988) Chemical differentiation of the Earth: the relationship between mantle, continental crust, and oceanic crust. Earth and Planetary Science Letters 90, 297-314.

Hopkins, M., Harrison, T. M., and Manning, C. E. (2008) Low heat flow inferred from $>4$ Gyr zircons suggests Hadean plate boundary interactions. Nature 456, 493-496.

Hopkins, M., Harrison, T.M., and Manning, C.E. (2010) Constraints on Hadean geodynamics from mineral inclusions in >4 Ga zircons. Earth and Planetary Science Letters 298, 367376.

Horan, M. F., Carlson, R. W., Walker, R. J., Jackson, M., Garçon, M., and Norman, M. (2018) Tracking Hadean processes in modern basalts with 142-Neodymium. Earth and Planetary Science Letters 484, 184-191.

lizuka, T., Horie, K., Komiya, T., Maruyama, S., Hirata, T., Hidaka, H., and Windley, B. F. (2006) 4.2 Ga zircon xenocryst in an Acasta gneiss from northwestern Canada: evidence for early continental crust. Geology 34, 245-248.

lizuka, T., Komiya, T., Johnson, S. P., Kon, Y., Maruyama, S., and Hirata, T. (2009) Reworking of Hadean crust in the Acasta gneisses, northwestern Canada: evidence from in situ Lu-Hf isotope analysis of zircon. Chemical Geology 259, 230-239.

lizuka, T., Komiya, T., Ueno, Y., Katayama, I., Uehara, Y., Maruyama, S., Hirata, T., Johnson, S. P., and Dunkley, D. J. (2007) Geology and zircon geochronology of the Acasta Gneiss Complex, northwestern Canada: new constraints on its tectonothermal history. Precambrian Research 153, 179-208.

Isachen, C. E. and Bowring, S. A. (1994) Evolution of the Slave craton. Geology 22, 917-920.

Isachen, C. E., Bowring, S. A., and Padgham, W. A. (1991) U-Pb zircon geochronology of the Yellowknife volcanic belt, NWT, Canada: New constraints on the timing and duration of greenstone belt magmatism. Journal of Geology 99, 55-67.

Ishikawa, A., Suzuki, K., Collerson, K. D., Liu, J., Pearson, D. G., and Komiya, T. (2017) Rheniumosmium isotopes and highly siderophile elements in ultramafic rocks from the Eoarchean Saglek Block, northern Labrador, Canada: implications for Archean mantle evolution. Geochimica et Cosmochimica Acta 216, 286-311.

Jackson, M. G. and Carlson, R. W. (2012) Homogeneous superchondritic ${ }^{142} \mathrm{Nd} /{ }^{144} \mathrm{Nd}$ in midocean ridge basalt and ocean island basalt mantle. Geochemistry Geophysics Geosystems 13,

Jacobsen, S. B. and Wasserburg, G. J. (1979) The mean age of mantle and crustal reservoirs. Journal of Geophysical Research 84, 7411-7427.

Jochum, K. P., Hofmann, A. W., and Seufert, H. M. (1993) Tin in mantle-derived rocks: constraints on Earth evolution. Geochimica et Cosmochimica Acta 57, 3585-3595. 
Kato, T., Ringwood, A. E., and Irifune, T. (1988) Experimental determination of element partitioning between silicate perovskites, garnets and liquids: constraints on early differentiation of the mantle. Earth and Planetary Science Letters 89, 123-145.

Kemp, A. I. S., Foster, G. L., Schersten, A., Whitehouse, M. J., Darling, J., and Storey, C. (2009) Concurrent $\mathrm{Pb}-\mathrm{Hf}$ isotope analysis of zircon by laser ablation multi-collector ICP-MS, with implications for the crustal evolution of Greenland and the Himalayas. Chemical Geology 261, 244-260.

Kemp, A. I. S., Whitehouse, M. J., and Vervoort, J. D. (2019) Deciphering the zircon Hf isotope systematics of Eoarchean gneisses from Greenland: Implications for ancient crustmantle differentiation and $\mathrm{Pb}$ isotope controversies. Geochimica et Cosmochimica Acta 250, 76-97.

Kemp, A. I. S., Wilde, S. A., Hawkesworth, C. J., Coath, C. D., Nemchin, A., Pidgeon, R. T., Vervoort, J. D., and DuFrane, S. A. (2010) Hadean crustal evolution revisited: New constraints from $\mathrm{Pb}-\mathrm{Hf}$ isotope systematics of the Jack Hills zircons. Earth and Planetary Science Letters 296, 45-56.

Ketchum, J. W. F., Bleeker, W., and Stern, R. A. (2004) Evolution of an Archean basement complex and its autochthonous cover, southern Slave Province, Canada. Precambrian Research 135, 149-176.

Kistler, R. W. and Peterman, Z. E. (1973) Variations in Sr, Rb, K, Na, and Initial ${ }^{87} \mathrm{Sr} /{ }^{86} \mathrm{Sr}$ in Mesozoic granitic rocks and intruded wall rocks in Central California. Geological Society of America, Bulletin 84, 3489-3512.

Kleine, T., Munker, C., Mezger, K., and Palme, H. (2002) Rapid accretion and early core formation on asteroids and the terrestrial planets from Hf-W chronometry. Nature 418, 952-955.

Kleine, T., Touboul, M., Bourdon, B., Nimmo, F., Mezger, K., Palme, H., Jacobsen, S. B., Yin, Q. Z., and Halliday, A. N. (2009) Hf-W chronology of the accretion and early evolution of asteroids and terrestrial planets. Geochimica et Cosmochimica Acta 73, 5150-5188.

Komiya, T., Maruyama, S., Masuda, T., Nohda, S., Hayashi, M., and Okamoto, K. (1999) Plate tectonics at 3.8-3.7 Ga: field evidence from the Isua accretionary complex, southern West Greenland. The Journal of Geology 107, 515-554.

Komiya, T., Yamamoto, S., Aoki, S., Koshida, K., Shimojo, M., Sawaki, Y., Aoki, K., Sakata, S., Yokoyama, T. D., Maki, K., Ishikawa, A., Hirata, T., and Collerson, K. D. (2017) A prolonged granitoid formation in Saglek Block, Labrador: zonal growth and crustal reworking of continental crust in the Eoarchean. Geoscience Frontiers 8, 355-385.

Kring, D. A. and Cohen, B. A. (2002) Cataclysmic bombardment throughout the inner solar system 3.9-4.0 Ga. Journal of Geophysical Research - Planets, doi:10.1029/2001JE001529.

Kroner, A., Hegner, E., Wendt, J. I., and Byerly, G. R. (1996) The oldest part of the Barberton granitoid-greenstone terrane, South Africa: evidence for crust formation events between 3.5 and 3.7 Ga. Precambrian Research 78, 105-124.

Kroner, A., Hoffmann, J. E., Xie, H., Munker, C., Hegner, E., Wan, Y., Hofmann, A., Liu, D., and Yang, J. (2014) Generation of early Archean grey gneisses through crustal melting of older crust in the eastern Kaapvaal craton, southern Africa. Precambrian Research 255, 833-846. 
Kroner, A., Hoffmann, J. E., Xie, H., Wu, F., Munker, C., Hegner, E., Wong, J., Wan, Y., and Liu, D. (2013) Generation of early Archaean felsic greenstone volcanic rocks through crustal melting in the Kaapvaal craton, southern Africa. Earth and Planetary Science Letters 381, 188-197.

Kroner, A. and Tegtmeyer, A. (1994) Gneiss-greenstone relationships in the Ancient Gneiss Complex of southwestern Swaziland, southern Africa, and implications fo early crustal evolution. Precambrian Research 67, 109-139.

Kruijer, T.S., and Kleine, T. (2017) Tungsten isotopes and the origin of the Moon. Earth and Planetary Science Letters 475, 15-24.

Kusiak, M. A., Whitehouse, M. J., Wilde, S. A., Dunkley, D. J., Menneken, M., Nemchin, A. A., and Clark, C. (2014) Changes in zircon chemistry during Archean UHT metamorphism in the Napier Complex, Antarctica. Amer. J. Sci. 313, 933-967.

Lahaye, Y., Arndt, N. T., Byerly, G. R., Chauvel, C., Fourcade, S., and Gruau, G. (1995) The influence of alteration on the trace-element and $\mathrm{Nd}$ isotopic compositions of komatiites. Chemical Geology 126, 43-64.

Li, C.-F., Wang, X.-C., Wilde, S. A., Li, X.-H., Wang, Y.-F., and Li, Z. (2017) Differentiation of the early silicate Earth as recorded by ${ }^{142} \mathrm{Nd}-{ }^{143} \mathrm{Nd}$ in $3.80-3.0 \mathrm{Ga}$ rocks from the Anshan Complex, North China Craton. Precambrian Research 301, 86-101.

Liang, W. H., Liang, C., Yong, S., XiaoMing, L., XueYi, X., JuanLu, C., Hong, Z., and ChunRong, D. (2007) 4.1 Ga xenocrystal zircon from Ordivician volcanic rocks in western part of North Qinling orogenic belt. Chinese Science Bulletin 52, 3002-3010.

Liu, D., Wilde, S. A., Wan, Y., Wu, J., Zhou, H., Dong, C., and Yin, X. (2008) New U-Pb and Hf isotopic data confirm Anshan as the oldest preserved segment of the North China Craton. American Journal of Science. 308, 200-231.

Liu, J., Touboul, M., Ishikawa, A., Walker, R. J., and Pearson, D. G. (2016) Widespread tungsten isotope anomalies and $\mathrm{W}$ mobility in crustal and mantle rocks of the Eoarchean Saglek Block, northern Labrador, Canada: implications for early Earth processes and W recycling. Earth and Planetary Science Letters 448, 13-23.

Maier, W. D., Barnes, S. J., Campbell, I. H., Fiorentini, M. L., P.Peltonen, Barnes, S. J., and Smithies, R. H. (2009) Progressive mixing of meteoritic veneer into the early Earth's deep mantle. Nature 460, 620-623.

Marchi, S., Bottke, W. F., Elkins-Tanton, L. T., Bierhaus, M., Wuennemann, K., Morbidelli, A., and Kring, D. A. (2014) Widespread mixing and burial of Earth's Hadean crust by asteroid impacts. Nature 511, 578-582.

Marchi, S., Canup, R. M., and Walker, R. J. (2018) Heterogeneous delivery of silicate and metal to the Earth by large planetesimals. Nature Geoscience 11, 77-81.

Marks, N. E., Borg, L. E., Hutcheon, I. D., Jacobsen, B., and Clayton, R. N. (2014) Samariumneodymium chronology and rubidium-strontium systematics of an Allende calciumaluminum-rich inclusion with implications for ${ }^{146} \mathrm{Sm}$ half-life. Earth and Planetary Science Letters 405, 15-24.

Martin, H. (1987) Petrogenesis of Archean trondhjemites, tonalites and granodiorites from Eastern Finland: major and trace element geochemistry. Journal of Petrology 28, 921953. 
Martin, H. (1994) The Archean grey gneisses and the genesis of continental crust. In: Condie, K. C. (Ed.), Archean Crustal Evolution. Elsevier, Amsterdam.

McCulloch, M. T. and Gamble, J. A. (1991) Geochemical and geodynamical constraints on subduction zone magmatism. Earth and Planetary Science Letters 102, 358-374.

McDonough, W. F. (2003) Compositional model for the Earth's core. In: Carlson, R. W. (Ed.), Treatise on Geochemistry. Elsevier, Amsterdam.

Mojzsis, S. J., Harrison, T. M., and Pidgeon, R. T. (2001) Oxygen-isotope evidence from ancient zircons for liquid water at Earth's surface 4,300 Myr ago. Nature 409, 178-180.

Moorbath, S. and Whitehouse, M. J. (1996) Sm-Nd isotopic data and Earth's evolution. Science 27, 1878.

Morino, P., Caro, G., and Reisberg, L. (2018) Differentiation mechanisms of the early Hadean mantle: insights from combined ${ }^{176} \mathrm{Hf}-{ }^{142,143} \mathrm{Nd}$ signatures of Archean rocks from the Saglek Block. Geochimica et Cosmochimica Acta 240, 43-63.

Morino, P., Caro, G., Reisberg, L., and Schumacher, A. (2017) Chemical stratification in the postmagma ocean Earth inferred from coupled ${ }^{146,147} \mathrm{Sm}-{ }^{142,143} \mathrm{Nd}$ systematics in ultramafic rocks of the Saglek block (3.25 - 3.9 Ga; northern Labrador, Canada). Earth and Planetary Science Letters 463, 136-150.

Moyen, J.-F. and Martin, H. (2012) Forty years of TTG research. Lithos 148, 312-336.

Mukhopadhyay, S. (2012) Early differentiation and volatile accretion recorded in deep-mantle neon and xenon. Nature 486, 101-104.

Mueller, P. A., Wooden, J. L., and Nutman, A. P. (1992) 3.96 Ga zircons from an Archean quartzite, Beartooth Mountains, Montana. Geology 20, 327-330.

Mundl, A., Touboul, M., Jackson, M. G., Day, J. M. D., Kurz, M. D., Lekic, V., Helz, R. T., and Walker, R. J. (2017) Tungsten-182 heterogeneity in modern ocean island basalts. Science 356, 66-69.

Mundl, A., Walker, R. J., Reimink, J. R., Rudnick, R. L., and Gashnig, R. M. (2018) Tungsten-182 in the upper continental crust: evidence from glacial diamictites. Chemical Geology 494, 144-152.

Murphy, D. T., Brandon, A. D., Debaille, V., Burgess, R., and Ballentine, C. (2010) In search of a hidden long-term isolated sub-chondritic ${ }^{142} \mathrm{Nd} /{ }^{144} \mathrm{Nd}$ reservoir in the deep mantle: Implications for the Nd isotope systematics of the Earth. Geochimica et Cosmochimica Acta 74, 738-750.

Naeraa, T., Schersten, A., Rosing, M. T., Kemp, A. I. S., Hoffmann, J. E., Kokfelt, T. F., and Whitehouse, M. J. (2012) Hafnium isotope evidence for a transition in the dynamics of continental growth 3.2 Gyr ago. Nature 485, 627-630.

Nakajima, M. and Stevenson, D. J. (2015) Melting and mixing states of the Earth's mantle after the Moon-forming impact. Earth and Planetary Science Letters 427, 286-295.

Nebel, O., Rapp, R. P., and Yaxley, G. M. (2014) The role of detrital zircons in Hadean crustal research. Lithos 190-191, 313-327.

Nimmo, F. and Agnor, C. B. (2006) Isotopic outcomes of N-body accretion simulations: Constraints on equilibration processes during large impacts from $\mathrm{Hf} / \mathrm{W}$ observations. Earth and Planetary Science Letters 243, 26-43. 
Norman, M. D. (2019) Origin of the Earth and the late heavy bombardment. In: Van Kranekdonk, M. J., Bennett, V. C., and Hoffmann, J. E. Eds.), Earth's Oldest Rocks. Elsevier, Amsterdam.

Nutman, A. P., Bennett, V. C., Friend, C. R. L., Hidaka, H., Yi, K., Lee, S. R., and Kamiichi, T. (2013) The Itsaq gneiss complex of Greenland: episodic 3900-3660 Ma juvenile crust formation and recycling in the 3660 to 3600 Ma Isukasian orogeny. American Journal of Science 313, 877-911.

Nutman, A. P., Bennett, V. C., Friend, C. R. L., and Rosing, M. T. (1997) 3710 and > 3790 Ma volcanic sequences in the Isua (Greenland) supracrustal belt; structural and Nd isotope implications. Chemical Geology 141, 271-287.

Nutman, A. P., Fryer, B. J., and Bridgewater, D. (1989) The early Archaean Nulliak (supracrustal) assemblage, norther Labrador. Canadian Journal of Earth Science 26, 2159-2168.

Nyquist, L. E., Wiesmann, H., Bansal, B., Shih, C.-Y., Keith, J. E., and Harper, C. L. (1995) ${ }^{146} \mathrm{Sm}-$ ${ }^{142} \mathrm{Nd}$ formation interval for the lunar mantle. Geochimica et Cosmochimica Acta 59, 2817-2837.

O'Neil, J., Boyet, M., Carlson, R. W., and Paquette, J.-L. (2013) Half a billion years of reworking of Hadean mafic crust to produce the Nuvvuagittuq Eoarchean felsic crust. Earth and Planetary Science Letters 379, 13-25.

O'Neil, J. and Carlson, R. W. (2017) Building Archean cratons from Hadean mafic crust. Science 355, 1199-1202.

O'Neil, J., Carlson, R. W., Francis, D., and Stevenson, R. K. (2008) Neodymium-142 evidence for Hadean mafic crust. Science 321, 1828-1831.

O'Neil, J., Carlson, R. W., Paquette, J.-L., and Francis, D. (2012) Formation age and metamorphic history of the Nuvvuagittuq greenstone belt. Precambrian Research 220-221, 23-44.

O'Neil, J., Francis, D., and Carlson, R. W. (2011) Implications of the Nuvvuagittuq greenstone belt for the formation of Earth's early crust. Journal of Petrology 52, 985-1009.

O'Neil, J., Maurice, C., Stevenson, R. K., Larocque, J., Cloquet, C., David, J., and Francis, D. (2007) The geology of the $3.8 \mathrm{Ga}$ Nuvvuagittuq (Porpoise Cove) greenstone belt, northeastern Superior Province, Canada. In: Van Kranekdonk, M. J., Smithies, R. H., and Bennett, V. C. Eds.), Earth's Oldest Rocks. Elsevier, Amsterdam.

O'Neil, J., Carlson, R. W., Papineau, D., Levine, E. Y., and Francis, D. (2019) The Nuvvuagittuq greenstone belt: a glimpse of Earth's earliest crust. In: Van Kranekdonk, M. J., Bennett, V. C., and Hoffman, J. E. Eds.), Earth's Oldest Rocks. Elsevier, Amsterdam.

O'Neil, J., Rizo, H., Boyet, M., Carlson, R. W., and Rosing, M. T. (2016) Geochemistry and Nd isotopic characteristics of Earth's Hadean mantle and primitive crust. Earth and Planetary Science Letters 442, 194-205.

Palme, H. and O'Neill, H. S. C. (2014) Cosmochemical estimates of mantle composition. In: Carlson, R. W. (Ed.), Treatise on Geochemistry. Elsevier, Amsterdam.

Paquette, J.-L., Barbosa, J. S. F., Rohais, S., Cruz, S. C. P., Goncalves, P., Peucat, J. J., Leal, A. B. M., Santos-Pinto, M., and Martin, H. (2015) The geological roots of South America: 4.1 Ga and 3.7 Ga zircon crystals discovered in N.E. Brazil and N.W. Argentina. Precambrian Research 271, 49-55.

Patterson, C. (1956) Age of meteorites and the Earth. Geochimica et Cosmochimica Acta 10, 230. 
Peters, B. J., Carlson, R. W., Day, J. M. D., and Horan, M. F. (2018) Hadean silicate differentiation preserved by anomalous ${ }^{142} \mathrm{Nd} /{ }^{144} \mathrm{Nd}$ ratios in the Reunion hotspot source. Nature 555 , 89-93.

Polat, A., Hofmann, A. W., and Rosing, M. T. (2002) Boninite-like volcanic rocks in the 3.7-3.8 Ga Isua greenstone belt, West Greenland; geochemical evidence for intra-oceanic subduction zone processes in the early Earth. Chemical Geology 184, 231-254.

Puchtel, I. S., Blichert-Toft, J., Touboul, M., Horan, M. F., and Walker, R. J. (2016) The coupled ${ }^{182} \mathrm{~W}-{ }^{142} \mathrm{Nd}$ record of early terrestrial mantle differentiation. Geochemistry, Geophysics, Geosystems 17, 2168-2193.

Puchtel, I. S., Blichert-Toft, J., Touboul, M., and Walker, R. J. (2018) ${ }^{182} \mathrm{~W}$ and HSE constraints from $2.7 \mathrm{Ga}$ komatiites on the heterogeneous nature of the Archean mantle. Geochimica et Cosmochimica Acta 228, 1-26.

Puchtel, I. S., Blichert-Toft, J., Touboul, M., Walker, R. J., Byerly, G. R., Nisbet, E. G., and Anhaeusser, C. R. (2013) Insights into early Earth from Barberton komatiites: evidence from lithophile isotope and trace element systematics. Geochimica et Cosmochimica Acta 108, 63-90.

Puchtel, I. S., Walker, R. J., Touboul, M., Nisbet, E. G., and Byerly, G. R. (2014) Insights into early Earth from the Pt-Re-Os isotope and highly siderophile element abundance systematics of Barberton komatiites. Geochimica et Cosmochimica Acta 125, 394-413.

Qin, L. and Carlson, R. W. (2016) Nucleosynthetic isotope anomalies and their cosmochemical significance. Geochemical Journal 50, 43-65.

Regelous, M. and Collerson, K. D. (1996) ${ }^{147} \mathrm{Sm}-{ }^{143} \mathrm{Nd},{ }^{146} \mathrm{Sm}-{ }^{142} \mathrm{Nd}$ systematics of early Archean rocks and implications for crust-mantle evolution. Geochimica et Cosmochimica Acta 60, 3513-3520.

Reimink, J. R., Chacko, T., Carlson, R. W., Shirey, S. B., Liu, J., Stern, R. A., Bauer, A. M., Pearson, D. G., and Heaman, L. M. (2018) Petrogenesis and tectonics of the Acasta Gneiss Complex derived from integrated petrology and ${ }^{142} \mathrm{Nd}$ and ${ }^{182} \mathrm{~W}$ extinct nuclidegeochemistry. Earth and Planetary Science Letters 494, 12-22.

Reimink, J. R., Chacko, T., Stern, R. A., and Heaman, L. M. (2016a) The birth of a cratonic nucleus: lithogeochemical evolution of the 4.02-2.94 Ga Acasta Gneiss Complex. Precambrian Research 281, 453-472.

Reimink, J. R., Davies, J. H. F. L., Chacko, T., Stern, R. A., Heaman, L. M., Pearson, D. G., Sarkar, C., Schaltegger, U., and Creaser, R. A. (2016b) No evidence for Hadean continents within Earth's oldest known zircon bearing unit. Nature Geoscience 9, 777-780.

Reimink, J. R., Pearson, D. G., Shirey, S. B., Carlson, R. W., and Ketchum, J. W. F. (2019) Onset of new, progressive crustal growth in the central Slave craton at $3.5 \mathrm{Ga}$. Geochemical Perspectives Letters 10, 8-13.

Rizo, H., Andrault, D., Bennett, N., Humayun, M., Brandon, A., Vlastellic, I., Moine, B., Poirer, A., Bouhifd, A. M., and Murphy, D. T. (2019) ${ }^{182} \mathrm{~W}$ evidence for core-mantle interaction in the source of mantle plumes. Geochemical Perspectives Letters 11, 6-11.

Rizo, H., Boyet, M., Blichert-Toft, J., O'Neil, J., Rosing, M. T., and Paquette, J.-L. (2012) The elusive Hadean enriched reservoir revealed by ${ }^{142} \mathrm{Nd}$ deficits in Isua Archaean rocks. Nature 491, 96-100. 
Rizo, H., Boyet, M., Blichert-Toft, J., and Rosing, M. (2011) Combined Nd and Hf isotope evidence for deep-seated source of Isua lavas. Earth and Planetary Science Letters 312, 267-279.

Rizo, H., Boyet, M., Blichert-Toft, J., and Rosing, M. T. (2013) Early mantle dynamics inferred from ${ }^{142} \mathrm{Nd}$ variations in Archean rocks from southwest Greenland. Earth and Planetary Science Letters 377-378, 324-335.

Rizo, H., Walker, R. J., Carlson, R. W., Touboul, M., Horan, M. F., Puchtel, I. S., Boyet, M., and Rosing, M. T. (2016) Early Earth differentiation investigated through ${ }^{142} \mathrm{Nd}$, ${ }^{182} \mathrm{~W}$, and highly siderophile element abundances in samples from Isua, Greenland. Geochimica et Cosmochimica Acta 175, 319-336.

Rosas, J. C. and Korenaga, J. (2018) Rapid crustal growth and efficient crustal recycling in the early Earth: implications for Hadean and Archean geodynamics. Earth and Planetary Science Letters 494, 42-49.

Roth, A. S. G., Bourdon, B., Mojzsis, S. J., Rudge, J. F., Guitreau, M., and Blichert-Toft, J. (2014) Combined ${ }^{147,146} \mathrm{Sm}-{ }^{143,142} \mathrm{Nd}$ constraints on the longevity and residence time of early terrestrial crust. Geochemistry Geophysics Geosystems 15, 2329-2345.

Roth, A. S. G., Bourdon, B., Mojzsis, S. J., Touboul, M., Sprung, P., Guitreau, M., and BlichertToft, J. (2013) Inherited ${ }^{142} \mathrm{Nd}$ anomalies in Eoarchean protoliths. Earth and Planetary Science Letters 361, 50-57.

Rudge, J. F., Kleine, T., and Bourdon, B. (2010) Broad bounds on Earth's accretion and core formation constrained by geochemical models. Nature Geoscience 3, 439-443.

Rudnick, R. L. and Gao, S. (2003) Composition of the Continental Crust. In: Holland, H. D. and Turekian, K. K. Eds.), The Crust (ed. R.L. Rudnick), Vol. 3 Treatise of Geochemistry. Elsevier-Pergamon, Oxford.

Rudnick, R.L., Barth M., Horn I., and McDonough W.F. (2000) Rutile-bearing refractory eclogites: missing link between continents and depleted mantle. Science 287, 278-281.

Saji, N. S., Larsen, K., Wielandt, D., Schiller, M., Costa, M. M., Whitehouse, M. J., Rosing, M. T., and Bizzarro, M. (2018) Hadean geodynamics inferred from time-varying ${ }^{142} \mathrm{Nd} /{ }^{144} \mathrm{Nd}$ in the early Earth rock record. Geochemical Perspectives Letters 7, 43-48.

Salacinska, A., Kusiak, M. A., Whitehouse, M. J., Dunkley, D. J., Wilde, S. A., and Kielman, R. (2018) Complexity of the early Archean Uivak Gneiss: insights from Tigigakyuk Inlet, Saglek Block, Labrador, Canada and possible correlations with Southwest Greenland. Precambrian Research 315, 103-119.

Salters, V. J. M. and Stracke, A. (2004) Composition of the depleted mantle. Geochemisty, Geophysics, Geosystems 5, doi:10.1029/2003GC000597.

Schiøtte, L., Compston, W., and Bridgewater, D. (1989) U-Th-Pb ages of single zircons in Archaean supracrustals from the Nain Province, Labrador, Canada. Canadian Journal of Earth Science 26, 2636-2644.

Schneider, K. P., Hoffmann, J. E., Boyet, M., Munker, C., and Kroner, A. (2018) Coexistence of enriched and modern-like ${ }^{142} \mathrm{Nd}$ signatures in Archean igneous rocks of the eastern Kaapvaal Craton, southern Africa. Earth and Planetary Science Letters 487, 54-66.

Schoene, B., Dudas, F. O. L., Bowring, S. A., and deWit, M. (2009) Sm-Nd isotopic mapping of lithospheric growth and stabilization in the eastern Kaapvaal craton. Terra Nova 21, 219228. 
Shearer, C. K. and Righter, K. (2003) Behavior of tungsten and hafnium in silicates: A crystal chemical basis for understanding the early evolution of the terrestrial planets. Geophysical Research Letters 30, doi:10.1029/2002GL015523.

Shimojo, M., Yamamoto, S., Sakata, S., Yokoyama, T. D., Maki, K., Sawaki, Y., Ishikawa, A., Aoki, K., Koshida, K., Tashiro, T., Hirata, T., Collerson, K. D., and Komiya, T. (2016) Occurrence and geochronology of the Eoarchean, 3.9 Ga, Iqaluk Gneiss in the Saglek Block, northern Labrador, Canada: Evidence for the oldest supracrustal rocks in the world. Precambrian Research 278, 218-243.

Shirey, S. B. and Richardson, S. H. (2011) Start of the Wilson cycle at 3 Ga shown by diamonds from subcontinental mantle. Science 333, 434-436.

Sircombe, K. N., Bleeker, W., and Stern, R. A. (2001) Detrital zircon geochronology and grainsize analysis of an approximately 2800 Ma Mesoarchean proto-cratonic cover succession, Slave Province, Canada. Earth and Planetary Science Letters 189, 207-220.

Soderlund, U., Patchett, P. J., Vervoort, J. D., and Isachen, C. E. (2004) The ${ }^{176}$ Lu decay constant determined by Lu-Hf and U-Pb isotope systematics of Precambrian mafic intrusions. Earth and Planetary Science Letters 219, 311-324.

Solomatov, V. S. and Moresi, L.-N. (1996) Stagnant lid convection on Venus. Journal of Geophysical Research Planets

Sprung, P., Kleine, T., and Scherer, E. E. (2013) Isotopic evidence for chondritic Lu/Hf and Sm/Nd of the Moon. Earth and Planetary Science Letters 380, 77-87.

St. Onge, M. R., King, J. E., and Lalonde, A. E. (1988) Geology, east-central Wopmay Orogen, District of Mackenzie, Northwest Territories. Geological Survey of Canada, Open File Report 1923,

Stern, R. J. (2005) Evidence from ophiolites, blueschists, and ultrahigh-pressure metamorphic terranes that the modern episode of subduction tectonics began in Neoproterozoic time. Geology 33, 557-560.

Tanaka, T., Togashi, S., Kamioka, H., Amakawa, H., Kagami, H., Hamamoto, T., Yuhara, M., Orihashi, Y., Yoneda, S., Shimizu, H., Kunimaru, T., and Takahashi, K. (2000) JNdi: a neodymium isotopic reference in consistency with La Jolla neodymium. Chemical Geology 168, 279-281.

Tang, M., Chen, K., and Rudnick, R. L. (2016) Archean upper crust transition from mafic to felsic marks the onset of plate tectonics. Science 351, 372-375.

Tera, F., Papanastassiou, D. A., and Wasserburg, G. J. (1974) Isotopic evidence for a terminal lunar cataclysm. Earth and Planetary Science Letters 22, 1-21.

Thorpe, R. I., Cumming, G. L., and Mortensen, J. K. (1992) A significant Pb isotope boundary in the Slave Province and its probable relation to ancient basement in the western Slave Province. Geological Survey of Canada, Open File Report 2484, 179-184.

Touboul, M., Kleine, T., Bourdon, B., Palme, H., and Wieler, R. (2007) Late formation and prolonged differentiation of the Moon inferred from $\mathrm{W}$ isotopes in lunar metals. Nature 450, 1206-1209.

Touboul, M., Liu, J., O'Neil, J., Puchtel, I. S., and Walker, R. J. (2014) New insights into the Hadean mantle revealed by ${ }^{182} \mathrm{~W}$ and highly siderophile element abundances in supracrustal rocks from the Nuvvuagittuq greenstone belt, Quebec, Canada. Chemical Geology 383, 63-75. 
Touboul, M., Puchtel, I. S., and Walker, R. J. (2012) ${ }^{182}$ W evidence for long-term preservation of early mantle differentiation products. Science 335, 1065-1069.

Touboul, M., Puchtel, I. S., and Walker, R. J. (2015) Tungsten isotopic evidence for disproportional late accretion to the Earth and Moon. Nature 520, 530-533.

Turner, S., Rushmer, T., Reagan, M., and Moyen, J.-F. (2014) Heading down early on? Start of subduction on Earth. Geology 42, 139-142.

Valley, J. W., Cavosie, A. J., Ushikubo, T., Reinhard, D. A., Lawrence, D. F., Larson, D. J., Clifton, P. H., Kelly, T. F., Wilde, S. A., Moser, D. E., and Spicuzza, M. J. (2014) Hadean age for a post-magma-ocean zircon confirmed by atom-probe tomography. Nature Geoscience 7, 219-223.

Valley, J. W., Peck, W. H., King, E. M., and Wilde, S. A. (2002) A cool early Earth. Geology 30, 351-354.

van Breemen, O., Davis, W. J., and King, J. E. (1992) Temporal distribution of granitoid plutonic rocks in the Archean Slave Province, northwest Canadian Shield. Canadian Journal of Earth Science 22, 2186-2199.

Van Hunen, J. and Moyen, J.-F. (2012) Archean subduction: fact or fiction. Annual Review of Earth and Planetary Sciences 40, 195-219.

Van Kranendonk, M. J., Smithies, R. H., Hickman, A. H., Wingate, M. T. D., and Bodorkos, S. (2010) Evidence for Mesoarchean (similar to 3.2 Ga) rifting of the Pilbara Craton: The missing link in an early Precambrian Wilson cycle. Precambrian Research 177, 145-161.

Vervoort, J. D. and Blichert-Toft, J. (1999) Evolution of the depleted mantle: $\mathrm{Hf}$ isotope evidence from juvenile rocks through time. Geochimica et Cosmochimica Acta 63, 533-556.

Vervoort, J. D. and Kemp, A. I. S. (2016) Clarifying the zircon Hf isotope record of crust-mantle evolution. Chemical Geology 425, 65-75.

Vervoort, J. D., Patchett, P. J., Gehrels, G. E., and Nutman, A. P. (1996) Constraints on Earth differentiation from hafnium and neodymium isotopes. Nature 379, 624-627.

Vervoort, J. D., Plank, T., and Prytulak, J. (2011) The Hf-Nd isotopic composition of marine sediments. Geochimica et Cosmochimica Acta 75, 5903-5926.

Vezinet, A., Pearson, D. G., Thomassot, E., R.A.Stern, Sarkar, C., Luo, Y., and Fisher, C. M. (2018) Hydrothermally-altered mafic crust as source for early TTG: $\mathrm{Pb} / \mathrm{Hf} / \mathrm{O}$ isotope and trace element evidence in zircon from TTG of the Eoarchean Saglek Block, N. Labrador. Earth and Planetary Science Letters 503, 95-107.

Vockenhuber, C., Oberli, F., Bichler, M., Ahmad, I., Quitte, G., Meier, M., Halliday, A. N., Lee, D.C., Kutschera, W., Steier, P., Gehrke, R. J., and Helmer, R. G. (2004) New half-life measurement of ${ }^{182} \mathrm{Hf}$ : improved chronometer for the early Solar System. Physical Review Letters 93, 172501.

Walker, R. J. (2009) Highly siderophile elements in the Earth, Moon and Mars: Update and implications for planetary accretion and differentiation. Chemie der Erde 69, 101-125.

Warren, P. H. and Wasson, J. T. (1979) The origin of KREEP. Reviews of Geophysics and Space Physics 17, 73-88.

Wasilewski, B., O'Neil, J., and Rizo, H. (2019) Geochemistry and petrogenesis of the early Archean mafic crust from the Saglek-Hebron Complex (Northern Labrador). Precambrian Research 328, 
Wasilewski, B., O’Neil, J., Rizo, H., Paquette, J. L., and Boyet, M. (2018) From early juvenile source to late crustal reworking: the evolution of the Saglek-Hebron crust. EGU General Assembly Conference Abstracts 20, 10284.

Waterton, P., Pearson, D. G., Kjarsgaard, B., Hulbert, L., Locock, A., Parman, S., and Davis, B. (2017) Age, origin, and thermal evolution of the ultra-fresh $1.9 \mathrm{Ga}$ Winnipegosis komatiites, Manitoba, Canada. Lithos 268, 114-130.

Watson, E. B. and Harrison, T. M. (2005) Zircon thermometer reveals minimum melting conditions on earliest Earth. Science 308, 841-844.

Wetherill, G. W. (1990) Formation of the Earth. Annual Review of Earth and Planetary Sciences $18,205-256$.

Whitehouse, M. J., Dunkley, D. J., Kusiak, M. A., and Wilde, S. A. (2019) On the true antiquity of Eoarchean chemofossils-assessing the claim for Earth's oldest biogenic graphite in the Saglek Block of Labrador. Precambrian Research 323, 70-81.

Willbold, M., Elliott, T., and Moorbath, S. (2011) The tungsten isotopic composition of the Earth's mantle before the terminal bombardment. Nature 477, 195-198.

Willbold, M., Mojzsis, S. J., Chen, H.-W., and Elliott, T. (2015) Tungsten isotope composition of the Acasta Gneiss Complex. Earth and Planetary Science Letters 419, 168-177.

Wohlers, A. and Wood, B. J. (2017) Uranium, thorium and REE partitioning into sulfide liquids: implications for reduced S-rich bodies. Geochimica et Cosmochimica Acta 205, 226-244.

Wood, J.A., Dickey, J.S., Marvin, U.B., and Powell, B.N. (1970) Lunar anorthosites and a geophysical model of the Moon. Proceedings of the Apollo 11 Lunar Science Conference, 965-988.

Workman, R. K. and Hart, S. R. (2005) Major and trace element composition of the depleted MORB mantle (DMM). Earth and Planetary Science Letters 231, 53-72.

Xing, G.-F., Wang, X.-L., Wan, Y., Chen, Z.-H., Jiang, Y., Kitajima, K., Ushikubo, T., and Gopon, P. (2014) Diversity in early crustal evolution: 4100 Ma zircons in the Cathaysia Block of southern China. Scientific Reports

Yin, Q., Jacobsen, S. B., Yamashita, K., Blichert-Toft, J., Telouk, P., and Albarede, F. (2002) A short timescale for terrestrial planet formation from $\mathrm{Hf}-\mathrm{W}$ chronometry of meteorites. Nature 418, 949-952.

Zellner, N. E. B. (2017) Cataclysm no more: new views on the timing and delivery of lunar impactors. Origins of Life and Evolution of Biospheres 47, 261-280. 

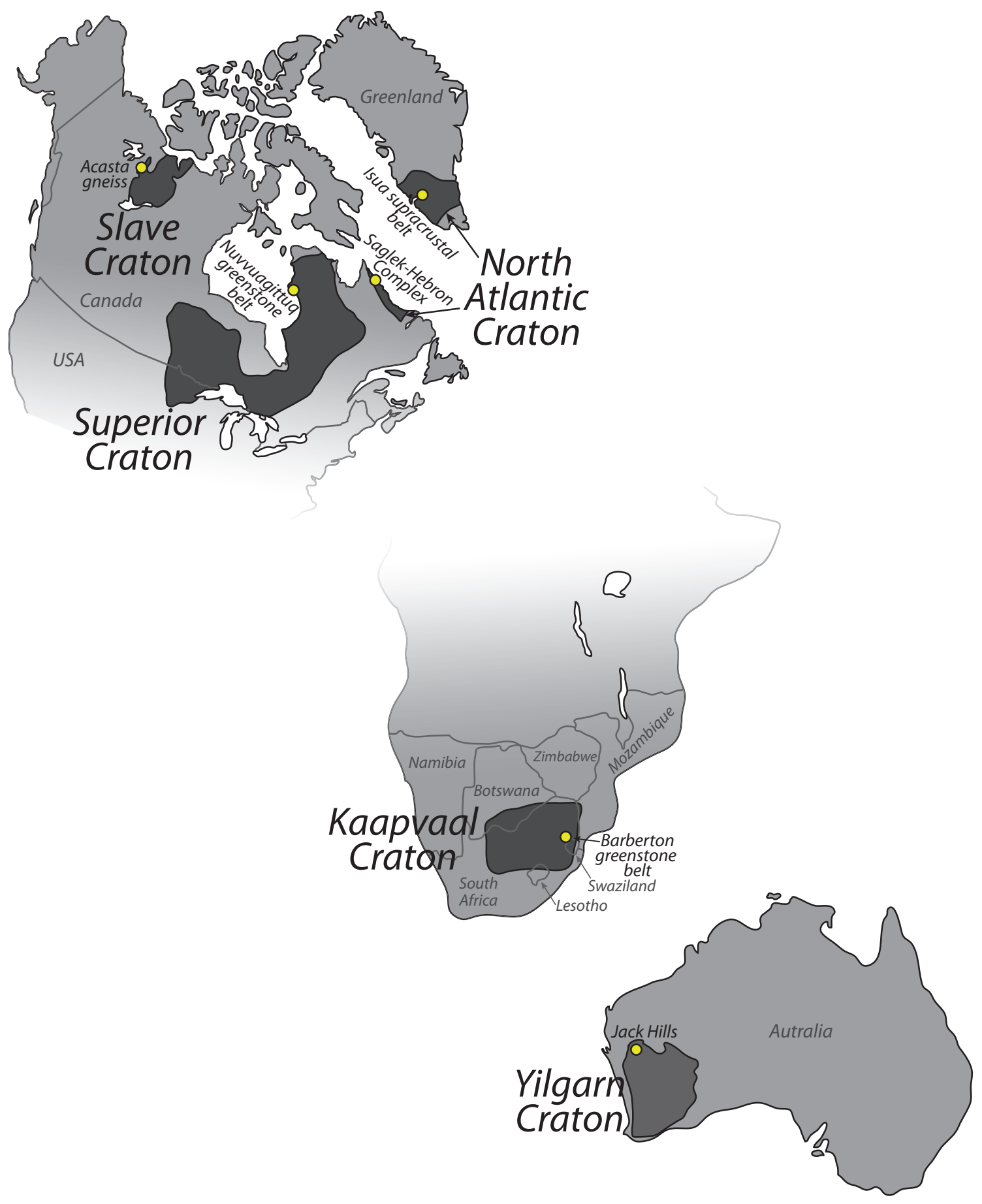

Figure 1: Location map of the Hadean/Archean terranes discussed extensively in this paper. 


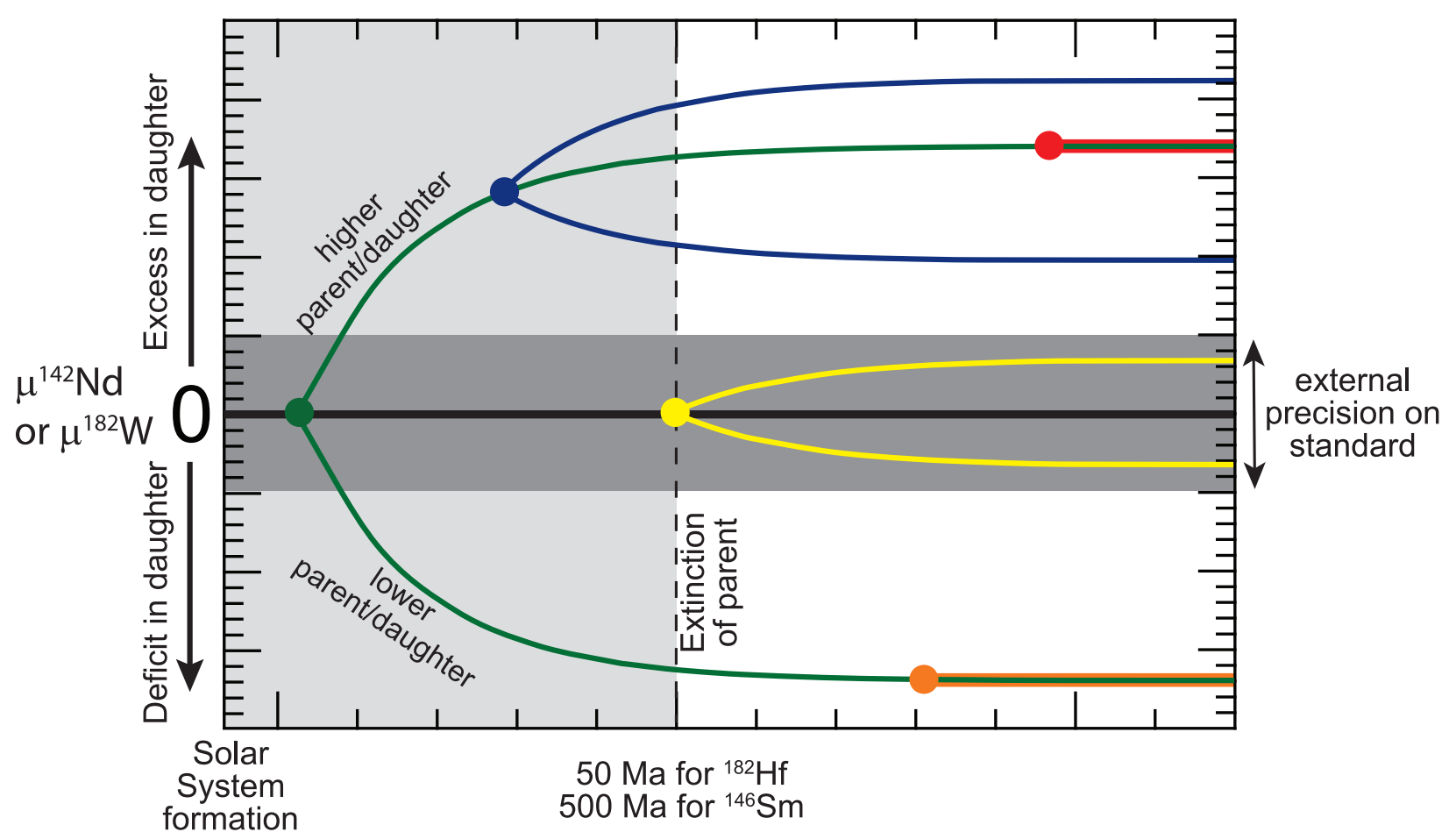

Figure 2: Schematic evolution of the daughter isotopic composition of the short-lived ${ }^{146} \mathrm{Sm}$ ${ }^{142} \mathrm{Nd}$ and ${ }^{182} \mathrm{Hf}-{ }^{182} \mathrm{~W}$ systems. Differentiation events (blue and green circles) that change the parent/daughter elemental ratio while the parent is still extant result in a change in daughter isotope composition that reflects the time of the event and the magnitude of parent/daughter fractionation. Differentiation events (yellow, red, and orange circles) that occur after the extinction of the parent will not lead to a measurable change in daughter isotope composition, so the products of these later events inherit the record of earlier differentiation events in their sources. 

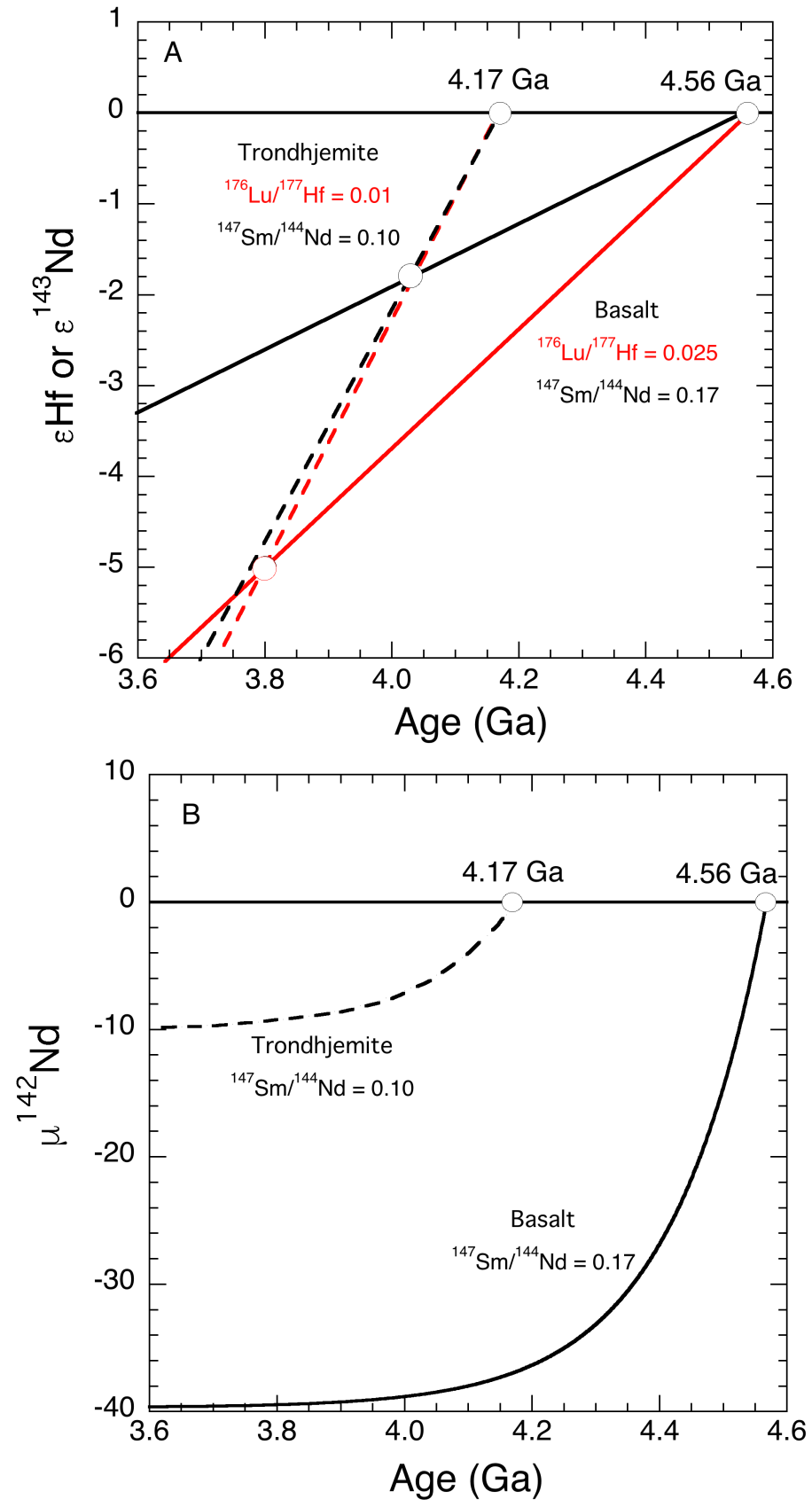

Figure 3: Hypothetical $\varepsilon \mathrm{Hf}, \varepsilon^{143} \mathrm{Nd}$ and $\mu^{142} \mathrm{Nd}$ evolution curves that could produce an initial $\varepsilon \mathrm{Hf}$ $=-5$ for a rock at $3.8 \mathrm{Ga}$. The models assume a simple three-stage evolution where stage 1 is a mantle source evolving with chondritic $\mathrm{Lu} / \mathrm{Hf}$ and $\mathrm{Sm} / \mathrm{Nd}$, stage 2 involves either an evolved protolith (dashed lines $-{ }^{176} \mathrm{Lu} /{ }^{177} \mathrm{Hf}=0.01 ;{ }^{147} \mathrm{Sm} /{ }^{144} \mathrm{Nd}=0.10$ ) typical of an Archean TTG, or a less evolved composition (solid lines $-{ }^{176} \mathrm{Lu} /{ }^{177} \mathrm{Hf}=0.025 ;{ }^{147} \mathrm{Sm} /{ }^{144} \mathrm{Nd}=0.17$ ) typical of a basalt. In part A, the red evolution lines are for $\mathrm{Lu}-\mathrm{Hf}$ while the black are for ${ }^{147} \mathrm{Sm}-{ }^{143} \mathrm{Nd}$. The figures illustrate how the combination of initial $\mathrm{Hf}$ isotopic measurements coupled with ${ }^{142} \mathrm{Nd} /{ }^{144} \mathrm{Nd}$ data can be used to better define the composition and age of the protolith of an ancient crustal rock. 


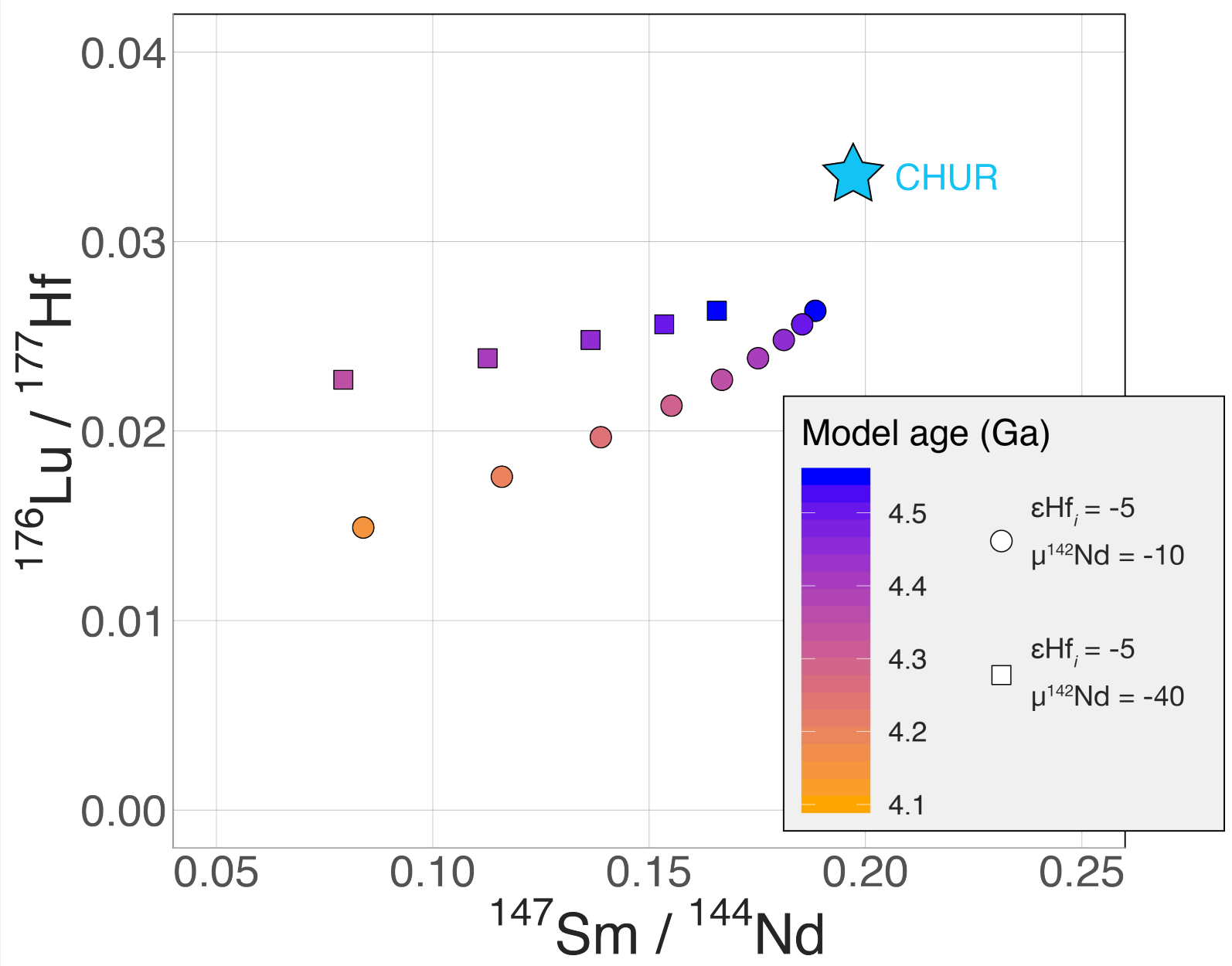

Figure 4: Source Lu/Hf and Sm/Nd ratios calculated for the two hypothetical samples in Figure 3. Each point shows the combination of parent/daughter ratios and differentiation age that would produce the measured isotopic composition of the sample at $3.8 \mathrm{Ga}$. The squares are for the sample with $\varepsilon \mathrm{Hf}=-5$ and $\mu^{142} \mathrm{Nd}=-40$ while the circles provide the family of solutions for $\varepsilon \mathrm{Hf}=-5$ and $\mu^{142} \mathrm{Nd}=-10$. 

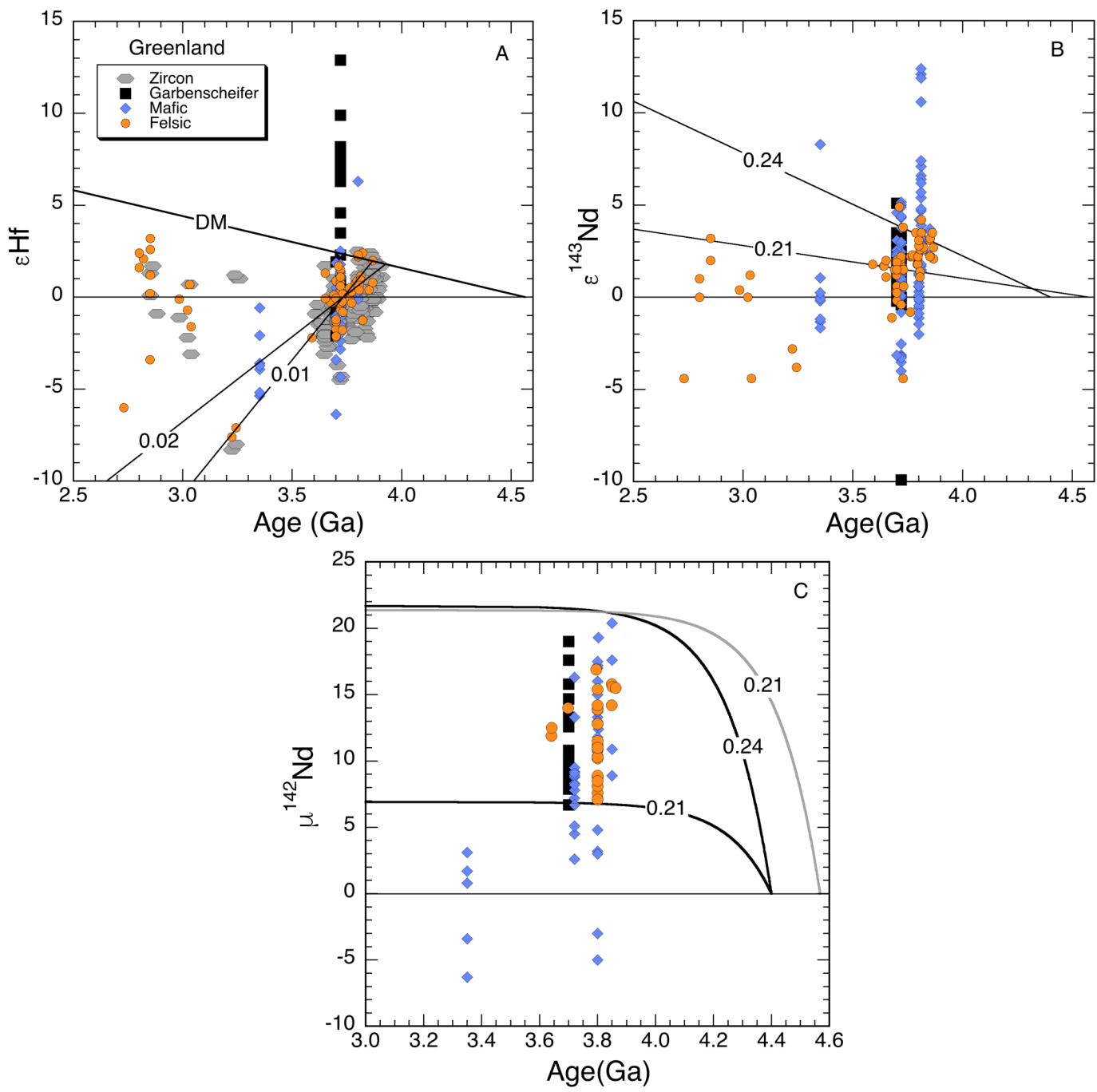

Figure 5: Initial $\mathrm{Hf}$ and $\mathrm{Nd}$ isotopic composition of early Archean rocks from southern Greenland. A) Zircon data from (Hiess et al., 2009; Kemp et al., 2009; Amelin et al., 2011; Naeraa et al., 2012; Fisher and Vervoort, 2018; Kemp et al., 2019) and whole rock data from (Blichert-Toft et al., 1999; Vervoort and Blichert-Toft, 1999; Hoffmann et al., 2010, 2011a,b, 2014; Rizo et al., 2011, 2013). When necessary, the $\varepsilon H f$ data were recalculated to the chondrite Lu-Hf reference parameters of Bouvier et al. (2008) using the ${ }^{176} \mathrm{Lu}$ half-life of Soderlund et al. (2004). The depleted mantle (DM) evolution line is the connector between $\varepsilon \mathrm{Hf}=0$ at $4.56 \mathrm{Ga}$ and a present day average MORB value of 13. The thin lines on the figure show the slopes for isotopic evolution with ${ }^{176} \mathrm{Lu} /{ }^{177} \mathrm{Hf}$ ratios of 0.01 (a typical value for a HREE depleted trondhjemite) and 0.02 (a typical basaltic value) adjusted to pass through the middle of the data cloud at $3.8 \mathrm{Ga}$. B) Nd data from (Blichert-Toft et al., 1999; Vervoort and Blichert-Toft, 1999; Frei and Jensen, 2003; Frei et al., 2004; Caro et al., 2006; Bennett et al., 2007; Hoffmann et al., 2010, 2011; Rizo et al., 2011, 2012, 2013; O'Neil et al., 2016; Saji et al., 2018). The evolution lines are calculated relative to the chondritic Sm-Nd parameters of Bouvier et al. (2008). The lines track the evolution of a source with ${ }^{147} \mathrm{Sm} /{ }^{144} \mathrm{Nd}=$ 0.21 formed at $4.56 \mathrm{Ga}$ that would evolve to the present day average $\varepsilon^{143} \mathrm{Nd}$ of MORB (+8) (Gale et al., 2013). The evolution line with ${ }^{147} \mathrm{Sm} /{ }^{144} \mathrm{Nd}=0.24$ starts from a chondritic $\mathrm{Nd}$ isotopic composition at $4.4 \mathrm{Ga}$ with the $\mathrm{Sm} / \mathrm{Nd}$ chosen to reach the highest values recorded for the Eoarchean rocks from Greenland. If continued to the present day, this source would today have an $\varepsilon^{143} \mathrm{Nd}=+25$. C) $\mu^{142} \mathrm{Nd}$ relative to a terrestrial reservoir evolving with ${ }^{147} \mathrm{Sm} /{ }^{144} \mathrm{Nd}=0.196$ (Bouvier et al., 2008) and a present day ${ }^{142} \mathrm{Nd} /{ }^{144} \mathrm{Nd}$ equal to the value measured in the different laboratories for the JNdi Nd standard. The evolution curves are for present day ${ }^{147} \mathrm{Sm} /{ }^{144} \mathrm{Nd}$ ratios of 0.21 and 0.24 starting from $\mu^{142} \mathrm{Nd}=0$ at either $4.4 \mathrm{Ga}$ or $4.56 \mathrm{Ga}$. 


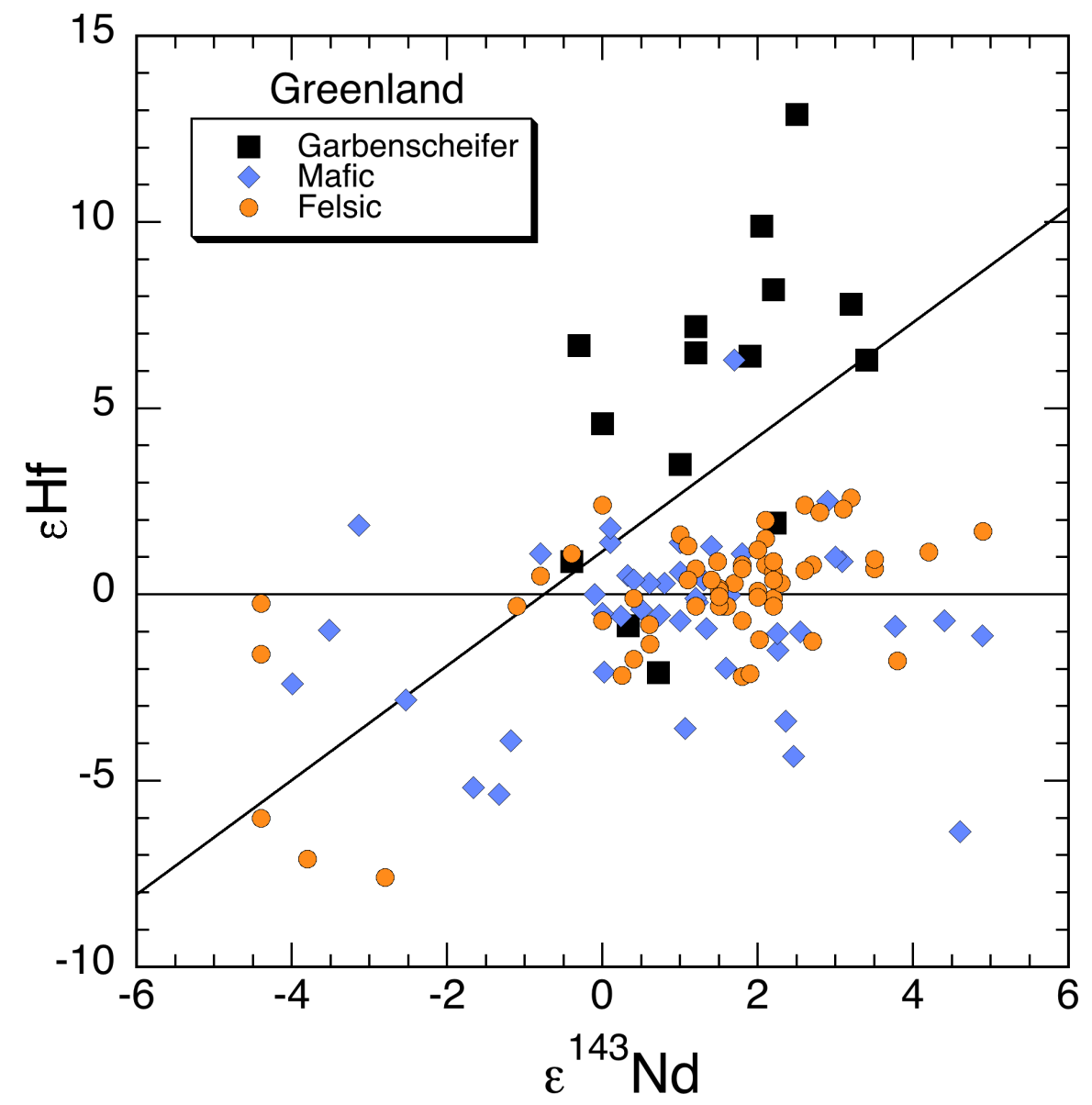

Figure 6: Initial $\mathrm{Nd}$ versus $\mathrm{Hf}$ isotopic composition in the Eoarchean rocks from Greenland. The sloped line in the figure is the Nd-Hf correlation line from Vervoort et al. (2011). Data from the same sources as in figure 5 . 

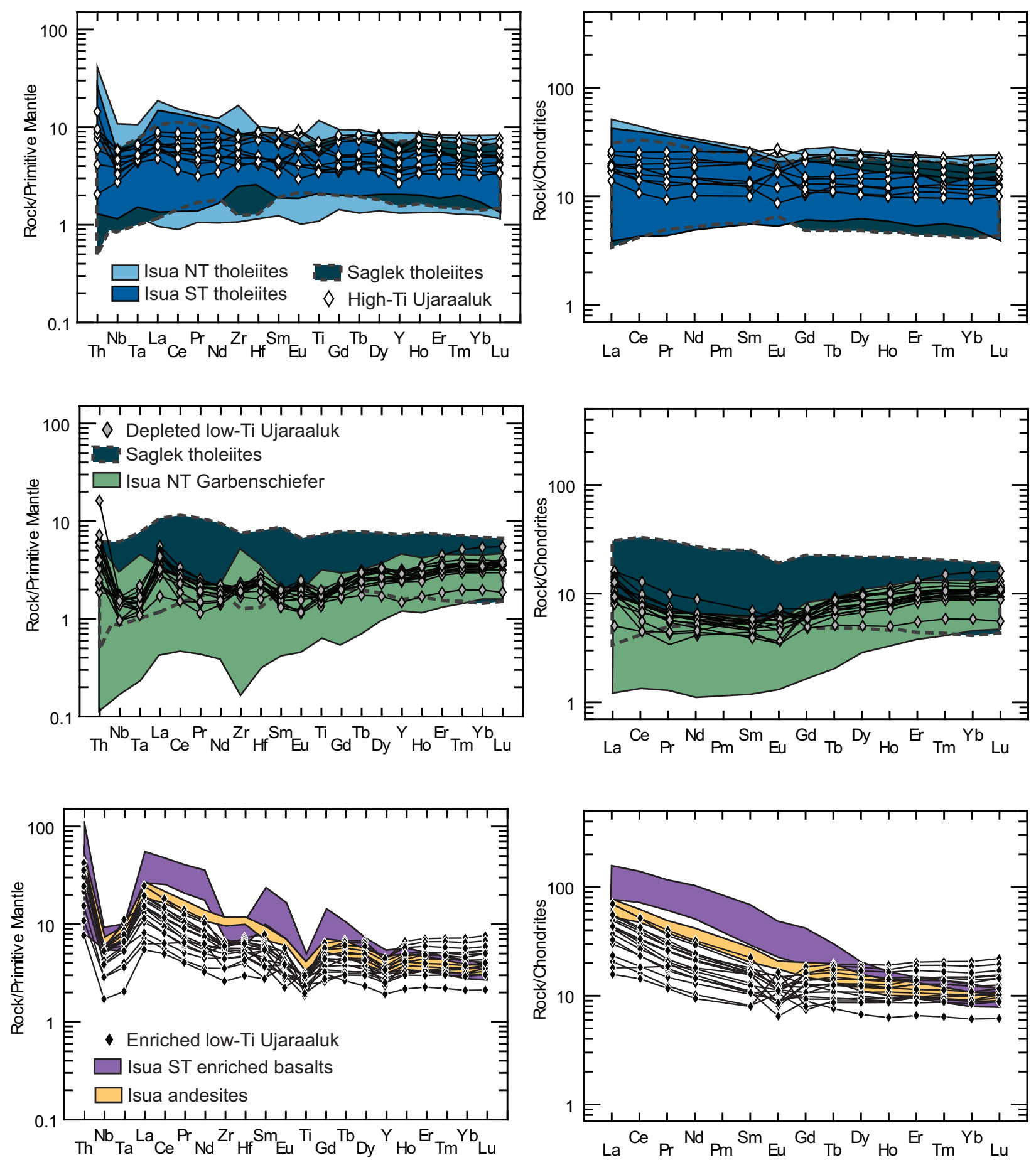

Figure 7: Primitive mantle normalized trace element and rare-earth-element patterns for the three compositional groups of the Ujaraaluk unit of the Nuvvuagittuq supracrustal belt in comparison to similar rock types from Isua and Saglek. NT and ST for the Isua data denote samples from the Northern or Southern Terrane. Figure modified from that of O'Neil et al. (2016) with the addition of Saglek data from Wasilewski et al. (2018). 


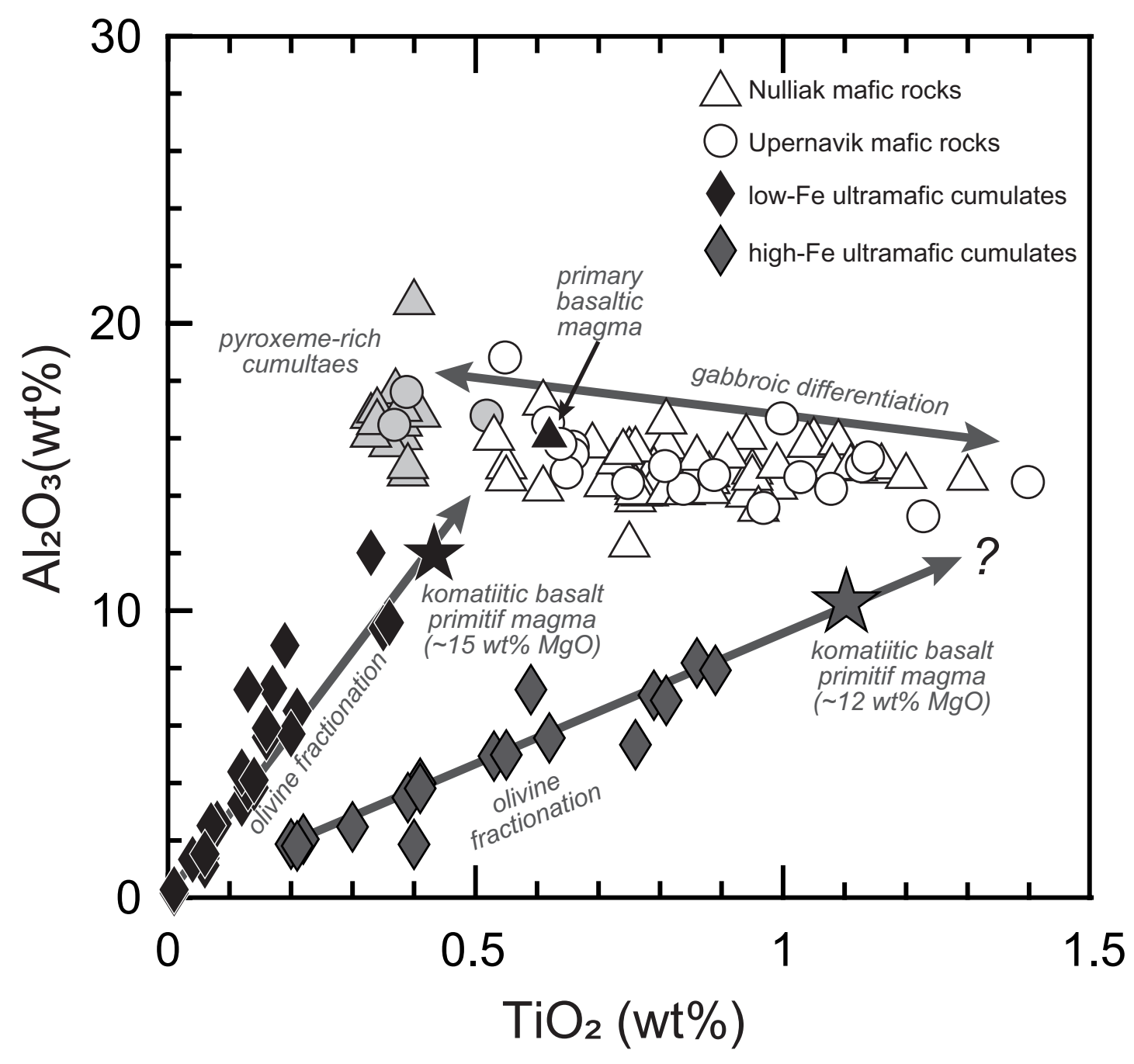

Figure 8: $\mathrm{Al}_{2} \mathrm{O}_{3}$ versus $\mathrm{TiO}_{2}$ concentrations showing the role of olivine and pyroxene accumulation in driving the compositional evolution of the SHC mafic parental magmas. Data from Wasilewski et al. (2018). 

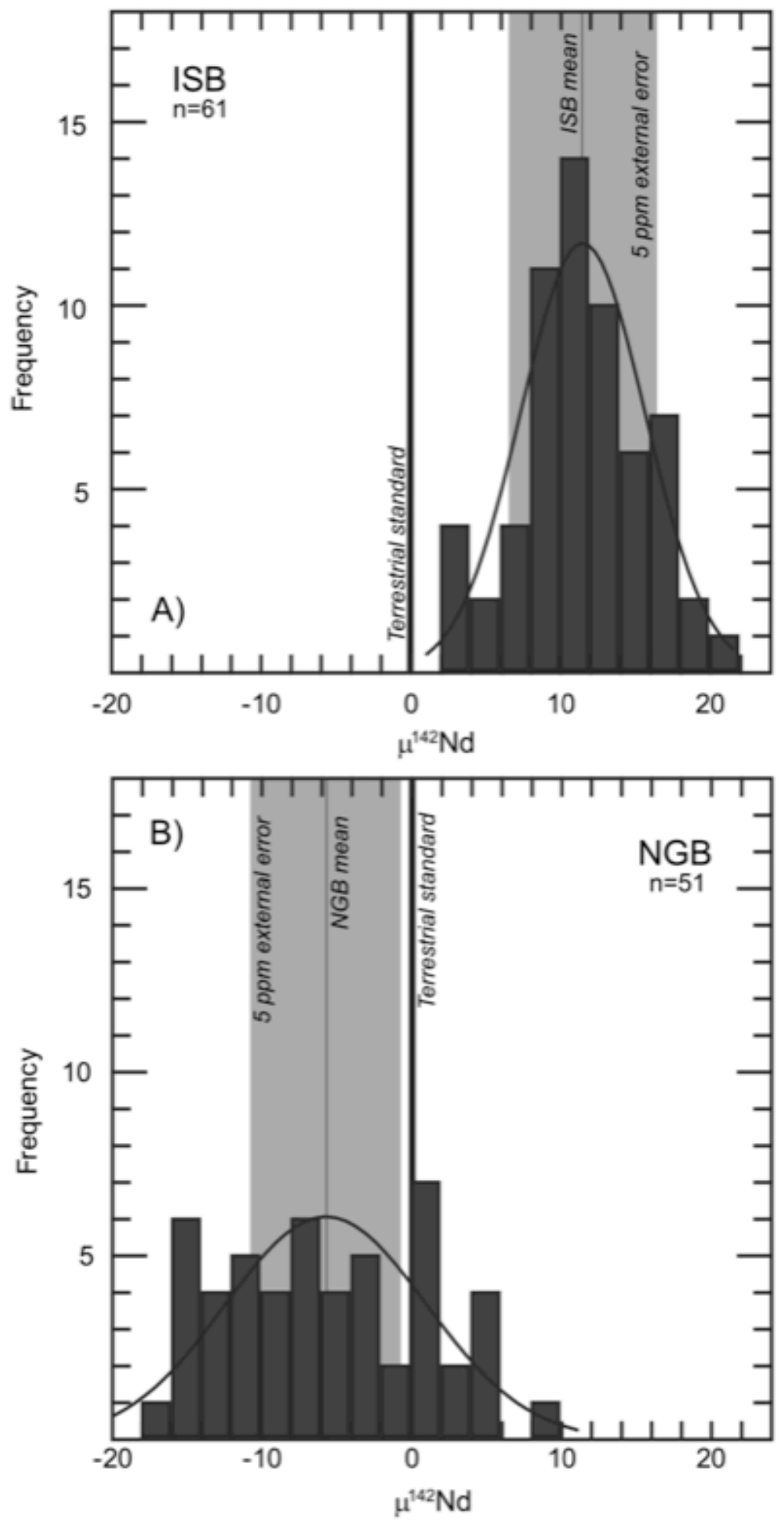

Figure 9: Histogram of $\mu^{142} \mathrm{Nd}$ values measured in supracrustal rocks from Isua Supracrustal Belt (ISB) and Nuvvuagittuq Greenstone Belt (NGB). Figure from O'Neil et al. (2016). 

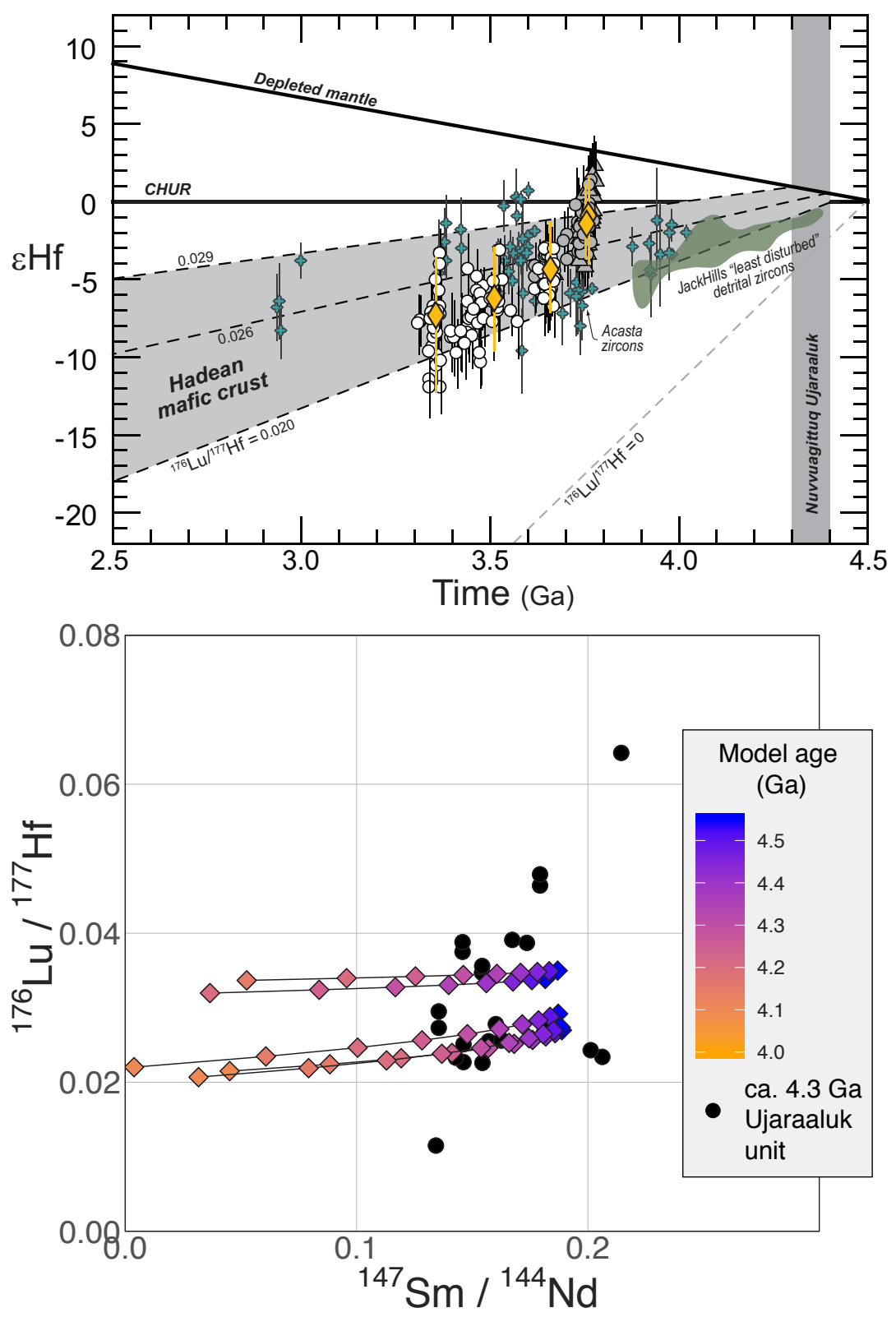

Figure 10: Part A shows the evolving $\mathrm{Hf}$ isotopic composition of zircons measured in the Nuvvuagittuq TTG in comparison to fields for zircon data from Acasta and the Jack Hills. The yellow diamonds show the average composition for zircons from a single sample. The grey region shows the expected $\mathrm{Hf}$ isotope evolution for mafic basement with $\mathrm{Lu} / \mathrm{Hf}$ ratios similar to those measured for the Ujaraaluk samples. Figure after O'Neil et al. (2013). Part B shows the model $\mathrm{Sm} / \mathrm{Nd}$ and $\mathrm{Lu} / \mathrm{Hf}$ ratios calculated for five felsic rocks from the Nuvvuagittuq region that will allow these two systems to provide concordant depleted mantle model ages that are color coded by age by the legend on the right. The modeled parent/daughter ratios overlap well with measured $\mathrm{Lu} / \mathrm{Hf}, \mathrm{Sm} / \mathrm{Nd}$ of the Ujaraaluk unit (black circles), if the Ujaraaluk unit is indeed ca $4.3 \mathrm{Ga}$ in age. Note that some of the scatter in $\mathrm{Sm} / \mathrm{Nd}$ and Lu/Hf may be due to postemplacement processes, most notably garnet formation. 


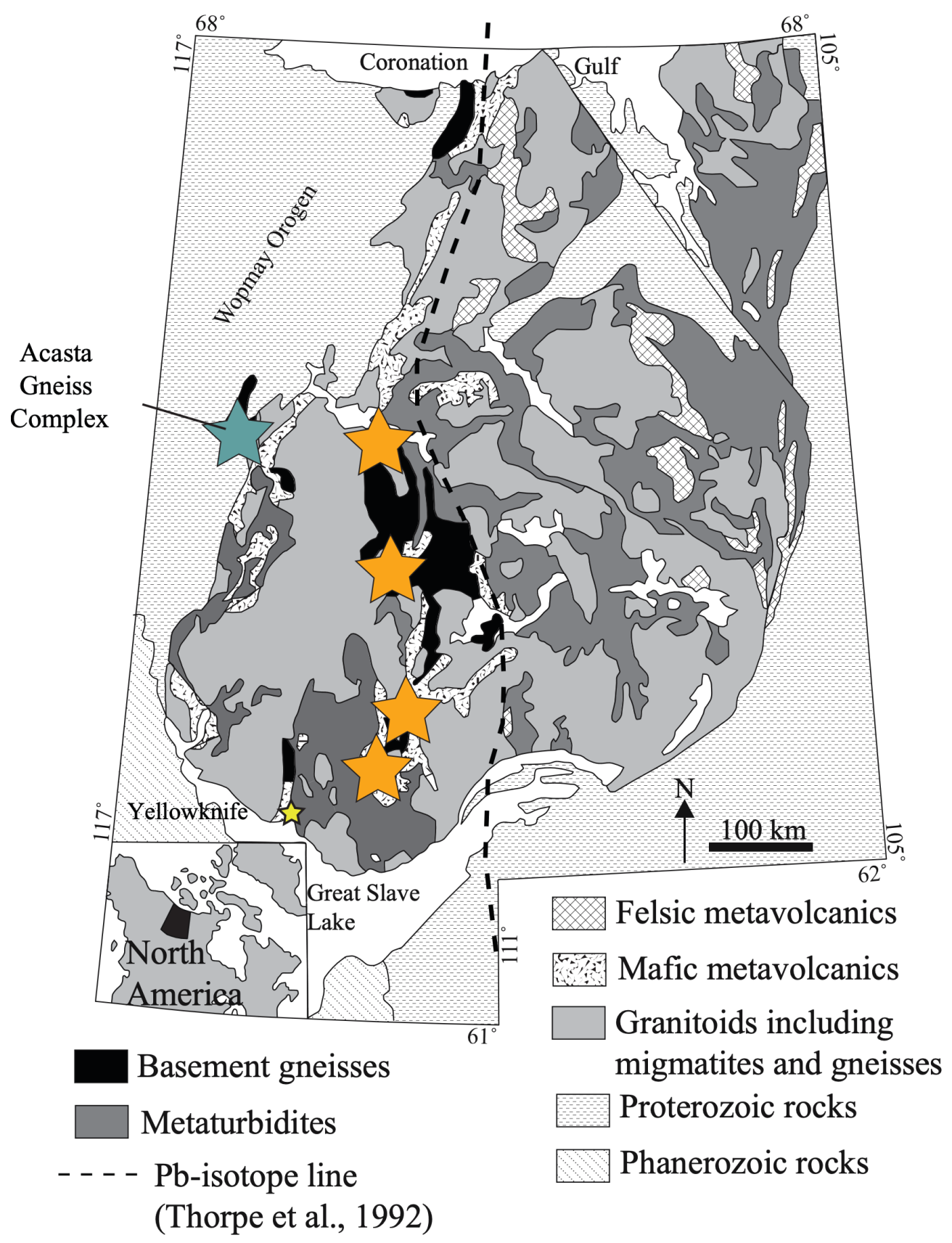

Figure 11: Geologic map of the Slave craton modified from St. Onge et al. (1988), Bleeker and Davis (1999), and Bleeker et al. (1999). The map shows the major basement complexes as well as crustal province boundaries inferred from $\mathrm{Pb}$ (Thorpe et al., 1992) and $\mathrm{Nd}$ (Davis and Hegner, 1992) isotopic data. The dotted line represents the extent of the Central Slave Basement Complex, as defined by Bleeker et al. (1999), which does not include the Acasta Gneiss Complex. 


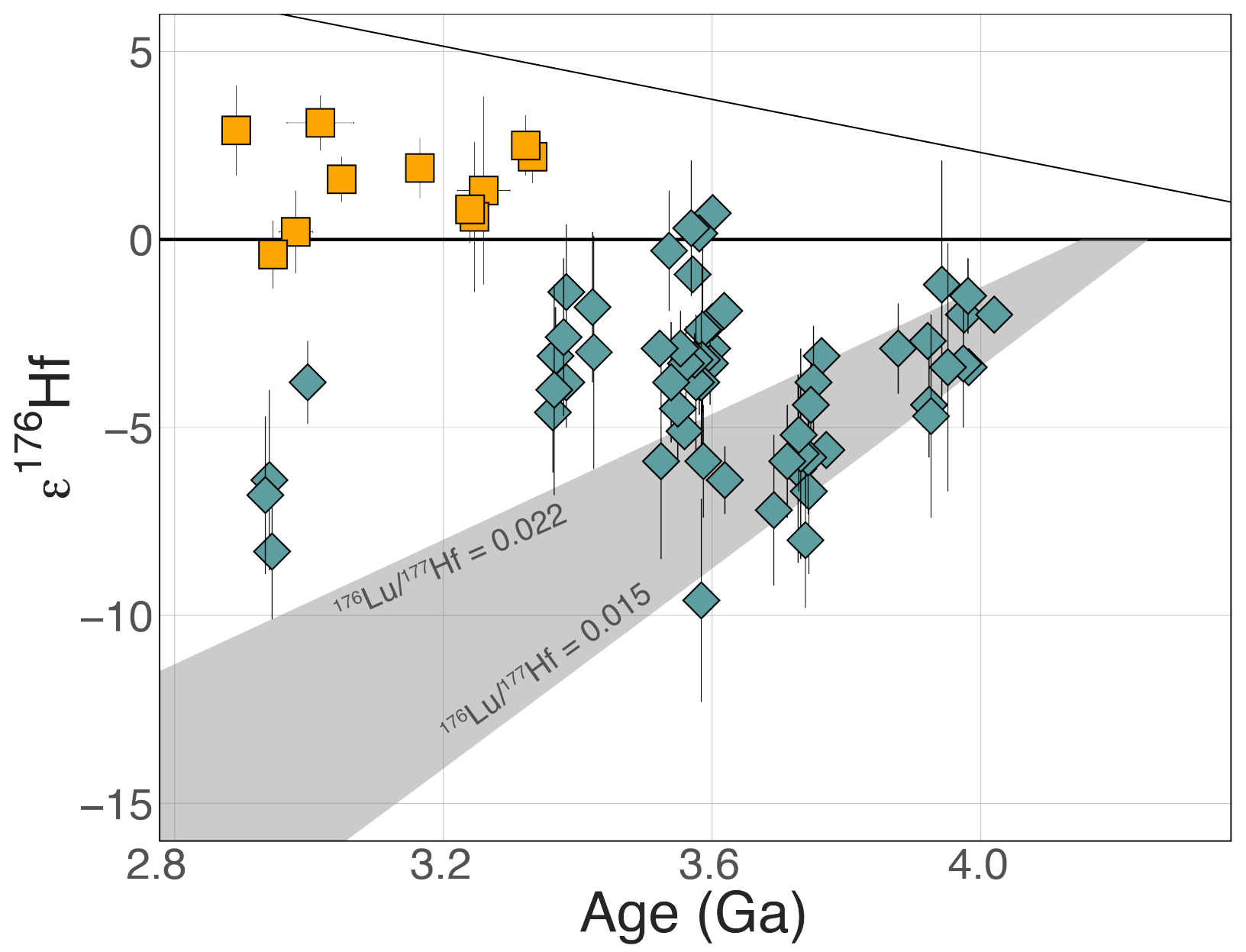

Figure 12: Initial $\varepsilon \mathrm{Hf}$ for zircons from Slave igneous rocks. Data from Acasta from Amelin et al. (1999, 2000), lizuka et al. (2009), Guitreau et al. (2014), Reimink et al. (2016a), Bauer et al. (2017), Reimink et al. (2019). The Central Slave data are from Reimink et al. (2019). The color code for the points corresponds to the localities shown by the colored stars in figure 11 . The thin sloped line shows a model for the evolution of $\varepsilon \mathrm{Hf}$ in the depleted mantle. 


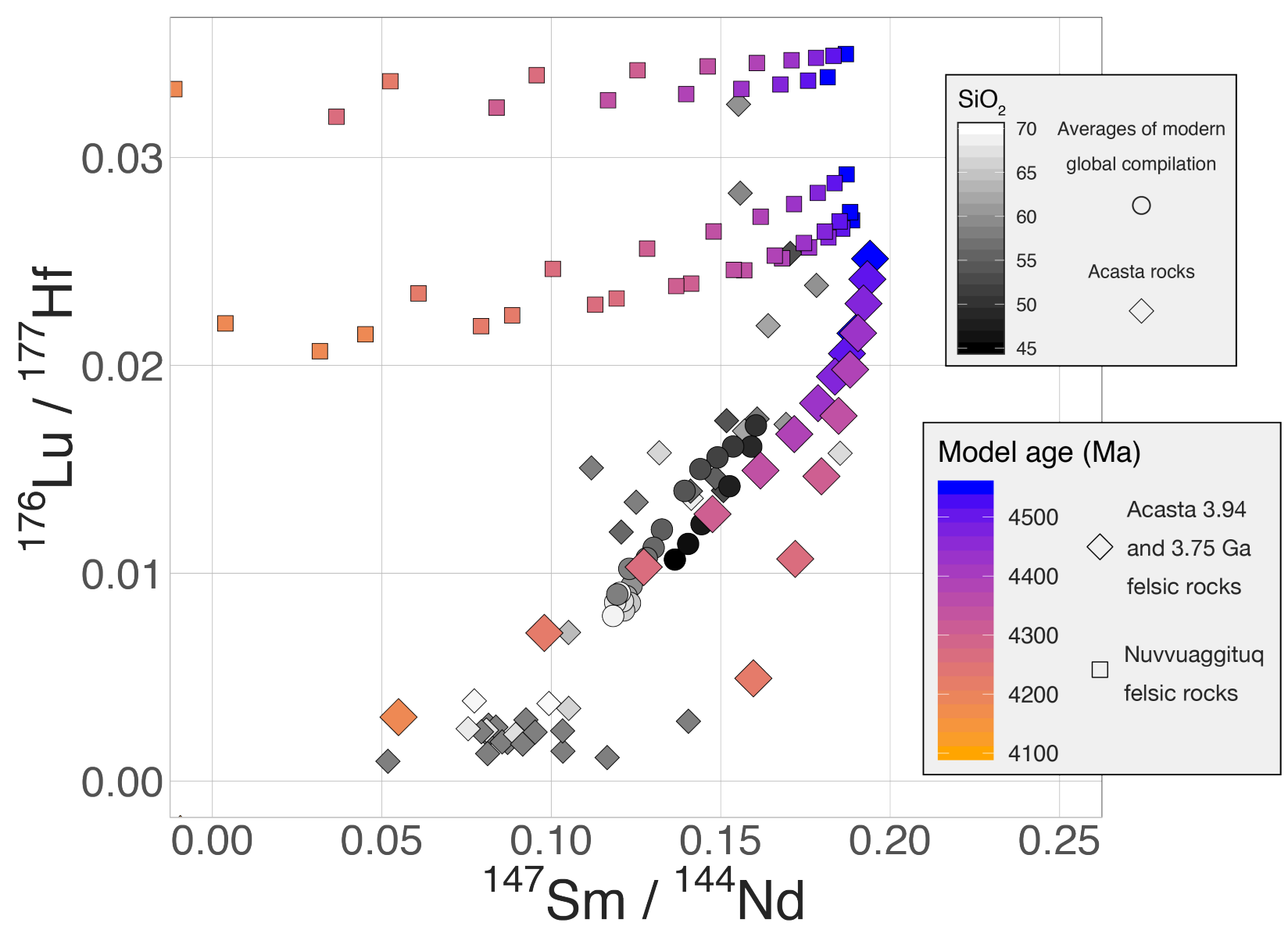

Figure 13: Model source $\mathrm{Lu} / \mathrm{Hf}$ and $\mathrm{Sm} / \mathrm{Nd}$ ratios for Acasta felsic rocks, compared with those plotted in figure 10 from Nuvvuagittuq. The geometric means for $\mathrm{Lu} / \mathrm{Hf}$ and $\mathrm{Sm} / \mathrm{Nd}$ of modern rocks pulled from the GeoRoc database, and binned by $\mathrm{SiO}_{2}$ are shown by the grey-scale circles. Note that rocks with $\mathrm{SiO}_{2}>70 \mathrm{wt} \%$ have been excluded as these compositions cannot be sources to the tonalites evaluated here due to major element differences (c.f. Boehnke et al., 2018). 


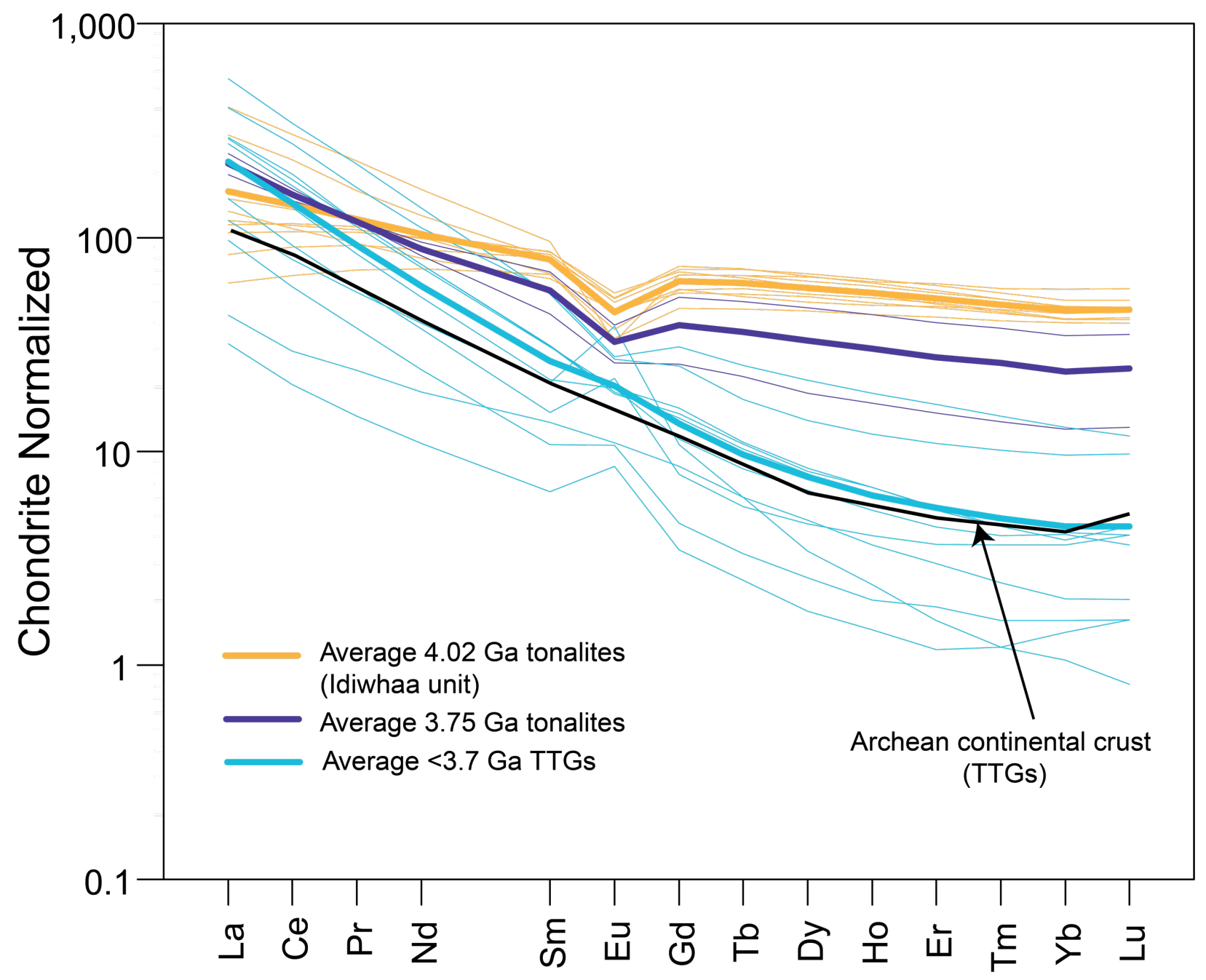

Figure 14: Evolution of REE patterns with time for the felsic rocks of the Acasta region. Data for Acasta rocks from Reimink et al. (2016a) and for representative Archean TTG from Moyen and Martin (2012). 


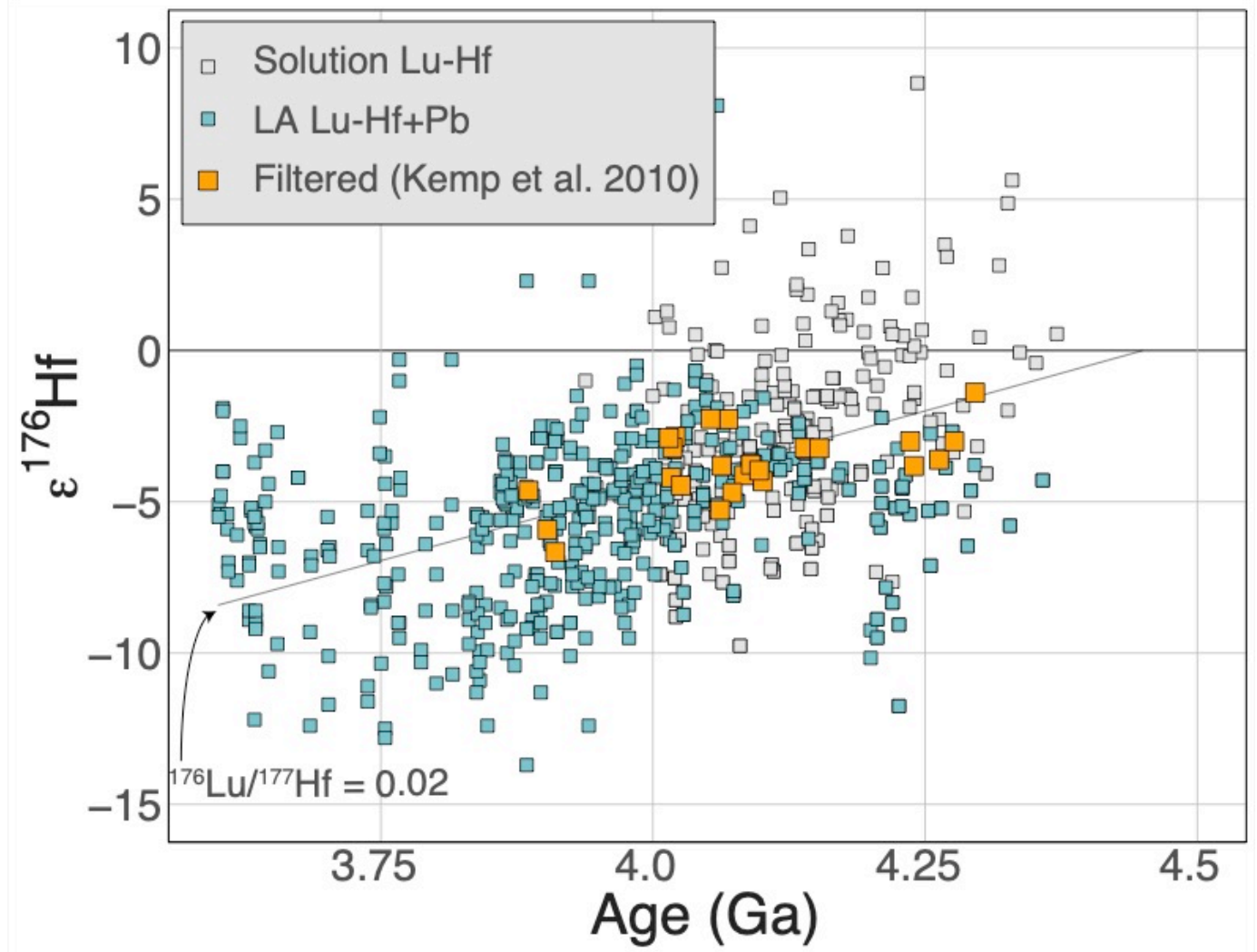

Figure 15: Data for initial $\varepsilon \mathrm{Hf}$ determined for Jack Hills zircons by combination of ion-probe U$\mathrm{Pb}$ and solution Lu-Hf (grey squares: Harrison et al. $(2005,2008)$, Blichert-Toft and Albarède (2008)) or combined $\mathrm{Pb}( \pm \mathrm{U})$, Lu-Hf determinations by laser ablation ICP-MS (blue squares: Kemp et al. (2010), Bell et al. (2011, 2014), and Harrison et al. (2008). 

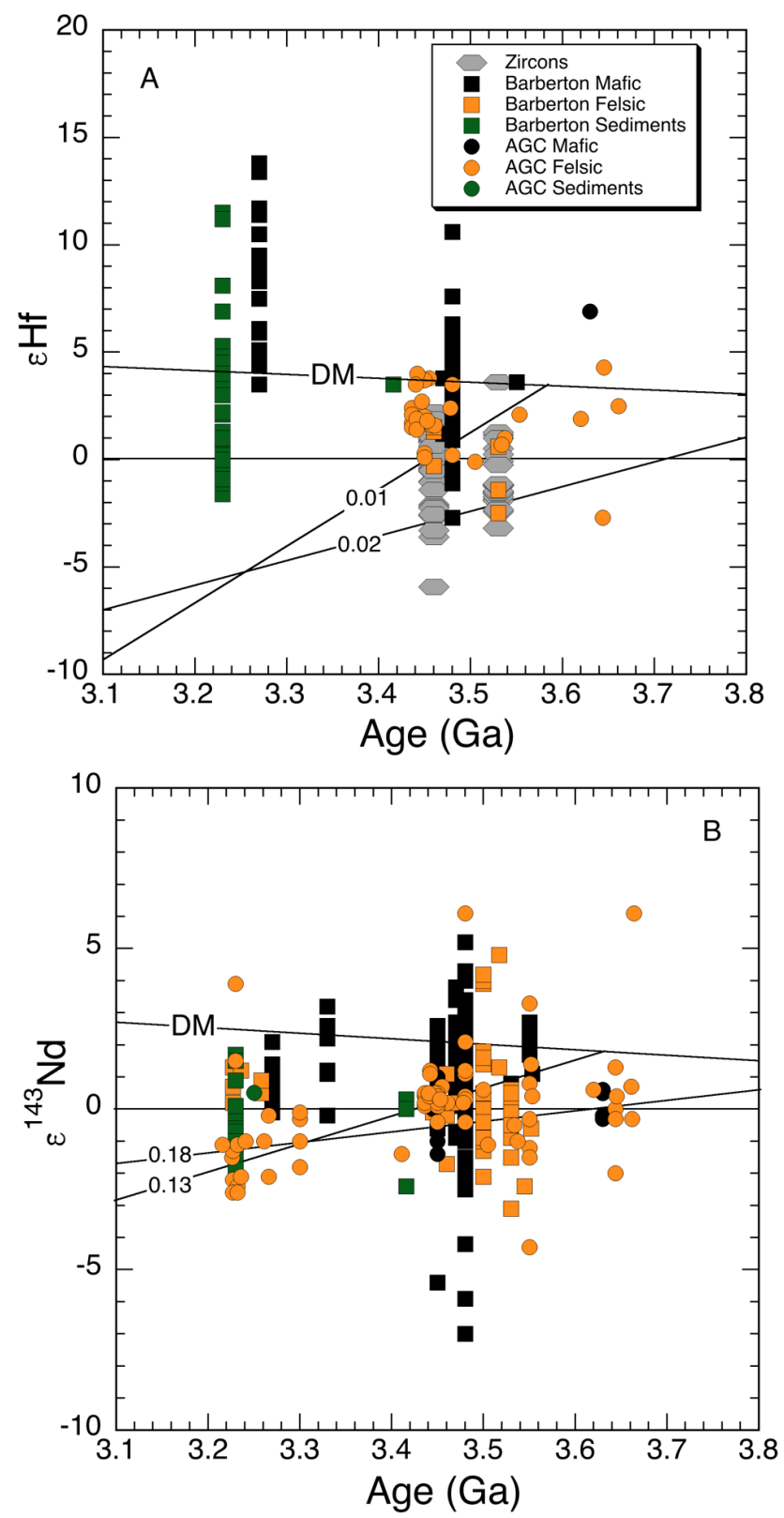

Figure 16: Initial $\varepsilon \mathrm{Hf}$ and $\varepsilon^{143} \mathrm{Nd}$ data for Paleoarchean rocks from the northeastern Kaapvaal Craton. Numbers along the lines in each diagram give the value of parent/daughter ratio $\left({ }^{176} \mathrm{Lu} /{ }^{177} \mathrm{Hf}\right.$ and $\left.{ }^{147} \mathrm{Sm} /{ }^{144} \mathrm{Nd}\right)$ corresponding to the slope of those lines. The evolution lines for the less evolved composition $\left({ }^{176} \mathrm{Lu} /{ }^{177} \mathrm{Hf}=0.02\right.$ and ${ }^{147} \mathrm{Sm} /{ }^{144} \mathrm{Nd}=0.18$ ) extrapolate back to a model age of $4.1 \mathrm{Ga}$. The other lines start from depleted mantle (DM) isotopic composition at 3.6 Ga. Data from (Carlson et al., 1983; Kroner and Tegtmeyer, 1994; Lahaye et al., 1995; Kroner et al., 1996; Chavagnac, 2004; Caro et al., 2006; Clemens et al., 2006; Schoene et al., 2009; Furnes et al., 2012; Kroner et al., 2013; Puchtel et al., 2013; Kroner et al., 2014; BlichertToft et al., 2015; Hoffman et al., 2016; Puchtel et al., 2016; Garçon et al., 2017; Schneider et al., 2018). AGC = Ancient Gneiss Complex. 


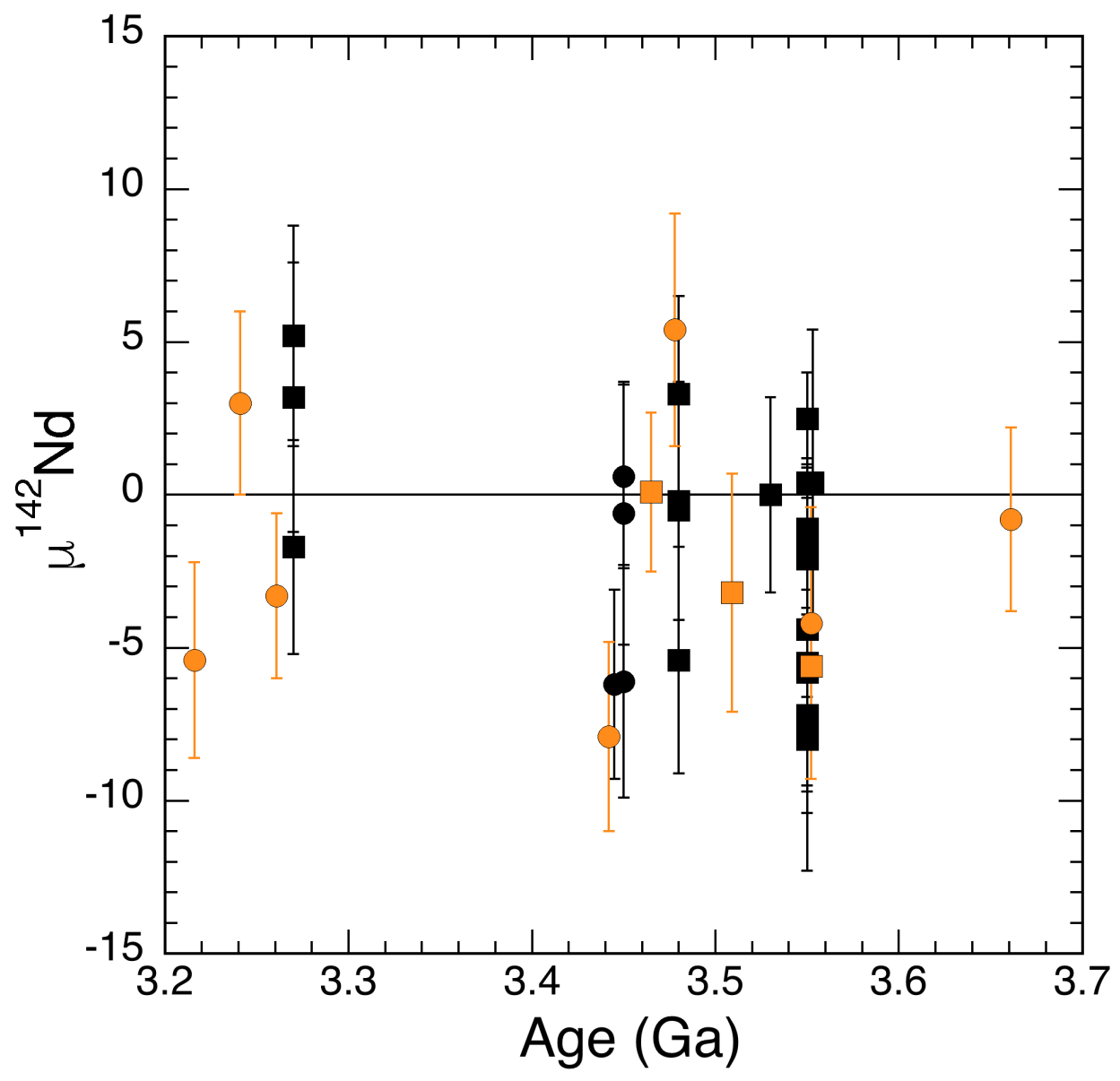

Figure 17: ${ }^{142} \mathrm{Nd} /{ }^{144} \mathrm{Nd}$ data for samples from the eastern Kaapvaal Craton. Data from (Caro et al., 2006; Puchtel et al., 2013; Puchtel et al., 2016; Schneider et al., 2018). Sample symbols correspond to those in the legend of figure 16. 


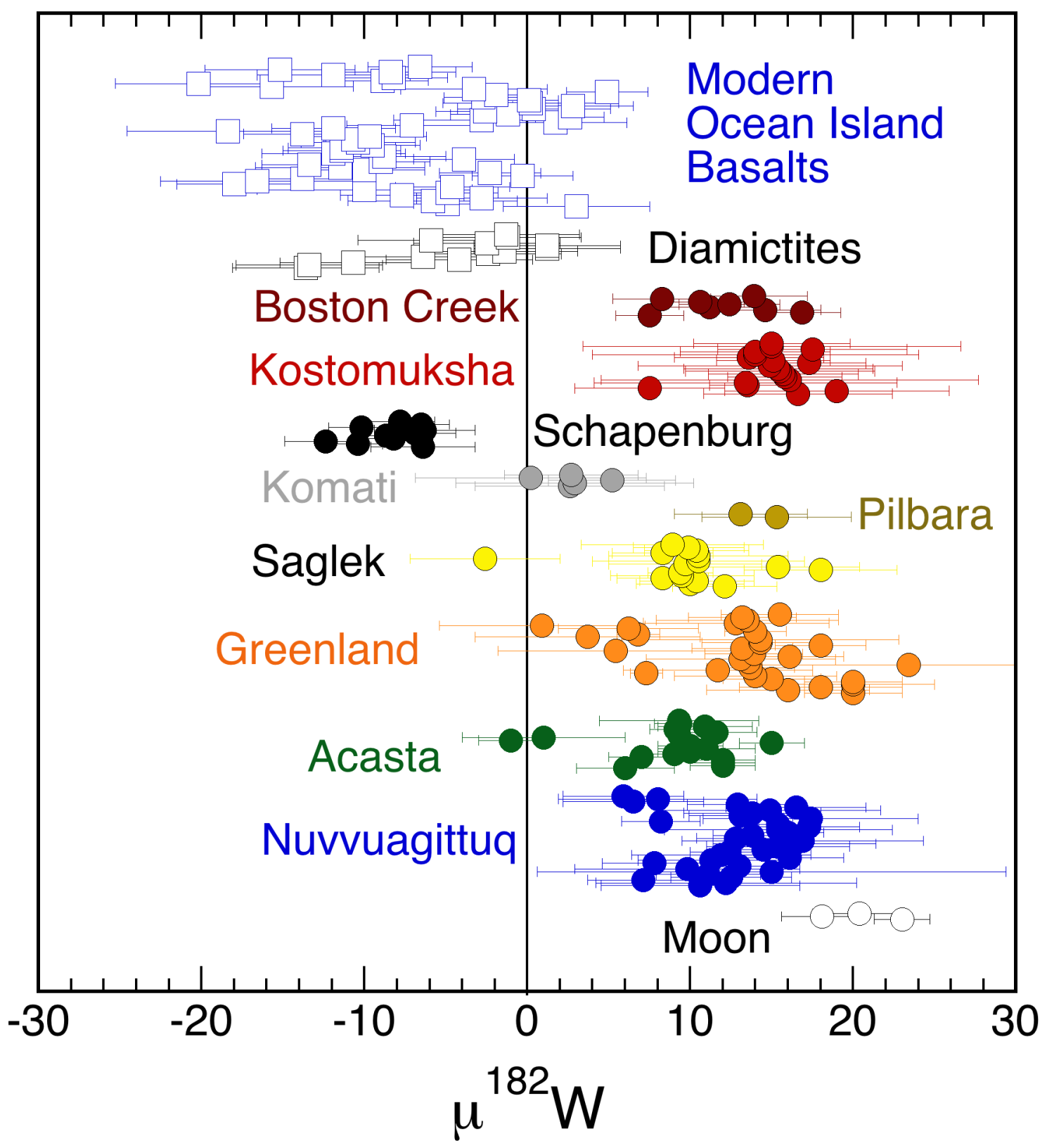

Figure 18: Range in ${ }^{182} \mathrm{~W} /{ }^{184} \mathrm{~W}$ in terrestrial rocks and lunar basalts. The data are arranged from oldest terrane (bottom) to youngest (top). Data sources: Moon (Touboul et al., 2015), Nuvvuagittuq (Touboul et al., 2014), Acasta (Willbold et al., 2015; Reimink et al., 2018), Greenland (Willbold et al., 2011; Rizo et al., 2016), Saglek (Liu et al., 2016), Pilbara (Rizo et al., 2019), Komatii and Kostomuksha (Touboul et al., 2012), Schapenburg (Puchtel et al., 2016), Boston Creek (Puchtel et al., 2018), glacial diamictites (Mundl et al., 2018), modern ocean island basalts (Liu et al., 2016; Mundl et al., 2017; Rizo et al., 2019). 

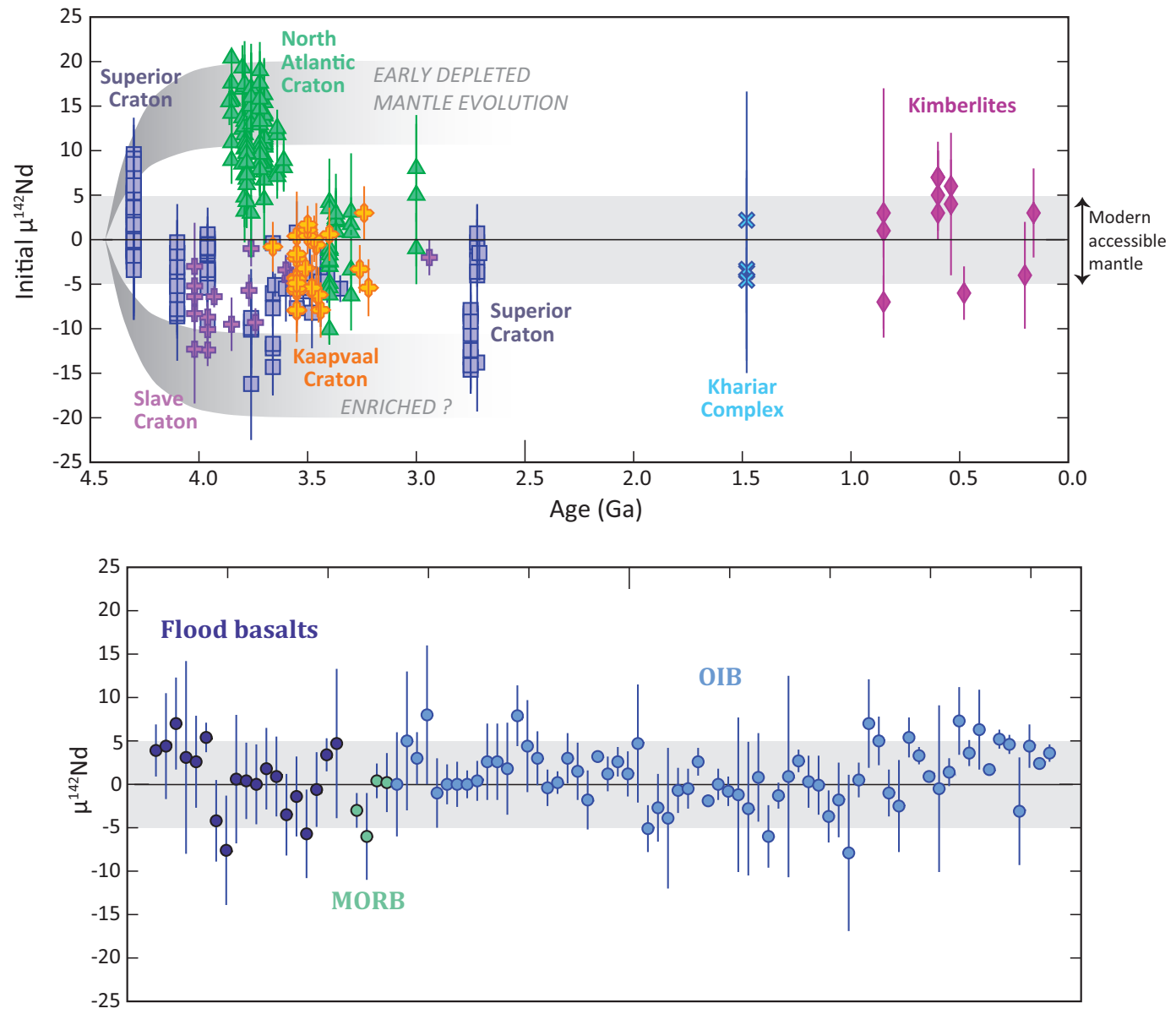

Figure 19: Evolution of ${ }^{142} \mathrm{Nd} /{ }^{144} \mathrm{Nd}$ through time in terrestrial rocks. The grey bars show the typical analytical uncertainty of the measurements. Top figure: Superior Craton comprises data from the Nuvvuagittuq Greenstone Belt, the Ukalik belt of the Inukjuak domain, and several samples from the Hudson Bay terrane. The $\mu^{142} \mathrm{Nd}$ values of the Nuvvuagittuq Greenstone Belt were recalculated and shown at both 4.3 and $4.1 \mathrm{Ga}$ to represent the initial values they would have had at those ages. The North Atlantic Craton includes data for Southwest Greenland and Northern Labrador. The Kaapvaal Craton grouping includes data for the Ancient Gneiss Complex, the Barberton Mountain Land greenstone belts, and the Schapenburg greenstone remnant. Kimberlites studied are from the Sarfatoq (Greenland), Siberia, South Africa, and the United States. Bottom figure: Flood basalt grouping includes data for the Ontong Java Plateau, Deccan Traps, and Baffin Island. Mid-ocean ridge basalts (MORB) are from the Pacific and Indian Ocean. Ocean island basalts (OIB) are from Pitcairn, Society, Iceland, Hawaii, Cook, Samoa, Galapagos, Christmas, and Reunion islands. Data sources: (Boyet and Carlson, 2006; Caro et al., 2006, 2017; Bennett et al., 2007; Andreasen et al., 2008; O'Neil et al., 2008, 2012, 2016; Murphy et al., 2010; Rizo et al., 2011, 2012, 2013, 2016; Jackson and Carlson, 2012; Roth et al., 2014; Puchtel et al., 2016; De Leeuw et al., 2017; Gautam et al., 2017; Morino et al., 2017; O'Neil and Carlson, 2017; Garçon et al., 2018; Horan et al., 2018; Peters et al., 2018; Reimink et al., 2018; Schneider et al., 2018). 